Н. Ю. Григорьев, Н. А. Мулина, В. А. Чвякин

\title{
КУЛЬТУРА И МАССОВЫЕ КОММУНИКАЦИИ
}

\author{
Учебник
}




\title{
НОВАЯ HAYKA \\ Международный центр \\ научного партнерства \\ International Center for Scientific Partnership
}

Григорьев Николай Юрьевич

Мулина Наталья Алексеевна

Чвякин Владимир Алексеевич

\section{КУЛЬТУРА И МАССОВЫЕ КОММУНИКАЦИИ}

\author{
Учебник
}

г. Петрозаводск

МЦНП «Новая наука»

2021 
УДК 316.7

ББК 76

K90

\section{Редактор:}

И. И. Ивановская

\section{Авторы:}

\section{Григорьев Николай Юрьевич,}

кандидат философских наук, доцент кафедры рекламы и связей с общественностью в медиаиндустрии, Московский политехнический университет, Москва, Россия

\section{Мулина Наталья Алексеевна,}

кандидат философских наук, доцент, заведующая кафедрой рекламы и связей с общественностью, Московский международный университет, Москва, Россия

\section{Чвякин Владимир Алексеевич,}

доктор философских наук, профессор кафедры рекламы и связей с общественностью в медиаиндустрии, Московский политехнический университет, Москва, Россия

\section{Рецензенты:}

\section{Киселев Геннадий Михайлович}

кандидат педагогических наук, доцент, Первый проректор, Московский региональный социально-экономический институт

\section{Артемьев Алексей Александрович}

кандидат философских наук, доцент кафедры информационного обеспечения,

\section{Военный университет МО РФ}

\section{Григорьев, Николай Юрьевич.}

К90 КУЛЬТУРА И МАССОВЫЕ КОММУНИКАЦИИ : учебник / Н. Ю. Григорьев, Н. А. Мулина, В. А. Чвякин. - Петрозаводск : МЦПП «Новая наука», 2021. - 143 c.

\section{ISBN 978-5-00174-217-3}

Учебник содержит сведения по основным теоретическим вопросам культуры, массовых и межкультурных коммуникаций, которые способствуют систематизации данных о методологических основаниях современной медиакультуры. Обращается внимание на возможности реализации культурологических функций применительно к условиям профессиональной деятельности специалистов в сфере массовых коммуникаций. Учебник адресован студентам по направлению подготовки магистратуры 42.04.01-Реклама и связи с общественностью.

Рекомендован Ученым советом (Сенатом) АНОВО «МОСКОВСКИЙ МЕЖДУНАРОДНЫЙ УНИВЕРСИТЕТ» дЛя использования в учебном процессе в качестве учебника для студентов по направлению подготовки 42.04.01 Реклама и связи с общественностью всех форм обучения, Протокол № 9 от 25 февраля 2021 года. 


\section{ОГЛАВЛЕНИЕ}

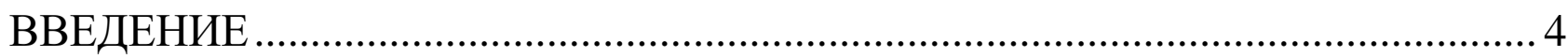

1. КУЛЬТУРОЛОГИЯ КАК НАУЧНАЯ СИСТЕМА ЗНАНИЙ .............................. 6

1.1. Возникновение, предмет и задачи культурологии.............................................. 6

1.2. Содержание культурологии и ее роль в обществе........................................ 12

1.3. Методология культурологического анализа социальных явлений............... 17

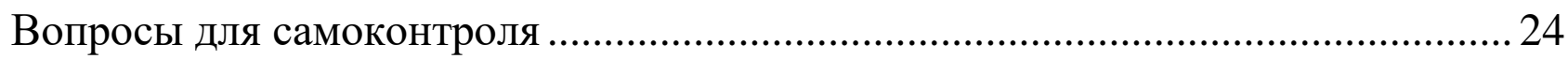

2. ОБЩЕТЕОРЕТИЧЕСКИЕ ОСНОВЫ КУЛЬТУРЫ........................................... 26

2.1. Понятие культуры: многообразие определений .............................................. 26

2.2. Содержание и закономерности развития культуры........................................ 38

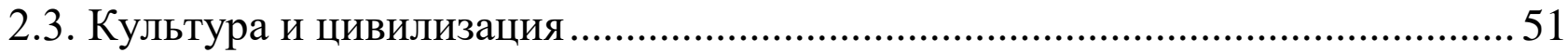

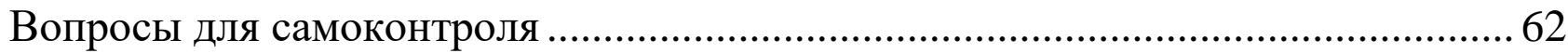

3. КУЛЬТУРА РОССИИ НА ПУТИ

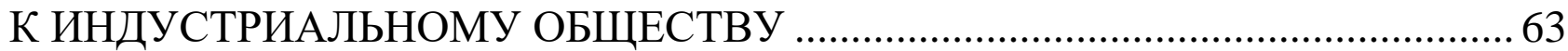

3.1. Естественно-научные источники развития российской культуры ................63

3.2. Индустриализация и культурная детерминация

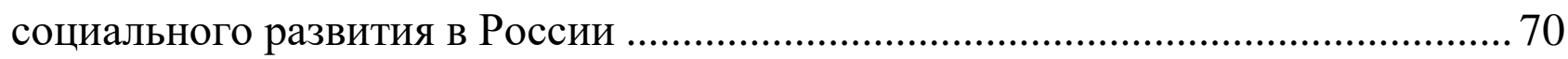

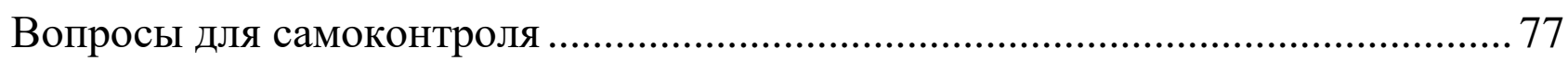

4. ФУНКЦИОНАЛЬНАЯ ОБЩНОСТЬ КУЛЬТУР

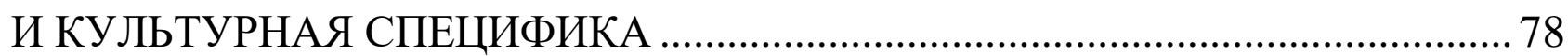

4.1. Сущность культурных ценностей и их место

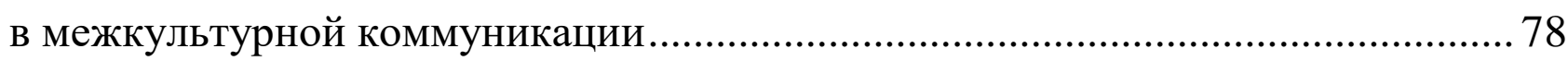

4.2. Культурная дистанция, конфликт культур и культурные традиции ............ 83

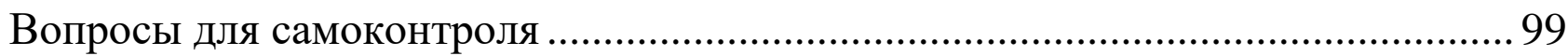

5. ДИАЛОГ КУЛЬТУР И СОЦИАЛЬНЫЕ КОММУНИКАЦИИ......................... 100

5.1. Культурная идентичность,

вторичная адаптация/социализация, инкультурация............................................. 100

5.2. Стереотипы в межкультурной коммуникации .............................................. 112

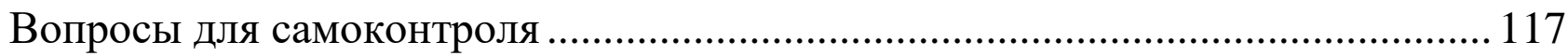

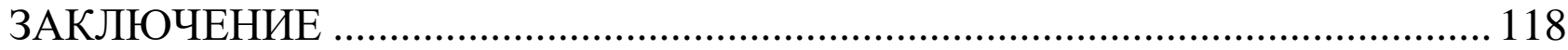

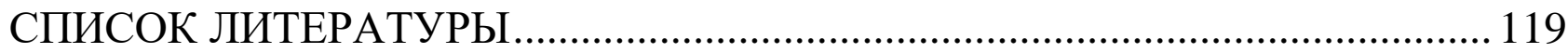

ГЛОССАРИЙ «КУЛЬТУРА И МАССОВЫЕ КОММУНИКАЦИИ» ................. 125 


\section{ВВЕДЕНИЕ}

Изучение дисциплины «Теория массовых коммуникаций» предполагает освоение достаточно большого блока вопросов по роли культуры в качестве основы межкультурных коммуникаций. Культура и массовые коммуникации имеют между собой такие соотношения, которые определяют приоритетность именно культуры в качестве одного из теоретических оснований массовых коммуникаций. Связано это с тем, что массовая коммуникация представляет собой процесс распространения информации при помощи технических средств на рассредоточенные, численно большие аудитории. Культура таких аудиторий определяет не только успешность распространения информации, но и эффективность ее восприятия. Сам процесс восприятия массовой информации зависит, с одной стороны, от базовых характеристик культуры конкретных целевых аудиторий, а с другой стороны, имеется зависимость восприятия от ситуативных характеристик культурного мировоззрения целевой аудитории.

Поэтому важно учитывать, что культура всегда присутствует в качестве одного из значимых факторов и характеристик массовой коммуникации. Если такая характеристика представляет собой пассивный контекст целевой аудитории, его можно использовать в качестве принципа ее таргетирования. Но культурная характеристика целевой аудитории может рассматриваться также и в качестве активного контекста, который предполагает возможность влияния на самые разные стороны целевых аудиторий (конструктивные или деструктивные социальные коммуникации, потребительское поведение и отношение, созидательные установки и др.).

Между культурой массовых коммуникаций и средствами массовой информации в истории всегда функционировала активная связь. Например, периодическая печать может служить тому примером. Задачи периодической печати изменялись на протяжении истории и характерным образом отражали культуру массовых коммуникаций. Так, в XVI-XVII вв. существовала авторитарная теория печати, а в XVII в. - теория свободной печати, в XIX в. 
появилась теория пролетарской печати, в середине XX в. возникает теория социально-ответственной печати. Периодическая печать с точки зрения восприятия информации является более сложной формой по сравнению с телевидением, радио и компьютерными сетями. Кроме этого, с точки зрения подачи материала, газеты менее оперативны, чем иные виды СМИ. Если анализировать успешность функционирования каналов массовых коммуникаций и эффективность восприятия массовой информации, то совершенно очевидно, что культуре в этих процессах принадлежит далеко не последняя роль. Особая роль культуры массовых коммуникаций принадлежит таким сферам деятельности, как связи с общественностью и межкультурные коммуникации. Поэтому культура должна рассматриваться в качестве методологической основы массовых коммуникаций с целью формирования компетенций, необходимых для профессиональной деятельности в системе социальных отношений. 


\section{1. КУЛЬТУРОЛОГИЯ КАК НАУЧНАЯ СИСТЕМА ЗНАНИЙ}

\section{1. Возникновение, предмет и задачи культурологии}

Культурология - одна из наиболее молодых отраслей научного знания, хотя научное исследование культуры имеет глубокие исторические традиции. Различные аспекты культуры всегда изучались археологией, этнографией, историей, психологией, социологией, философией [83]. Однако лишь в XX веке возникают первые попытки специального исследования культуры как целостного общественного явления. Время рождения культурологии как специальной науки обычно относится к концу XIX - началу XX века. В процессе возникновения данной науки можно выделить следующие этапы. Первый этап - донаучный, этап становления культурологии, который начался с периода древности и завершился в XVIII веке. На этом этапе речь не идет о культурологии как научной системе знаний, а культура как целостное общественное явление еще не сформировалась. На базе дифференциации научного знания различные отрасли науки изучают различные аспекты культуры. С середины XVIII века можно датировать начало нового этапа развития культурологии - научного, который завершается в XX веке окончательным утверждением и конституированием культурологии в качестве специальной [36]. Здесь набирает силу тенденция интеграции научного знания, гуманизации общественных отношений на базе просвещенного разума человека, понимания культуры как целостного общественного явления, как синонима цивилизации. Отсюда и возникают предпосылки для специального исследования культуры различными авторами. По мнению отечественных специалистов, появление в XX веке особого знания о культуре, претендующего на относительно самостоятельную научную систему, обусловлено:

a) осознанием спекулятивности классической «философии культуры», ее неспособности в полной мере осмыслить богатый эмпирический материал, 
потребностью выработки такого понимания культуры, которое может надежно связать теоретические представления о ней и практическое ее воплощение во всех сферах человеческой жизнедеятельности;

б) необходимостью выработки такой методологии, которая обеспечит как адекватное изучение культуры частными науками, так и их предметное единство, вытекающее из субстанционального понимания культуры;

в) стремлением к выработке общих подходов к пониманию культуры в условиях нарастания диалога различных культур, необходимостью поиска их единой природы, проявляющейся в локальном культурном многообразии;

г) важностью вопроса сравнения и соотношения разных культур, в частности, европейской и неевропейской в условиях роста национального самосознания в странах «третьего мира»;

д) необходимостью целостного, системного анализа культуры как сферы государственной политики, принятия в ней всесторонне обоснованных управленческих решений;

е) необходимостью формирования культурных потребностей человека и их удовлетворения в потребительском обществе, обоснования успешной экономической деятельности в сфере массовой культуры;

ж) тревожным ростом технократизма, рационализма, вызванным новым витком научно-технического прогресса, осознанием важности гуманитарного «противовеса» для сохранения стабильности существования человека, а также стремлением компенсировать культурологией все еще существующее состояние преждевременной и узкой профессионализации [42].

Одним из первых культурологов мира считается английский этнограф и историк первобытной культуры Э.Б. Тайлор (1832-1917). Будучи одним из основоположников эволюционизма, он исходил из идеи культурного единства человечества и его прогрессивного развития от низших форм к высшим [77]. Э.Б. Тайлор полагал, что каждый элемент культуры эволюционирует независимо от других, а вместе они составляют историю общества. Э.Б. Тайлор 
рассматривал развитие культуры по аналогии с естественно-историческим процессом. При этом основу культурного развития составляет саморазвитие идей - религиозных, научных, технических и т.п. В своем фундаментальном труде «Первобытная культура» (1871) он уделил основное внимание рассмотрению ранних форм религии и мифологии. Развитие религии он представлял в виде однолинейной эволюции от дорелигиозной эпохи через политеизм к монотеизму. Основоположником культурологии, который одним из первых предпринял попытку введения данного термина в научный оборот и построения общей теории культуры, был американский культур антрополог Л.А. Уайт (1900-1975). Именно он положил начало использованию термина «культурология» в качестве синонима науки о культуре. Разработку основ данной науки Уайт осуществил в своих специальных трудах - «Наука о культуре» (1949), «Эволюция культуры» (1959) и «Понятие культуры» (1973). В них он выдвинул и обосновал ряд общетеоретических положений культурологии, а также связал исследование культурологических проблем с проблемами человека [78]. Главную задачу культуры и культурологии ученый видел в формировании, просвещении и возвышении человека. Культурология в современном ее понимании постепенно формируется, выходя из-под родительской опеки философии, обретая собственный предмет исследования и обосновывая соответствующие ему методы постижения культуры. По вопросу о предмете культурологии в настоящее время пока еще нет однозначной позиции. В частности, сегодня имеют место трактовки культурологии:

- как философской науки о культуре;

- как исторической хронологии культурных достижений на различных этапах ее развития;

- как совокупности знаний о развитии и достижениях человеческой цивилизации и ее различных очагов;

- как знания о принципах и нормах, ценностях и ориентирах человеческого поведения в обществе; 
- как знания об основных проблемах, этапах развития и достижениях художественно-эстетического творчества людей;

- как комплекса научных дисциплин, изучающих все богатство культуры.

К настоящему времени можно вполне определенно говорить о культурологии как относительно самостоятельной учебной дисциплине, которая представляет собой систему социально-гуманитарных научных знаний о проблемах и закономерностях возникновения, развития и функционирования культуры. При этом считаем необходимым указать на следующие основные особенности предмета культурологии [41]. Во-первых, собирательный, интегративно-синтетический характер культурологии. Речь идет о том, что культурологическое знание формируется на базе достижений ряда других наук, изучающих различные стороны и аспекты культуры. Таковыми прежде всего являются история, археология, социология, философия, этнография, антропология, этика, эстетика и другие социально-гуманитарные дисциплины. Объединяя, интегрируя достижения указанных наук в изучении культуры, культурология формирует целостное, системное научное знание о культуре, которое не сводится к механической сумме достижений других наук. Она, таким образом, изучает культуру как целостное, системное, сложное и многогранное общественное явление. Во-вторых, важной особенностью культурологии является ее гуманитарный характер и нравственногуманистическая направленность предмета. Поскольку культура по своей природе социальна и гуманистична, постольку культурология является социально-гуманитарной дисциплиной. Центральной проблемой культурологии является проблема формирования человека. Ведь человек есть высшая ценность, главное производное, средоточие и цель развития культуры. Смысл и назначение культуры и науки о ней состоит в возделывании, просвещении и формировании человека, который, в свою очередь, выступает главным творцом культурных ценностей. Одновременно задача культурологии состоит и в том, чтобы дать качественную культурологическую оценку различных элементов 
общественного организма - экономики, политики, морали, права, религии, искусству и т.п. И потому предметом культурологии выступает не только культура в целом, но и ее различные общественные типы, конкретные виды, формы и способы деятельности людей. В-третьих, особенностью предмета культурологии является историческая ретроспективность, преимущественная обращенность ее к культурному наследию прошлого. Конечно, развитие культуры осуществляется от прошлого, через настоящее к будущему. Однако основные ценности культуры - это преимущественно ценности прошлого, прошедшие испытание временем и переданные нам всеми предшествующими поколениями. Вот почему, чем древнее культура, тем она ценнее и привлекательнее. В то же время ценностям настоящего времени надо еще выдержать испытание на культурность хотя бы в рамках жизни одного поколения.

Между тем, основная масса непреходящих ценностей культуры была создана, сохранена и передана нам из прошлого. Поэтому важной частью предмета культурологии является глубокое изучение истории возникновения и развития культуры (мировой и отечественной), основных этапов ее развития, исторических типов, форм и разновидностей. Наконец, в-четвертых, специфической чертой предмета культурологии является высокая роль художественно-эстетического начала в ее содержании. Конечно, совокупная культура не сводится только к процессу и результатам художественного творчества. И культурология не может пониматься лишь как наука об искусстве. Такой наукой выступает эстетика. Но нельзя не признать, что в сфере художественного творчества создаются высшие ценности культуры в целом. Именно в этой сфере наиболее зримо проявляется творческая одухотворенность культурно-исторического процесса. Поэтому художественноэстетическое содержание в культуре и культурологии нельзя игнорировать и недооценивать. При этом, повторяем, культурология не подменяет своим предметом эстетику как науку о закономерностях развития искусства. Она 
лишь использует ее наиболее общие выводы для собственного обогащения, завершения и, если хотите, - заострения своего предмета художественным началом. Без этого начала было бы трудно понять природу самой культуры, понятие которой, по меткому замечанию Н.А. Бердяева, восходит к символике культа [8].

Таким образом, можно заключить, что культурология представляет собой целостную, системно-интегративную отрасль социально-гуманитарного знания о предпосылках возникновения, закономерностях развития, формах проявления и способах функционирования культуры общества и человека в прошлом и настоящем времени. 


\section{2. Содержание культурологии и ее роль в обществе}

Представить содержание культурологии - это значит раскрыть всю совокупность составляющих ее элементов, в которых полнее и конкретнее раскрывается ее предмет. Правильное понимание содержания культурологии позволяет системно и упорядоченно изучать эту науку. Учитывая предмет культурологии и ее характерные особенности, содержание этой научной дисциплины можно системно представить в целостной совокупности четырех основных и взаимосвязанных сторон (блоков) [38]. Первая сторона методологическая, или общетеоретическая. Иногда eе называют и философской. Она включает в себя блок проблем, связанных с общим пониманием предмета культурологии, основных этапов ее становления и развития, характерных особенностей ее содержания, а также общих задач и роли в обществе. Кроме того, сюда также входит и проблема общетеоретических основ самой культуры как центральной и основополагающей категории культурологии. Это, в частности, вопросы сущности и содержания культуры, закономерностей ее развития и роли в обществе. Здесь речь идет о культуре как общественном явлении в целом, безотносительно к ее национально-историческим формам. Вторая сторона историческая. Она включает социодинамику культуры, т.е. историю ее возникновения и развития с древнейших времен до наших дней. Здесь модно выделить два основных направления - историю мировой культуры и историю отечественной культуры. В истории мировой культуры целесообразно сосредоточить внимание на основных этапах развития западной культуры (европейской и американской) и особенностях развития восточной культуры. Затем на историческом фоне взаимодействия западной и восточной культур представляется возможным глубже рассмотреть основные этапы развития, особенности и достижения отечественной, российской культуры. Третья сторона содержания культурологии - функциональная. Здесь основное внимание сосредотачивается на изучении основных форм проявления культуры 
в современной деятельности человека и общества. Совокупность проблем этого блока можно кратко озаглавить так: «Культура - общество - человек». Сюда входят все социокультурные проявления общественной жизнедеятельности, в частности, проблемы политической, экономической, социальной и духовной культур, а также вопросы профессиональной культуры, культуры мышления и поведения, общения и взаимоотношений, труда и досуга, семейно-бытовых отношений и т.п. Нетрудно заметить, что в каждой из перечисленных проблем можно вычленить два основных аспекта: культурно-общественный и культурно-личностный. Такая постановка позволяет заострить внимание на задачах формирования тех или иных элементов культуры как в обществе в целом, так и применительно к каждому человеку. Четвертая сторона художественно-эстетическая. Она завершает рассмотрение культурологической проблематики, заключает ее. Здесь, конечно, культурология смыкается с эстетикой как наукой о закономерностях и видах искусства, отражения мира по законам красоты. И это правильно, потому что все-таки высшие ценности культуры и «души прекрасные порывы» имеют место именно в художественноэстетической сфере. Здесь культура и изучающая ее культурология как бы находят свое заострение и завершение. Поэтому в курсе культурологии нельзя обойти вниманием общие закономерности и разновидности художественного творчества, механизм отражения мира с позиций прекрасного, возвышенного, трагического и комического, а также вопросы культурно-эстетического образования и воспитания личности. Без рассмотрения названных вопросов нельзя глубоко понять существо культуры, символику и привлекательность культурных ценностей, их роль в формировании человека.

Следует отметить, что в большинстве учебных пособий по культурологии наиболее глубоко и широко представлены первые две стороны ее содержания. Что же касается двух последних ее сторон, то во многих пособиях они или отражены частично, или вообще не находят отражения. Это, на наш взгляд, серьезно обедняет содержание культурологии и неблагоприятно сказывается на формировании студентов как будущих специалистов-профессионалов. В ряде 
учебных пособий культурология вообще излагается как история мировой и отечественной культуры. Такое изложение предмета культурологии также трудно признать правомерным. Оно страдает односторонностью, методологической узостью, недостатком мировоззренческих выводов и обобщений. Итак, в содержание культурологии с позиций понимания ее предмета и особенностей входит решение следующих основных задач [33]:

- разработка методологических основ культурологии, четкое определение ее предмета, содержания и структуры, а также основных этапов ее становления и развития в культурологических концепциях;

- выявление общих закономерностей возникновения, развития, содержания и механизма функционирования культуры в целом;

- рассмотрение исторических этапов, традиций и особенностей, достижений и тенденций развития мировой культуры;

- анализ исторических этапов становления и развития, характерных особенностей и высших достижений отечественной культуры;

- исследование современных форм проявления культуры как специфического способа жизнедеятельности общества и человека, в том числе и вопросов профессиональной культуры будущих специалистов;

- анализ общих закономерностей и особенностей художественной культуры, механизма и разновидностей эстетического творчества;

- характеристика социальной роли культуры в обществе, анализ проблем культурно-эстетического образования и воспитания личности с учетом ее профессиональных задач.

Социальная роль культурологии выражается в воздействии ее содержания на развитие общества и каждого человека. Конкретно это воздействие проявляется в социальных функциях культурологии, т.е. магистральных направлениях влияния ее предмета и содержания на развитие общества и человека. Таких основных функций можно выделить несколько. Познавательная функция. Она выражается в том, что культурология обогащает 
человеческие знания всей проблематикой своего предмета и содержания. При этом в содержании культурологии имеют место не только общекультурологические знания, но и специально-профессиональные. Таковыми, к примеру, выступают вопросы политической, правовой и экономической культуры, необходимые для формирования специалистов в области управления, международных отношений, юриспруденции и экономической деятельности. Аксиологическая (оценочная) функция. В процессе изучения культурологии человек постигает систему ее категорий, принципов, теорий и взглядов, которые позволяют ему правильно оценивать социальные факты, явления и процессы с позиций культуры. Не каждый человек может различить, что культурно, а что некультурно в сложной системе общественных отношений, хотя каждый человек склонен к ориентации именно на культурное [40].

Изучение культурологии формирует методологические критерии демаркации, разграничения культуры и антикультуры в жизнедеятельности общества и человека. Формирующая (воспитательная функция) культурологии выражается в том, что в процессе ее изучения студенты приобщаются к непреходящим ценностям мировой и отечественной культуры, постигают принципы и нормы культурной жизни, формируют убеждения и взгляды, идеалы и принципы достойного поведения и общественно полезной деятельности, вырабатывают навыки и умения профессиональной культуры управленческой, правовой, экономической и иной. Изучение культурологии так или иначе возделывает человека, возвышает его духовно, интеллектуально и нравственно. Регулятивная функция культурологии состоит в том, что ее категориальный аппарат выступает инструментом регулирования человеческого поведения и деятельности. По своему содержанию, смыслу и назначению категории культурологии в ценностном аспекте выступают как нормы и правила, идеалы и принципы человеческого поведения. 
Усвоение культурологических знаний позволяет человеку, во-первых, управлять собой, регулировать свое поведение, а, во-вторых, вырабатывать умения и навыки правильного управления другими людьми [37]. В частности, глубокое усвоение культурологического потенциала формирует гуманнодемократический стиль управленческой деятельности. Конструктивнотворческая функция культурологии проявляется в том, что она способствует повышению интеллектуальных возможностей, обогащению фантазии и творческих способностей человека. Ведь все ценности культуры и культурологические знания по своей природе символичны, одухотворены и облагорожены созидательно творческой деятельностью человека. А потому культурология и культура составляют созидательную инфраструктуру и творческую среду, необходимую для новаторства во всех видах профессиональной деятельности. Сегодня профессионал - это не только глубокий знаток своего дела, но и культурно развитая личность.

Современные представления о целях и задачах вузовского образования исходят из необходимости обеспечить гуманизацию этого процесса, дающую возможность молодежи глубоко овладеть достижениями мировой и отечественной культуры, стать широко образованными и культурными специалистами-профессионалами. Такой подход диктуется также задачами реформирования системы столичного образования в России, потребностями подготовки квалифицированных профессионалов государственной и муниципальных служб московского мегаполиса. Речь идет о новой философии образования, в которой цели профессионального обучения органически соединяются с задачами культурно-эстетического развития личности [25]. 


\section{3. Методология культурологического анализа социальных явлений}

Культурология, как уже отмечалось, - сравнительно молодая наука. До сих пор еще не угасли споры о ее предмете и содержании. Тем не менее, настало время рассмотрения проблемы методов культурологического анализа общественных явлений. Понятие «методология» применительно к культурологии означает, во-первых, общее учение о методах познания и преобразования действительности, о применении общетеоретических принципов культурологии к познанию культуры и практической деятельности человека в культурной области. Во-вторых, под методологией понимается система методов культурологического анализа общественных явлений и процессов [39]. В понятии метода выражается способ, путь исследования, выступающий как совокупность приемов, операций и процедур познавательной деятельности в соответствии с природой изучаемого объекта, результатом использования которых является постижение истины. В данном отношении речь идет о том, как надо исследовать культуру, чтобы она открыла нам свои тайны. Содержание методологии культурологического анализа в значительной степени зависит от понимания объекта и предмета исследования культурологии, поскольку культуру изучают многие другие науки. Оно обусловлено также и тем, как понимается и трактуется само понятие культуры. Наконец, методология культурологического анализа содержит и общеметодологические принципы, и подходы, применяемые в других отраслях научного знания. Среди них выделяются всеобщие, универсальные принципы философского анализа и общенаучные методы теоретического и эмпирического анализа культурологических явлений. Следует заметить, что культурологический анализ общественных явлений отличается от социокультурного анализа, применяемого в социальной философии [46]. Социокультурный подход выступает одним из элементов методологии социально-философского анализа общественных явлений. Раньше, когда 
культурология в России не имела самостоятельного научного статуса и специально не изучалась, данный вопрос не имел научного смысла [29].

В настоящее время культурология обрела научную самостоятельность, и потому существует необходимость в обосновании методологии культурологического анализа. Конечно, методология культурологического анализа не может игнорировать пласт общих подходов и принципов, обоснованных философией как всеобщей методологией, в том числе и прежде всего - социальной философией. Более того, в социальной философии на уровне частных концепций существует и развивается философия культуры, которая одновременно выступает и частью культурологии. Однако в культурологии как научной дисциплине, в отличие от философии культуры, акценты смещены с понимания культуры в общем и целом на изучение ее в определенных пространственно-временных границах, на описание и объяснение ее конкретных форм с опорой на конкретный эмпирический материал. Это значит, что культурологический анализ предполагает использование не только общих и общенаучных, но и специальных, особенных методов исследования культуры.

Методология культурологического анализа включает в свое содержание четыре взаимосвязанные группы методов, подходов и принципов: общие подходы и принципы, социально-гуманитарные подходы, общенаучные методы и специальные методы изучения культуры. Рассмотрим их более подробно. Прежде всего, культурология использует совокупность всеобщих принципов познавательной деятельности, обоснованных философией. Таковыми выступают принципы развития, всеобщей связи, познаваемости, детерминизма, противоречивости, единства качественной и количественной определенности, поступательности, преемственности и цикличности культурных явлений и процессов [44]. Принцип развития предполагает рассматривать культуру в постоянной динамике и изменчивости. Принцип всеобщей связи ориентирует исследователя на всесторонность анализа, памятуя о многообразии 
взаимосвязей между различными явлениями и процессами культуры. Принцип познаваемости формирует оптимизм и активную позицию исследователя при анализе культурных явлений. Принцип детерминизма указывает на выявление обусловленности, цепи причинно-следственных связей в развитии культуры и ее элементов. Общеметодологическую роль для культурологии имеют также философские принципы, обусловленные действием объективных и всеобщих законов развития - закона взаимодействия противоположностей, закона взаимоперехода количественных и качественных изменений и закона отрицания отрицания.

Методология культурологического анализа включает в себя также группу методов и подходов социально-гуманитарного содержания [34]. К ним относятся цивилизационный, исторический и аксиологический подходы, системно-структурный анализ, функционально-деятельностный подход, социально-типологический, логический и феноменологический, социологический и психологический подходы и методы изучения культуры. Названные подходы и методы получили обоснование в социальной философии и других отраслях социально-гуманитарного знания - истории, социологии, политологии, психологии и т.п. Так, системно-структурный анализ позволяет представить культуру, с одной стороны, как целостную, динамическую и открытую систему, а с другой, — как совокупность взаимосвязанных элементов — науки, искусства, морали, права, религии, языка и т.п.

Функционально-деятельностный подход позволяет исследователю рассмотреть культуру как сложный процесс творческой деятельности человека и общества по созданию, сохранению, накоплению, распространению и потреблению культурных ценностей. Исторический подход предполагает анализ достижений культуры на различных этапах исторического развития государств и народов. Аксиологический подход делает акцент на ценностное содержание культуры, как совокупности многообразных ценностей. 
Феноменологический подход ориентирует на анализ различных форм проявления культуры в прошлом и настоящем времени [88].

Кроме указанных групп методов, культурологический анализ предполагает применение группы общенаучных методов познания культуры, которые делятся на теоретические и эмпирические методы познания. Среди общенаучных теоретических методов культурологического познания выделяются: анализ и синтез, индукция и дедукция, обобщение и конкретизация, сравнение и абстрагирование и т.п. Группа общенаучных эмпирических методов включает в себя наблюдение, эксперимент, моделирование. Названные методы широко применяются в различных отраслях научного познания, в том числе и в культурологии.

Так, сегодня стало популярным применение компаративного метода сравнения различных типов и видов культур по какому-либо основанию, признаку. К примеру, плодотворным в культурологии стал «диалог» культур Запада и Востока, позволяющий глубже понять специфику нашей, отечественной культуры в рамках этого сравнительного анализа. Обобщение характерных черт различных культур приводит к их классификации различению типов и видов. Широко стало использоваться также моделирование — описание или прогнозирование различных цивилизационных, региональных, национальных, государственных и иных моделей культуры разных народов и исторических периодов. Наконец, методология культурологического анализа содержит и группу специальных подходов и методов, характерных преимущественно для культурологии и обусловленных особенностями ее предмета и содержания. Среди них следует прежде всего выделить культурантропологический, художественно-эстетический, собирательноинтегративный, знаково-символический, авторско-биографический и некоторые другие подходы и методы [68].

Культурантропологический подход неразрывно связан с центральной проблемой культурологии - проблемой человека. В данном подходе 
закономерно выражается гуманистическая природа предмета и содержания культурологии, ее функциональная направленность на формирование воспитание, просвещение и образование человека. Речь идет о том, что человек есть высшая мера культурологической оценки и анализа всех общественных явлений. Человеческое измерение, соответствие природе и назначению человека является исходным и завершающим в методологии культурологического анализа. Этот принцип на донаучном уровне был интуитивно «нащупан» еще в эпоху глубокой древности. В дальнейшем его смысл и содержание лишь углублялись и обогащались. В культурологии всегда было, есть и будет общепризнанным правило: культурно то, что гуманно, что возвышает человека и формирует его. И наоборот: все, что противоречит человеческой природе, не может претендовать на культурность [61].

Так, не выдерживают оценки на культурность, некоторые современные телевизионные проекты и программы - «Слабое звено», «Алчность», «За стеклом» и другие, поскольку они не возвышают, а опускают; не сплачивают, а разъединяют; не просвещают, а обедняют человека. Художественноэстетический подход также характерен для методологии культурологического анализа. Ранее уже отмечалось, что художественно-эстетическое начало и содержание являются характерной особенностью предмета культурологии. Эта особенность закономерно выражается в соответствующем подходе к анализу и оценке общественных явлений в культурологии. Указанный подход предполагает рассматривать явления культуры в неразрывной связи с такими понятиями, как прекрасное, гармоничное, совершенное, возвышенное. Речь идет о том, что основное содержание культурных ценностей составляют достижения художественной культуры. Именно в них наиболее полно и ярко воплощается духовно-творческая природа культурно-исторического процесса, благодаря которой культурные ценности обретают символику культа, т.е. становятся объектом почитания, преклонения, подражания. 
Культурное всегда духовно, совершенно и гармонично, поскольку в нем, по меткому выражению А.С. Пушкина, заложены «души прекрасные порывы». Поэтому оценка и анализ культурологических явлений всегда предполагают наличие художественно-эстетического измерения. Значительную роль в методологии культурологического анализа играет собирательно-интегративный подход. В нем выражается такое качество культуры, как целостное единство многообразия. Культура исключительно сложна и многогранна по своему содержанию, а потому она так или иначе является объектом изучения многих наук социально-гуманитарного профиля. Каждая из них поставляет богатый эмпирический материал для культурологии. Последняя, в свою очередь, собирает, оценивает, перерабатывает и интегрирует культурно-исторический материал в единую целостность, называемую культурой. Поэтому каждый культуролог должен умело использовать собирательно-интегративный подход к исследованию культуры, т.е. понимать роль и место каждого отдельного элемента в общей системе культурных ценностей [54].

Важное значение в культурологическом анализе имеет знаковосимволический подход к изучению культуры. Некоторые авторы называют его семиотическим. Речь идет о том, что при анализе культурных ценностей важно не только их содержание, но и форма - выражение, обозначение, красота, привлекательность. Потому и культура в целом ведет свое начало от символики культа. Культура всегда символична, т.е. наглядно образна, ритуальна и привлекательна, поскольку содержит в себе целесообразное единство глубокого гуманистического содержания и совершенных форм выражения. В культурологии XX века не зря возникло и развивается отдельное концептуальное направление - символизм. В сфере художественного творчества, как известно, также достаточно заметно представлено это направление. И это не случайно. В феноменологическом плане мир культуры - это еще и мир смыслов, знаков, ритуалов, форм проявления и восприятия культурных ценностей, нас окружающих. И поскольку такова природа 
культуры, постольку каждый исследователь должен иметь это в виду, т.е. анализировать ценности культуры с позиций знаково-символического подхода.

Методология культурологического анализа включает в себя также и авторско-биографический подход к исследованию культурно-исторических ценностей. Все культурные ценности созданы творцами - авторами, которые воплотили в них величие своего духа, красоту мироощущения, индивидуальнонеповторимое восприятие окружающего нас мира. За каждой культурной ценностью стоит автор, живший в конкретных исторических условиях и отразивший в своем творчестве духовную ситуацию этого времени. И потому изучение культуры невозможно без знания исторических личностей как творцов культурных ценностей. Такова система методов, принципов и подходов культурологических исследований. Применение их в познании культуры должно носить комплексный характер, обусловленный взаимодействием всех групп указанных методов. В то же время для применения каждого метода или подхода характерны свои конкретные методические приемы, операции, процедуры. Таковыми могут быть, например, приемы описания, объяснения, рассказа, демонстрации, чтения текстов и т.П. Они постоянно и активно применяются в процессе изучения культурологии [45].

Таким образом:

1. Культурология является относительно молодой отраслью научного знания, которая окончательно конституировалась и обрела свой предмет лишь в XX веке. Предметом ее изучения являются общие и специфические закономерности возникновения, развития и функционирования культуры в прошлом и настоящем времени. Важнейшими особенностями предмета культурологии являются собирательно-интегративный характер, ретроспективность, нравственно-гуманистическая направленность и художественно-эстетическое содержание.

2. Содержание культурологии как научной дисциплины включает четыре основных блока проблем: общетеоретические, методологические основы 
предмета; проблемы истории мировой и отечественной культуры; современные формы проявления культуры общества и человека; вопросы влияния художественной культуры на формирование всесторонне развитой личности. Социальная роль культурологии в обществе проявляется в eе основных функциях — познавательной, воспитательной, регулятивной, конструктивнотворческой и практической.

3. Методология культурологического анализа общественных явлений представляет собой систему - целостную совокупность общефилософских, социально-гуманитарных, общенаучных и специальных методов, принципов и подходов исследования культурологических проблем и форм проявления культуры. Специальными подходами культурологического анализа выступают культурантропологический, художественно-эстетический, собирательноинтегративный, знаково-символический и авторско-биографический подходы к исследованию явлений и процессов культуры.

\section{Вопросы для самоконтроля}

1. Каковы основные предпосылки возникновения и становления культурологии как относительно самостоятельной системы знаний?

2. Кто из ученых явился основоположником культурологии?

3. Чем можно объяснить разнообразие позиций относительно предмета культурологии?

4. Раскройте характерные особенности предмета культурологии как научной системы знаний.

5. Какие основные стороны и блоки проблем включает в себя содержание культурологии?

6. Перечислите основные задачи культурологии, обусловленные ее предметом и содержанием.

7. Раскройте основные функции культурологии, в которых выражается ее социальная роль. 
8. Что понимается под методологией культурологического анализа общественных явлений?

9. Раскройте специальные методы и подходы культурологического анализа. 


\section{2. ОБЩЕТЕОРЕТИЧЕСКИЕ ОСНОВЫ КУЛЬТУРЫ}

В данной главе культура рассматривается в общетеоретическом плане, как общественное явление, безотносительное к ее историческим этапам развития и национальным формам. Это прежде всего философия культуры, в которой речь идет о наиболее общем ее понятии, содержании и структуре, закономерностях развития и основных тенденциях функционирования.

\section{1. Понятие культуры: многообразие определений}

Культура — исключительно сложное, многогранное и многообразное общественное явление. А потому и отражающее ее понятие сложно и многозначно. Многие ученые пытались дать свое определение культуры. К нынешнему времени количество определений культуры уже исчисляется четырехзначными числами. И это не случайно, поскольку в огромном богатстве культуры каждый автор может найти свой существенный аспект и зафиксировать его в определении. Различные определения культуры предлагаются и разными науками - историей, психологией, педагогикой, социологией, археологией, философией. Кажется, что о культуре вообще, в том числе и культуре различных видов деятельности сказано и написано немало. Однако при специальном обращении к данной проблеме приходится констатировать, что понятие культуры пока еще рассматривалось недостаточно глубоко [48].

Достаточно широко распространен тезис о том, что в плане культурности можно ограничиться рассмотрением лишь нравственных аспектов человеческой деятельности. Такой подход методологически неприемлем в силу его очевидной ограниченности. Представляется справедливым замечание А.С. Кармина о том, что «культура — не просто слово обыденного языка, а одно из фундаментальных научных понятий социально-гуманитарного 
познания, которое играет в нем такую же важную роль, как понятие массы — в физике или наследственности — в биологии». Этим понятием характеризуется многогранный фактор человеческого бытия, который проявляется во множестве самых разнообразных феноменов социальной жизни, и составляет их общую основу.

В разные эпохи понимание культуры существенно различалось: в эпоху древности культура означала возделывание и обработку прежде всего земли; в средние века выступала как поклонение, почитание, культ на религиозной основе; в эпоху Просвещения — как воспитание, образование и просвещение. Небезынтересно отметить период европейской истории, когда понимание культуры особенно тесно смыкалось с правом. XVII век в социальной философии был эпохой господства «юридического мировоззрения», суть которого состояла в интерпретации всех связей и отношений людей в обществе в первую очередь как отношений правосубъектов: общества — как системы законодательства и организации власти, а человека - как гражданина, носителя прав, свобод и обязанностей. Если учесть, что содержание культуры крайне разнородно и включает в себя материальные, духовные, и художественные разновидности человеческой деятельности; ее процессы, продукты, проявления в самом человеке, то станет понятным, почему культура изучается самыми разными науками. Однако это приводит к тому, что этнограф и социолог, психолог и технолог, искусствовед и педагог смотрят на культуру разными глазами и видят в ней разное, по-разному ее определяют. Еще в 50-е гг. ХХ-го века А. Кребер и К. Клакхон, анализируя только лишь американскую культурологию, приводили цифру — 237 дефиниций (определений) культуры. А вышедшая двадцать лет спустя «Теория культуры» Д. Каплана и Р.А. Меннерса показала, что это число может быть еще большим. Об этом же свидетельствуют и обобщающие издания зарубежных культурологов [50].

В отечественной литературе готовность сопоставить различные дефиниции культуры позволила Л.Е. Кертману насчитать более 400 
определений. Отечественные исследователи неоднократно предпринимали попытки сгруппировать существующие подходы к определению культуры. В частности, А.С. Карминым среди таких подходов выделены описательные, антропологические, ценностные, нормативные, адаптивные, исторические, функциональные, семиотические, символические, герменевтические, идеационные, психологические, дидактические, социологические9. Представители ростовской школы культурологов выделяют ценностный (аксиологический), дезаксиологический, семиотический, информационный, гуманистический, технологический и иные подходы. В обстоятельной монографии П.С. Гуревича рассмотрено более десятка определений культуры [49].

Существуют и другие классификации. Большинство из упомянутых подходов мы можем найти у отечественных исследователей. Так, вплоть до середины 60-х годов доминирующее положение в отечественном культуроведении занимала аксиологическая концепция культуры, представляющая ее как совокупность материальных и духовных ценностей. Именно такая трактовка нашла отражение во втором издании Большой советской энциклопедии, в Философской энциклопедии и других довольно многочисленных публикациях. К сторонникам этой концепции могут быть отнесены Г.Г. Козлов, А.А. Зворыкин, Г.П. Францев. Этот подход позволяет выявить общую социальную направленность культуры - содействовать общественному прогрессу, ибо ценностью является то, что имеет положительную социальную значимость: «Во всех явлениях культуры мы всегда найдем воплощение какой-нибудь признанной человеком ценности, ради которой эти явления или созданы, или, если они уже существовали раньше, взлелеяны человеком» [87].

Из сущности аксиологического подхода вытекает и его ограниченность. Вопросы о различии между ценностями и не-ценностями представителями одной культуры, одного поколения и даже одной социальной группы могут 
решаться неоднозначно. Более того, ряд исследователей считает, что «во всякой культуре есть не только ценности и идеалы, но также и антиценности, и антиидеалы (т.е. то, что противостоит ценностям и идеалам, является их отрицанием), а, кроме того, еще и такие культурные феномены, которые не имеют ценностного смысла и не оцениваются в этом плане». По мнению Т.И. Ойзермана, «культурный вандализм существует в рамках самой культуры как проявление ее разложения и самоотрицания».

Из подобной идеи исходили и классики русской философии. Так, П.А. Флоренский подчеркивал: «...в пределах самой культуры нет пределов для выбора критериев различения одного от другого: нельзя, оставаясь верным культуре, одобрять одно и не одобрять другого, принимать одно и отвергать другое...». На весьма важную сторону ограниченности ценностного подхода обращают внимание, в частности, исследователи политической культуры, подчеркивая, что «было бы неправомерно рассматривать политическую культуру как систему только широко разделяемых в обществе ценностей, убеждений и символов, ограничивать ее лишь «позитивными» установками в отношении существующей политической системы, как это делает ряд политологов. Концентрирование внимания исключительно на разделяемых всеми убеждениях, установках и ценностях чревато игнорированием политических убеждений, установок и ценностей, присущих тем или иным социальным группам, выступающим за изменение существующего положения вещей. Зачастую сам факт, что они не разделяются большинством членов общества, может служить важным показателем сущности и тенденций развития той или иной политической культуры и политической системы в целом» [80].

Тем не менее, следует подчеркнуть, что в последние годы вновь наблюдается активный интерес к аксиологическому пониманию культуры. Подтверждение тому - культурологические позиции Г.П. Выжлецова, В.Н. Сагатовского, В.М. Доброштана и др. 
Так, В.Н. Сагатовский пишет: «Культура есть процесс и результат реализации базовых ценностей субъекта (общества, группы, личности). Ценности есть внутреннее основание выбора целей и средств деятельности, ранжирования потребностей и возможностей субъекта, остающееся инвариантным для культуры определенного типа».

Обстоятельно обоснована концепция культуры как творческой деятельности в работах А.И. Арнольдова, Э.А. Баллера, Н.С. Злобина, В.И. Межуева, Н.З. Чавчавадзе. Здесь выделяется специфика становления новых элементов культуры в процессе духовного производства. Однако и в этом случае одни и те же социальные объекты могут то рассматриваться как элементы культуры, то исключаться из нее. Так, лишь первый образец конкретной технической системы должен при таком подходе рассматриваться как продукт научно-технического творчества и выступать элементом культуры. Остальные экземпляры той же системы в условиях массового производства есть результат репродуктивной, а не творческой деятельности и должны быть, с точки зрения данной концепции, исключены из структуры культуры [81].

В последнее время все более активно разрабатывается деятельностный подход к рассмотрению культуры, выявляющий ее взаимосвязь с человеческой деятельностью. Отметим, прежде всего, работы В.Е. Давидовича, Ю.А. Жданова, М.Т. Иовчука, М.С. Кагана, Э.С. Маркаряна, В.Г. Табачковского, В.В. Трушкова, А.И. Яценко. Опорными категориями для этого подхода выступают понятия «деятельность», «активность», «деятельный субъект». Реализующееся в деятельности единство субъективного и объективного позволяет понимать культуру как «систему внебиологически выработанных механизмов, благодаря которым стимулируется, программируется и реализуется активность людей в обществе» (Э.С. Маркарян). Другими словами, культура выступает как «способ деятельности» (В.Е. Давидович, Ю.А. Жданов), «технологический контекст деятельности» (3.И. Файнбург), придающей человеческой активности внутреннюю целостность и особого рода направленность, и выступает как 
способ регуляции, сохранения, воспроизведения и развития всей общественной жизни.

Многими учеными сегодня формулируются определения культуры, опирающиеся на относительно новые понятия естественных наук. В.С. Степин определяет культуру как «геном социальной жизни»: «Чтобы возник новый тип общества, должна возникнуть новая культурная матрица. Подобно тому, как геном определяет, каким будет организм, так тип культуры определяет, как будет воспроизводиться деятельность человека». Общим для этих концепций является стремление найти некоторую «субстанцию» культуры, ее объективного носителя.

Однако возможен и иной путь выявления сущности культуры — через ее наиболее общую социальную функцию, через ведущие социальные характеристики. Такая традиция складывается еще в классической западной философии, и ее общий смысл формулируется следующим положением: «культура есть развитие человека как разумного существа». При таком подходе создаваемое людьми предметное богатство общества есть лишь внешняя форма культуры. Её действительным содержанием оказывается развитие самого человека как общественного существа, т.е. развитие всей совокупности образующих ее отношений, сил, способностей и потребностей. П.С. Гуревич определяет культуру как «развертывание человеческих сущностных сил». В.Ж. Келле и М.Я. Ковальзон дали особенно острую формулировку этого подхода, заявляя, что «культура выступает как характеристика человека и только человека, как мера и синтетическая характеристика его духовного, нравственного, профессионального развития» [76].

Понимание культуры как сущностного выражения специфически человеческого бытия характерно для многих современных западных философов и культурологов. В 1983 г. на XVIII Всемирном философском конгрессе в Монреале (Канада), который был специально посвящен проблемам культуры, подобную точку зрения развивали Э. Левина, В. Матье, Н. Лобкович и др. 
Монреальский форум обозначил и закрепил современную проблематику философии культуры. В ходе обсуждения наметилась определенная последовательность проблем, которые в совокупности отражали содержание культурфилософии (термин введен немецким романтиком А. Мюллером). Что такое культура? Почему культура, будучи уникальным и относительно целостным феноменом, существует сегодня в столь значительном многообразии? Как должен вести себя человек перед фактом множественности и дифференциации культур? Что значит быть в культуре? Нетрудно видеть, что эти вопросы - уточнение понимания культуры как меры развития человека.

Рассмотрение культуры как меры развития самого человека позволяет определить сущностные характеристики частных областей или конкретных направлений культуры, а также обнаружить действительное единство иных концепций культуры, связанных с различными «субстанциями», или различных измерений культуры: - аксиологическое измерение показывает, какое значение для развития человека как родового существа имеет та или иная материальная (духовная) ценность; отметим, что нынешний интерес философов к аксиологической концепции культуры связан с позицией русских философовклассиков, большинство из которых высшей ценностью считало человеческую личность: «Мы должны, - отмечал Н.А. Бердяев, - бороться за новое общество, которое признает высшей ценностью человека, а не государство, общество, нацию»; - творческое измерение культуры раскрывает процесс становления новых сущностных сил человека; - деятельностный подход обращается к процессу формирования социальных качеств личности, к системе средств, способов, целей и результатов такого формирования. И самое важное: такой подход выявляет общую родовую черту культуры во всех ее направлениях - процесс общественного становления человеческой личности, ее развития именно как общественного, а не биологического существа. Культура при этом выступает как важнейший фактор социализации. Важно отметить, что речь идет о социализации не просто отдельной личности, но и 
конкретно-определенной социализации общественный групп и социальных общностей, в том числе и профессиональных [7, 59].

Таким образом, культура как всеохватывающее социальное явление заключается в самосозидании человеческой личности, в единстве всех ее социальных функций и общественных отношений, в реализацию которых эта личность оказывается включенной. Она характеризует степень развития и «качество» исполнения личностью всех ее социальных ролей. Однако каждая социальная роль, конкретная общественная функция личности в процессе ее деятельности предъявляет к личности совершенно определенные требования, нуждается во вполне определенном «наборе» качеств личности как основе эффективного выполнения социальных функций. Что касается социальной группы, то применительно к ней культура в рассматриваемом аспекте также выступает характеристикой качества социальных ролей, но взятых в совокупности, детерминируемой преобладающим для данной группы или социальной общности типом социальной деятельности. При этом подходе видовая - отличительная - сторона сущности культуры заключается в развитии человека как субъекта такого вида деятельности вместе со всей совокупностью его качеств.

Подобным образом может быть определена сущность и любой другой сферы культуры, например, политической, с учетом специфики той сферы социума, в которой работник действует как носитель определенных функций. Обобщая все многообразие подходов к определению культуры, можно выделить следующие ее существенные и необходимые признаки. Социальность. Культура всегда социальна и общественно значима. Природа сама по себе не создает и не содержит ценностей культуры. Поэтому нельзя, к примеру, сказать: «культурное дерево», «культурная река», «культурная погода» и т.п. Культурное имеет место и смысл только в применении к человеку и обществу, а также ко всему, что создано обществом. И в человеке культура касается лишь его социальной природы, но не биологических 
компонентов. Духовность. Культура духовна не в противоположность всему материальному, а в смысле одухотворенности еe высокими порывами человеческого сознания, духа.

Согласно общему правилу, чем больше духовности, тем выше культура. При этом под духовностью понимаются высокие и прекрасные порывы человеческой души. Традиция рассматривать культуру, прежде всего, как позитивно-духовное заложена в русской религиозно-философской классике. Такую позицию, например, отстаивал Н.А. Бердяев, у которого культура выступает сугубо духовным, элитарным явлением, противостоящим цивилизации. Конечно, культурные ценности имеют духовно-творческую, даже сакральную природу. Вместе с тем, неправомерно лишать культурологического измерения существующие в обществе материальные ценности, а также различные виды человеческой деятельности, которые содержат в себе полезные затраты как умственного, так и физического труда, т.е. являются духовнопрактическими [8].

Основу культуры составляет активная трудовая, общественно-полезная деятельность, которая только и может производить культурные ценности. Социальная деятельность сама по себе производит не только культурные продукты, но и некультурные, бесполезные. Преступность, например, - это тоже вид деятельности, но антисоциальный, вредный для общества, а потому не имеющий отношения к культуре. И поскольку в деятельностном плане культура общественно полезна, постольку она всегда прогрессивна, способствует поступательному развитию человека и общества в целом.

Общественная деятельность активно способствует созданию, хранению, распространению, распределению, обмену и потреблению культурных ценностей. Она производит и воспроизводит также предмет высшей ценности - самого человека. Общественная ценность. Культура аксиологична, имеет ценностную природу. Средства, способы и результаты полезной человеческой деятельности выступают в качестве специфической системы общественных 
ценностей. Ценность культуры состоит уже в том, что в ней заложен общественный труд. Этот труд касается не только создания, но и хранения культурных ценностей. И чем больше культурные ценности выдержали испытания временем, тем они ценнее и дороже. Одновременно аксиологический аспект культуры состоит в том, что она сама выступает мерой качества человека, его деятельности и общественных отношений, т.е. выполняет аксиологическую функцию. Благотворность, нравственногуманистическая природа.

Культура гуманистична, нацелена на удовлетворение человеческих потребностей и интересов, соответствует природе самого человека. В культурных ценностях всегда заложено нравственно-гуманистическое начало, т.е. благо, добро. И потому культура не может быть безнравственной, антигуманной. Человеческое измерение культуры выступает ее неотъемлемым признаком, без которого культура попросту невозможна. Совершенство, творческая природа. Культура всегда символична, гармонична, а в идеале совершенна по форме и содержанию. Понятие гармонии и совершенства приложимо, не только к способам и результатам, но и к процессу человеческой деятельности. Можно также говорить об искусстве и эстетической привлекательности данного вида общественного труда. Применительно к каждому виду деятельности культура выступает своеобразным эталоном ее совершенства, мерой ее качества и эффективности [18].

Подобная роль культуры закрепляется в терминах «культурный образец», «культурный идеал». В центре культуры всегда находится человек во всем богатстве его жизненных проявлений:

- познавательных - с точки зрения постижения истины и достижения правды;

- творческих - в аспекте конструктивных дерзаний человеческого духа и проявлений «прекрасных порывов души» (А.С. Пушкин); 
- нравственных — с позиций доброты и благонамеренности поведения; экономических, трудовых - с точки зрения его участия в производстве и потреблении материальных благ;

- правовых - с позиций исполнения законов государства; - эстетических — в плане художественного творчества и приобщения к ценностям культуры и искусства; - профессиональных — в отношении качества выполнения своих функциональных обязанностей [22].

Указанные существенные признаки культуры определяют ее в комплексе, в органическом единстве. И если какому-либо из них общественный продукт не соответствует, значит, он не может быть признан культурной ценностью. Так, например, в середине 90-х годов прошлого века в одном из книжных магазинов г. Пятигорска массовым тиражом продавалась книга под названием «Русский мат», в которой по алфавиту были представлены все, так сказать, варианты этого вида «народного творчества». Как ответить на вопрос: является ли данная книга культурной ценностью? Ответить на этот вопрос можно, подвергнув данную книгу оценке на предмет соответствия существенным признакам культуры.

С одной стороны, вполне понятным является факт, что на подготовку и издание книги был затрачен человеческий труд. Но, с другой стороны, что и какое явление стоит за данной книгой? Является ли русский мат культурной ценностью? Обладает ли он общественной полезностью? Можно ли без него обойтись в жизни? Возвышает ли он человека? Что в нем можно отметить с точки зрения духовности, творчества, совершенства и красоты? Ответ может быть однозначным - ничего культурного в русском мате нет и быть не может. И потому данная книга не может быть признана культурной ценностью. Кстати, следует отметить, что как в дореволюционное время, так и в советский период истории нашей страны предпринимались отдельные попытки подобных изданий, но они в корне пресекались государством. И только в смутное, переходное время падения нравственных идеалов и ослабления роли 
государства, в том числе и в сфере духовной жизни общества, стало возможным издание названной книги. Более того, можно не удивляться таким вариантам литературного «творчества», когда по средствам массовой информации тиражируются такие телепередачи, как «Алчность», «Слабое звено», «За окном» и другие, а в телерекламе давят на психику словесные штампы типа «Не тормози», «Оттянись по-современному», «Откосить от армии», «Устаканить вопрос» и т.п. Приходится лишь сожалеть и терпеливо ждать, когда во многих наших городах, в том числе и в Москве, наконец-то появятся такие названия, как «Площадь Любви», «Проспект Надежды», «Улица Добра», улицы Дружбы, Красоты, Чести и другие, подобные им. Несомненно, тогда люди будут становиться еще добрее, дружнее, честнее, красивее, а, значит, и культурнее [4]. 


\section{2. Содержание и закономерности развития культуры}

Культура, как уже отмечалось, является сложным и многогранным общественным явлением. В отличие от многих социальных явлений и сфер общественной жизнедеятельности, она не рядоположена с ними, а наличествует в каждом из них как мера оценки качественного уровня их развития, зрелости, совершенства. Это культурологическое измерение всей системы общественных отношений может быть выражено в трех основных уровнях: высоком, сверхдостаточном; среднем, достаточном; и низком, недостаточном. Содержание и структуру культуры в зависимости от различных оснований можно представить следующим образом [21]:

a) По способу создания и удовлетворения потребностей человека и общества различают две основных группы культурных ценностей: ценности материальной культуры и ценности духовной культуры. Материальная культура содержит те ценности, которые являются чувственно-предметными, удовлетворяют материальные потребности человека и общества и создаются преимущественно физическим трудом. Таковы, например, промышленные товары, одежда, продовольствие, жилье и т.п. Духовная культура содержит ценности невещественного, духовного порядка, которые призваны удовлетворять духовные потребности человека и общества и создаются преимущественно умственным трудом. К ним можно отнести нормы морали, религию, произведения искусства, научные открытия и т.п. Нетрудно заметить, что ценности материальной культуры всегда одухотворены сознательной деятельностью человека, а ценности духовной культуры всегда существуют и нуждаются в соответствующей материализации. Материальная культура тем ценнее, чем она одухотвореннее, а духовная культура тем выше, чем более она материализована в обществе и доступна человеку. Поэтому в принципе все культурные ценности являются духовно-материальными, хотя различие между ними в указанном отношении всегда имеет место. 
б) По общественной широте проявления, масштабам распространения и социальным носителям в содержании культуры выделяются такие интегративные группы культурных ценностей, которые называются субкультурами. К ним относятся:

- Глобальная, планетарная, общечеловеческая субкультура, ценности которой являются всеобщими для мирового сообщества. Таковы, например, нравственно-гуманистические ценности, не знающие национальных границ (гуманизм, честь, достоинство, долг, справедливость, свобода и т.п.).

- Континентальная, региональная субкультура, ценности которой рождены и распространены на американском, африканском, европейском, азиатском и других континентах. Носителями таких субкультур являются представители стран соответствующих континентов.

- Общественная субкультура, ценности которой утвердились и господствуют в каждом обществе, государстве. Таковы культурные ценности, характерные для каждой страны мира, в том числе и России. Отсюда идет выделение американской, германской, итальянской, французской, китайской и т.п., в том числе и российской субкультур.

- Социально-групповая культура содержит ценности, господствующие и распространенные в масштабе социальных групп - родов, племен, народностей, наций, кланов, сословий, конфессий и т.п. Так, культура России многонациональна и разноконфессиональна, поскольку в ее составе живут представители многих национальностей и религиозных конфессий. Она содержит такие субкультуры, как народная, национальная, городская, деревенская, молодежная и т.п.

- Личностная, индивидуальная культура каждого человека, которая содержит в себе ценности общечеловеческой, региональной, общественной, социально-групповой субкультур, а также и личной, неповторимо индивидуальной культуры. 
в) По проявлению в различных сферах жизнедеятельности общества выделяют: экономическую, социальную, политическую и духовную культуру. Каждая из перечисленных видов культуры, в свою очередь, содержит более конкретные ее разновидности. Например, экономическая культура общества включает: культуру промышленного производства, культуру сельскохозяйственного производства, культуру предпринимательской деятельности, культуру управления экономикой, культуру торговли, обмена и распределения материальных благ. Политическая культура общества содержит культуру политического устройства и режима власти, правовую культуру, культуру политического участия, культуру политического лидерства, культуру правоохранительной деятельности и т.п. Социальная культура включает культуру межличностных, семейно-бытовых, социально-групповых, межнациональных и иных отношений. В содержание духовной культуры общества входят познавательная, нравственная, религиозная, научная, эстетическая и другие виды духовной деятельности.

г) По характеру и многообразию видов человеческой деятельности человека различают обыденную и профессиональную культуру, а в составе последней выделяют: культуру управления, правовую культуру, педагогическую культуру, медицинскую культуру, военную культуру и т.п. В данном аспекте каждый вид профессиональной деятельности подвержен культурологическому измерению. При этом профессиональная культура по своему содержанию включает три основных слоя: общая культура личности, которой овладевает человек по мере своего становления; специальная культура, которая преимущественно связана с профессией человека; и специфическая культура, содержащая элементы индивидуального, собственного опыта в жизни каждого человека.

д) С точки зрения оценки индивидуального культурного облика каждого человека выделяются такие элементы культуры личности, как культура мышления, культура поведения, культура общения, культура 
взаимоотношений, семейная культура, культура досуга и быта и т.п. Понятно, что применительно к каждой разновидности культурного облика человека здесь речь идет о качественной оценке уровня зрелости, богатства и глубины мышления, поведения, общения, взаимоотношений и деятельности.

е) В аспекте взаимодействия общества и религии принято также различать культуру светскую, общественную, мирскую и культуру религиозную, сакральную, конфессиональную. Данное различение культур в значительной мере зависит от взаимодействия двух тенденций общественной жизни: сакрализации, усиления роли религии в обществе, и секуляризации, ослабления религиозности и повышения роли светских начал в общественной жизни. Чем выше роль религии в данном обществе, тем четче и яснее в нем имеет место различение между светской и религиозной культурами.

ж) В содержании художественной культуры общества по признаку социальных основ ее происхождения, широты распространения и уровню доступности для населения различают элитарную культуру, массовую культуру и народную культуру. Последняя, подразумевающая народное художественное творчество, нередко включается авторами в массовую культуру30. Элитарная культура производится и потребляется высшим привилегированным слоем общества - элитой. В общем смысле элита — часть общества, наиболее способная к творческой духовной деятельности и одаренная высокими нравственными и эстетическими задатками. Элитарная культура призвана удовлетворять духовные запросы высших и наиболее развитых, просвещенных слоев общества. Это, например, опера в музыкальном творчестве, балет в танцевальном искусстве, театр и т.п.

Массовая культура выступает своеобразным антиподом элитарной культуры [63]. К ней относится совокупность таких культурных ценностей, которые каждодневно производятся в больших объемах для массового распространения и потребления. Это культура повседневной жизни людей, представленная самой широкой аудитории по различным каналам, включая и 
средства массовой информации, и коммуникации. Таковы эстрадное творчество, песни и танцы, цирковое искусство, реклама, шоу-бизнес и т.д. Сюда же чаще всего относят и народную культуру - народные промыслы, сказки, предания, сказания и т.п. Наконец, культура каждого народа и государства имеет свое онтологическое содержание, которое включает такие необходимые элементы, как экономический уклад и политический строй общества, язык, мораль, искусство, образование и просвещение, наука и техника, религия, господствующая идеология и общественная психология. Это важно подчеркнуть, чтобы не сводить содержание культуры лишь к искусству, ценностям эстетического творчества. В данном аспекте культура как бы наполняет своим ценностным содержанием общественную жизнь. Следует иметь в виду, что в содержании указанных элементов культуры имеют место такие проявления, которые не соответствуют ее существенным признакам, а потому не могут быть признаны как культурные.

Так, например, язык сам по себе выступает необходимым элементом культуры каждого народа, средством еe развития, распространения и потребления. Но в функционировании и использовании языка нередко допускаются такие формы, которые в культурном плане недопустимы (грубость, искажение смысла, матерщина и т.п.). В процессе развития культуры действуют и проявляются закономерности - необходимые, устойчивые, существенные и повторяющиеся связи, которые определяют характер ее содержания, основные тенденции ее развития и функционирования. Нередко они проявляются как устойчивые и существенные факторы, под влиянием которых постоянно развивается культура.

В общей совокупности закономерностей развития культуры можно выделить две их группы: группа общих закономерностей внешнего порядка и группа специфических закономерностей внутреннего порядка [67]. Рассмотрим более подробно закономерности каждой группы. Общие закономерности развития культуры являются проявлением и конкретизацией действия 
всеобщих философских, а также общесоциологических законов. Важнейшая среди закономерностей этой группы - устойчивая и существенная зависимость содержания культуры от характера и особенностей исторической эпохи. Подобно тому, как философия, по меткому замечанию Г. Гегеля, есть эпоха, схваченная в мысли, культура также есть эпоха, схваченная в символах и архетипах. Названная закономерность проявляется прежде всего в том, что каждому периоду мировой истории и историческому этапу ее развития соответствует определенный исторический тип культуры. И потому историческая типология культур применительно к европейской истории включает в себя культуру эпох Древности, Средневековья, Возрождения, Нового и новейшего времени.

Культура как бы наполняет своим содержанием историю, олицетворяет собой каждый исторический период. Это лицо каждой исторической эпохи культурно выражается в ее экономической и политической жизни, языке, морали, науке, искусстве, образовании и просвещении, религии. В каждом обществе и на всех исторических этапах характер и уровень развития культуры существенно зависит от состояния экономической, социальной, политической и духовной жизни общества. Эта общая закономерность развития культуры может быть конкретизирована и рассмотрена применительно к каждой сфере жизнедеятельности общества как устойчивому и существенному фактору ее развития. Зависимость развития культуры от уровня экономической жизни общества является прямой: чем выше уровень развития экономики, тем более благоприятные условия она создает для развития культуры. Уже сама по себе развитая и эффективная экономика свидетельствует о высоком уровне экономической культуры данного общества, т.е. культуры промышленного и сельскохозяйственного производства, культуры предпринимательства и управления экономикой, а также торговли и других элементов экономической жизни общества [64]. 
Развитая экономика позволяет выделять больше средств на развитие культуры и соответственно получать высокую культурную отдачу на производстве в виде квалифицированных работников и т.П. В то же время нельзя не учитывать, что зависимость развития культуры от экономики не является прямолинейной, поскольку здесь одновременно сказывается влияние конкретной политики, состояния социальной сферы и характера духовной жизни общества. Развитие культуры устойчиво зависит и от характера политической жизни общества. Эта зависимость также не является прямолинейной. Известно, что демократическая политика создает более благоприятные условия для развития культуры. Яркий тому пример демократические Афины и военизированная Спарта в Древней Греции. Каждое государство вырабатывает и реализует культурную политику, которая может быть эффективной или неэффективной. В то же время воздействие политики на развитие культуры также зависит от уровня развития экономики, социальной сферы и духовной жизни данного общества.

Социальная сфера общественной жизни также оказывает существенное влияние на развитие культуры. Такие состояния общества, как социальная напряженность, социальная стабильность, социальное согласие и т.п. оказывают соответствующее влияние на культурный процесс. На характер культуры оказывает свое воздействие и социальная структура общества. Так, например, современная культура России по своему характеру и содержанию является многонациональной, разно региональной и светской. В целом более развитая социальная сфера жизни общества создает благоприятные условия для развития культурного процесса, но и здесь также одновременно сказывается влияние уровня экономической жизни, конкретной политики государства и традиций духовной жизни общества [24].

Более непосредственное и прямое влияние на развитие культуры оказывает духовная жизнь общества - национально-исторические традиции, образование и просвещение, идеология и общественная психология, наука и 
техника, мораль и искусство, язык и религия. Именно эти элементы духовной жизни определяют основное содержание культуры каждого государства, в том числе и России. И нередко богатые традиции, и высокие ценности духовной жизни в значительной мере покрывают издержки экономики, политики и социальной сферы. Так, например, невероятный взлет российской культуры в XIX веке трудно объяснить экономическими, политическими и социальными причинами. Он был подготовлен и обусловлен преимущественно духовными предпосылками.

В развитии культуры имеет место устойчивая и закономерная тенденция исторической преемственности и взаимодействия между различными типами культур. Эта тенденция выступает проявлением действия всеобщих философских законов - закона взаимодействия противоположностей и закона отрицания отрицания. В культурном процессе исключительно важна роль исторических достижений и традиций прошлого, сохранения и поступательного развития их в настоящем времени. И наоборот, прерывность исторического процесса, социальные революции, войны и т.п. негативно сказываются на развитии культуры. Культура по своему содержанию преимущественно ретроспективна. В ней наличествуют в основном ценности прошлого, которые выдержали испытание временем. И чем древнее культурная ценность, тем она ценнее. В то же время культурным ценностям настоящего времени еще предстоит выдержать это испытание, и далеко не каждая из них будет ревностно оберегаться обществом [2].

Одновременно культура каждого народа развивается во взаимодействии с другими, соседствующими культурами. Так, например, культура России исторически и постоянно развивается в диалоге с западной и восточной культурами. Культура подчиняется также действию закономерной тенденции расширения качественного многообразия по мере исторического развития. Здесь находит свое проявление философский закон взаимоперехода количественных и качественных изменений. В развитии культуры наблюдаются как постепенные, количественные изменения, так и крупные, качественно 
новые достижения, открытия, направления. Так, например, во второй половине XIX века в России вместе с традиционными направлениями художественного творчества (классицизм, реализм, романтизм) возникло и сложилось модернистское направление (футуризм, сюрреализм, имажинизм, акмеизм и др.).

Тенденция расширения качественного многообразия в развитии культуры всегда будет иметь место по мере усложнения и существенных изменений общественной жизни. Наконец, одной из общих закономерностей развития культуры является ее относительная самостоятельность и активное воздействие на общество. Конечно, культура рождается, формируется и развивается обществом. Она как бы неотделима от системы общественных отношений. И в то же время культура всегда автономна как особая и специфическая сфера высших проявлений человеческого духа. Особенно это касается культуры в ее наиболее узком понимании, т.е. художественной культуры. Возникнув и сформировавшись, культура оказывает активное благотворное воздействие на развитие всех сфер общественной жизни. Это воздействие выражается в ее социальных функциях [16].

Культура — это многофункциональная система. Коротко охарактеризуем основные функции культуры. Главной, родовой функцией культуры является человеко-творческая или гуманистическая. Все остальные так или иначе связаны с ней и даже вытекают из нее. В целом культура выполняет функцию социализации человека, превращая его из объекта воздействия социальной среды в активного субъекта общественной деятельности. Ради этого культура существует и развивается обществом. О высокой роли культуры в развитии общества и человека замечательно написал наш выдающийся писатель В.С. Пикуль в романе «Псы господни»: «Мне кажется, никогда не устареет блистательный вольтеровский афоризм о том, что «пышные бедра тициановской Венеры нанесли папе римскому вреда гораздо больше, чем все тезисы Лютера»..., ибо человек прежде всего остается человеком, и никто не 
смеет отнимать у него человеческое - дьявольскую красоту божественного тела» [1].

Родовая функция культуры конкретизируется в ее видовых функциях. Важнейшая из них - функция трансляции (передачи) социального опыта. Ее нередко называют функцией исторической преемственности или информационной. Культура, представляющая собой сложную знаковую систему, выступает единственным механизмом передачи социального опыта от поколения к поколению, от эпохи к эпохе, от одной страны к другой. Познавательная (гносеологическая) функция. Она тесно связана с первой. Культура, концентрирующая в себе лучший социальный опыт множества поколений людей, имманентно приобретает способность накапливать богатейшие знания о мире и тем самым создавать благоприятные возможности для его познания и освоения. Регулятивная (нормативная) функция культуры связана, прежде всего, с определением (регулированием) различных сторон, видов общественной и личной деятельности людей. В сфере труда, быта, межличностных отношений культура так или иначе влияет на поведение людей и регулирует их поступки, действия, в том числе и выбор тех или иных материальных или духовных ценностей. Семиотическая или знаковая функция — важнейшая в системе культуры. Представляя собой определенную знаковую систему, культура предполагает знание ее, владение ею. Без изучения соответствующих знаковых систем овладеть достижениями культуры невозможно. Знаковым средством общения людей выступает язык. Он же есть и культурная ценность, и важнейшее средство овладения национальной культурой [19].

Ценностная, или аксиологическая функция отражает важнейшее качественное состояние культуры. Культура как система ценностей формирует у человека вполне определенные ценностные потребности и ориентации. По их уровню и качеству люди чаще всего судят о степени культурности того или иного человека. Нравственное или интеллектуальное содержание, как правило, выступает критериям соответствующей оценки уровня культуры человека. 
Процесс функционирования культуры включает в себя такие элементы, как создание, накопление и хранение, распространение и потребление культурных ценностей. И чем совершеннее, богаче и выше культурные ценности, тем более они достойны сохранения и передачи новым поколениям людей. Вот почему до нас дошли из древних времен культурные достижения Древней Греции и Рима, египетские пирамиды, Вавилонская башня, Великая китайская стена, Софийский собор, Московский Кремль, собор Василия Блаженного и многие другие величайшие культурные ценности.

Вторую группу закономерностей развития культуры составляют существенные и необходимые связи и отношения внутреннего, специфического порядка. Они являются наиболее характерными именно для развития культуры как относительно самостоятельного и специфического общественного явления. К внутренним закономерностям развития культуры можно, прежде всего, отнести следующие. Взаимодействие содержания и формы в развитии культуры. Эта закономерность выражается в том, правдивость и глубина содержания каждой культурной ценности гармонически сочетается с совершенством ее формы. Вообще, взаимосвязь формы и содержания является диалектической закономерностью, обоснованной в рамках философии.

Согласно этой закономерности, содержание всегда определяет форму, а форма выражает характер содержания и активно воздействует на него. Однако в развитии культуры эта общая закономерность проявляется специфически. Главное в культуре - достижение гармонического соотношения содержания и формы. Если этой гармонии нет, то нет и культурной ценности. Поэтому ценности культуры обладают культовой символикой и способностью привлекать к себе внимание человека. Более того, они становятся предметом обожания, поклонения, подражания, а потому способствуют формированию и возвышению человека. Развитие культуры осуществляется под влиянием закономерного взаимодействия в ее содержании элементов общечеловеческой, региональной, общественной и социально-групповой культуры. Так, например, 
культура России, с одной стороны, развивается под воздействием соседствующих с ней западной и восточной культур, а с другой, - под влиянием взаимодействия в ее содержании различных элементов региональной, национальной, конфессиональной и социально-групповой субкультур [11].

В результате такого взаимодействия она получает качественное многообразие и такие специфические черты, как евразийство, единство западничества и славянофильства, духовная созерцательность, общинность, коллективизм и соборность, противоречивость и прерывность развития. Одной из внутренних закономерностей развития культуры является взаимодействие в ее содержании нравственно-гуманистических и художественно-эстетических элементов. Речь идет о том, что культурные ценности всегда содержат в себе положительное нравственное начало и высокую эстетическую привлекательность, красоту. Эти два компонента в культуре составляют органическое единство, взаимно обусловливая и дополняя друг друга. Отсутствие одного из них дезавуирует присутствие другого.

Так, произведение культуры не может быть признано высокохудожественным, если в нем отсутствует положительная нравственная идея. И наоборот, высокие нравственные порывы героев трудовых будней или военного лихолетья малопривлекательны при отсутствии элементарного умения людей хорошо трудиться и грамотно воевать. Наконец, специфической закономерностью развития культуры выступает взаимодействие в еe содержании элитарного и массового компонентов. Чем более развито общество во всех аспектах его жизнедеятельности и соответственно развита его культура, тем глубже и шире взаимопроникновение в ней элитарного и массового искусства. Более того, в развитом обществе элитарная культура расширяет свою социальную базу и все более становится массовой, а ценности и разновидности массовой культуры становятся все более привлекательными, художественно утонченными и интеллектуально возвышенными. 
Взаимодействие элитарного и массового в культуре общества и каждого человека должно быть гармоничным, без перекосов и крайностей.

Культурные потребности и вкусы человека многообразны, а потому он нуждается как в общедоступных и развлекательных ценностях массовой культуры, так и в приобщении к высокой эстетической нагрузке ценностей элитарной культуры. Что касается общества в целом, то в нем не должно иметь место явное преобладание массовой или элитарной культуры, свидетельствующее о несовершенстве всей системы общественных отношений. В культурном процессе действуют не только закономерности, но и многие другие факторы - исторические традиции, природный ландшафт и климат, географическое положение и геополитические предпосылки, территориальные и демографические условия, этно-национальные и конфессиональные факторы, социальные потрясения и природные катаклизмы. И потому культура, как чаще всего выражаются социологи, социодинамична [26].

Социодинамика культуры выражается не только в ее поступательном, восходящем, прогрессивном историческом развитии, но и в элементах повторяемости и цикличности, деградации и регресса, культурного застоя и кризиса, а также культурных взрывов и катастроф. Так, например, можно назвать культурным взрывом бурное развитие православной культуры на Руси после принятия христианства.

С другой стороны, после революционных событий 1917 г. в России целые культурные пространства оказались в состоянии кризиса или катастрофы. В частности, культурная катастрофа постигла такие культуры, как купеческая, дворянская и мещанская. В состоянии кризиса оказались православная культура и культуры других конфессий, а также отдельные элементы элитарной культуры [32]. 


\section{3. Культура и цивилизация}

Российская цивилизация в диалоге западной и восточной культур Понятие цивилизации. В предыдущей главе понятие цивилизации рассматривалось нами как этап развития человеческого общества, сопоставляемый с понятием «общественно-экономическая формация». Сопоставление цивилизации с понятием «культура» заставляет рассмотреть ее как качественную характеристику общества, как ее специфическую сторону. Исследователи выделяют, по меньшей мере, шесть наиболее распространенных смыслов понятия «цивилизация» [82]:

- оно выступает синонимом понятия «культура» (цивилизация Древнего Рима и культура Древнего Рима);

- оно рассматривается как обозначение «вещного», предметного тела общества в противоположность его духовному началу: «цивилизация преобразованный человеком мир внеположных ему материальных объектов», — подчеркивает А.Г. Спиркин;

- цивилизация обозначает этап старения и упадка культуры (О. Шпенглер);

- оно употребляется для выявления конкретного локализованного общества («цивилизация Вавилона»);

- оно используется в археологии для обозначения технологического уровня развития общества (шелльская цивилизация, цивилизация каменного века);

- наконец, оно выступает синонимом состояния общества, наступающего после первобытнообщинного строя, после «варварства». «Цивилизация — такая связь в развитии человечества, когда социальные связи начинают доминировать над природными, и когда общество начинает функционировать на своей собственной основе», - отмечает И.А. Гобозов. 
Таким образом, подходов к пониманию цивилизации достаточно много. В современной социально-философской литературе постепенно складывается взгляд на цивилизацию как на качественную специфику группы стран и народов на определенном этапе развития. И если для общественноэкономической формации преимущественным критерием является способ материального производства, то специфика цивилизации, не отказываясь от учета материальных отношений общества, более тяготеет к выделению духовных аспектов и критериев [73]. В числе таких аспектов чаще всего выделяют:

- специфическую общественно-производственную техноологию;

- общественно значимые духовные ценности, своеобразную философию общества;

- обобщенный образ мира, сложившийся в общественном сознании (нередко он соответствует определенной религии);

- специфический образ жизни народа, базирующийся на сложившейся морали, духе народа, его самосознании.

Таким образом, понятие цивилизация в известном смысле оказывается более широким, чем понятие формации. Многие современные исследователи подчеркивают, что при цивилизационном подходе в центре рассмотрения оказывается человек, поэтому такой подход позволяет объяснить явления и процессы, которые не укладываются в схему формационного анализа. Понятие цивилизации появилось в XVIII веке, французские философы-просветители называли цивилизацией общество, основанное на началах разума и справедливости.

Цивилизация включает в себя преобразованную человеком, окультуренную, историческую природу и средства этого преобразования, человека, усвоившего культуру и способного жить и действовать в окультуренной среде. Цивилизация, следовательно, выступает как социокультурное образование. Понятие «культура» характеризует человека, 
определяет меру его развития, поэтому можно сказать: культура - способ бытия человека. Что касается понятия «цивилизация», то оно характеризует социальное бытие самой культуры. В философской мысли существуют разные подходы к осмыслению соотношения культуры и цивилизации [75].

В некоторых концепциях критика культуры, начатая Руссо, доводится до полного еe отрицания, выдвигаются идеи «природной антикультурности» человека, остающегося при этом «цивилизованным». Доведение до крайнего выражения того подхода, когда в цивилизациях видят лишь различия и отрицают преемственность, повторяемость отдельных черт исторического процесса, - фактически приводит и к отрицанию всемирной истории, которая распадается на отдельные истории отдельных цивилизаций (Н.Я. Данилевский, А. Тойнби, П.А. Сорокин). Нетрудно видеть, что такого рода выводы противоречат современным тенденциям развития человечества, когда резко усиливается взаимозависимость и взаимовлияние различных стран и народов. Актуальнейшим вопросом для российского общества является решение вопроса о соотношении западной и восточной культур и цивилизаций, о месте России в диалоге этих культур.

C точки зрения цивилизационного подхода Запад и Восток рассматриваются не как географические, а как геосоциокультурные понятия. Специфика западной цивилизации. Современные исследователи под термином «Запад» понимают тот особый тип цивилизационного и культурного развития, который сформировался в Европе примерно в XV-XVII вв. Цивилизация этого типа чаще всего именуется техногенной. Характерными чертами этой цивилизации являются динамичное развитие техники и технологий, систематическое применение в производстве научных знаний.

В результате научные и научно-технические революции коренным образом изменяют место человека в производстве и его отношение к природе. По мере развития техники ускоренно изменяется созданная человеком «вторая природа», что, в свою очередь, вызывает существенную трансформацию 
социальных связей. Иногда в течение одного-двух поколений происходят изменение образа жизни и формирование нового типа личности. Западная культура в ее современном виде опирается на предпосылки, формировавшиеся в период античности и средневековья.

Наиболее существенные факторы этого исторического периода, которые определили лицо западной цивилизации, могут быть сведены к следующим [74]:

- опыт демократии античного полиса;

- становление в рамках полисной культуры различных философских систем и зарождение науки в ее нынешнем понимании;

- христианская традиция с еe представлениями о человеческой индивидуальности, концепцией морали, пониманием человека и его разума, как созданных «по образу и подобию Божьему».

В эпоху Просвещения сформировались те предпосылки и мировоззренческие установки, которые определили последующее развитие техногенной цивилизации. В числе этих установок следует, прежде всего, подчеркнуть особую ценность прогресса науки и техники, убеждение в возможности разумного рационального обустройства общества. Обычно в социально-историческом плане западная цивилизация отождествляется с периодом становления и развития капиталистических экономических отношений и буржуазной формы государственной демократии, со становлением гражданского общества. В технико-технологическом аспекте западная цивилизация отождествляется с индустриальным и постиндустриальным обществом [89, 90].

Становление этой цивилизации происходило в тесном переплетении материальных и духовных факторов. Немецкий исследователь М. Вебер в знаменитой книге «Протестантская этика и дух капитализма» показал роль протестантской Реформации и религиозного духа кальвинизма в становлении основных духовных ценностей капиталистического общества. В числе этих 
ценностей: динамизм, ориентация на новизну; утверждение достоинства и уважения к человеческой личности; индивидуализм, установка на автономность личности; рациональность; идеалы свободы, равенства, терпимости; уважение к частной собственности. Особенности традиционного общества. Известно, что мировая история началась с Востока, именно он - очаг цивилизации. Здесь возникли и приобрели устойчивые формы древнейшие социальные и политические институты. Недаром древние римляне с уважением говорили: «Сеет - с Востока» [51].

В геополитическом аспекте этот тип цивилизации связывают с культурами Древней Индии и Китая, Вавилона, Древнего Египта, государственными образованиями мусульманского мира. Каждая из этих культур отличалась самобытностью. Так, в Древнем Китае сын крестьянина мог за счет образования попасть в высшие слои общества, а в Индии существовали замкнутые касты; японские самураи с презрением относились к низшим слоям общества, а рыцари Китая считали долгом вступаться за обиженных и отстаивать справедливость. Однако между обществами традиционной культуры гораздо больше сходства, чем различий. Отметим наиболее существенные их общие черты. Традиционные общества ориентированы, прежде всего, на воспроизводство устоявшихся социальных структур, на стабилизацию сложившегося образа жизни.

В качестве высшей ценности рассматриваются традиционные алгоритмы поведения, аккумулирующие опыт предков (отсюда - «традиционное» общество). Виды и цели общественной деятельности меняются очень медленно, в течение столетий они воспроизводятся как устойчивые стереотипы. Именно огромная роль традиции в жизни рассматриваемой цивилизации определила длительность ее существования. Если современная западная цивилизация считается существующей ок. 300-400 лет, то исследователи Востока определяют срок жизни традиционной цивилизации на протяжении огромного промежутка в 3 тысячи лет - с сер. II тыс. до н. э. по XVII-XVIII вв. н.э. с 
сохранением существенных характеристик этой цивилизации по настоящее время. Было бы ошибочно считать, что Восток стоял на месте. Он эволюционировал, но динамика его развития отличалась от западной. Отвергались те новации, которые могли угрожать стабильности Востока [64].

В Европе двигателем прогресса был гражданин-собственник. На Востоке отбирались лишь те новшества, которые соответствовали нормам корпоративной этики и интересам государства, и были направлены на укрепление эффективности власти или стабильности государства. Восток очень гибок, он оказывается способным вобрать в себя и переработать многие чуждые элементы. Если для Рима нашествие варварских племен означало конец цивилизации, то для Китая нашествия «варваров» (кочевых племен на границах с Китаем, которые, как и гунны, захватившие Рим, находились на стадии разложения первобытнообщинного строя) даже не прервало существования китайского государства, ибо коренное население ассимилировало пришельцев и привило им ценности своей цивилизации. Александр Македонский покорил весь Ближний Восток, основал громадную империю. После него осталась система эллинских государств. Но Восток переварил и Селевкидов, и Птолемеев, и привнесенную в завоеванные страны великолепную культуру древних греков, которая, казалось бы, навсегда там утвердилась. Однажды все вернулось на круги своя — к своему извечному порядку.

Особенно характерна способность к ассимиляции для Японии, которая во многом шла по пути заимствований и преобразований на свой лад из философии, традиций, наук, боевых искусств других народов. В духовной сфере традиционного общества господствуют религиозно-мифологические представления и канонизированные стили мышления. Научной рациональности в этих обществах противопоставляется нравственно-волевая установка на созерцательность, безмятежность, интуитивно-мистическое слияние с бытием, с миром. В отличие от Запада, на Востоке существовало множество религий, и даже ислам, непримиримый к западному христианству, уживался с восточными 
верованиями. Человек Востока представлял существование всего живого как вечный круговорот в замкнутом цикле, что и порождало знаменитый восточный фатализм как веру в невозможность и ненужность изменения предначертанной Богом судьбы.

Для восточного мировоззрения не характерно разделение мира на мир природы и мир человека, на естественный и сверхъестественный, ему присущ синтетический подход «все-во-всем». Поэтому свобода и достоинство человеческой личности, ее автономия чужды духу восточной культуры, для которой характерна ориентация на коллективизм. Восточный человек не свободен, а обязан. Он обязан соблюдать традиции, ритуалы, системы подчинения (вышестоящий - нижестоящий, родители - дети, муж - жена), обязан вести определенный образ жизни. Общество Востока никогда не утрачивало связь с природой. Европейцы слабость перед силами природы компенсировали созданием технических устройств, противопоставляя тем самым себя природе и не ощущая себя ее частью. Целью людей Востока стало стремление жить в гармонии с природой, познав ее законы.

Излюбленная идея восточных философов состоит в том, что народы и государства должны развиваться естественным образом, во всем беря пример с природы, где в жизни растений и животных нет ничего лишнего, ничего случайного. Доскональное знание природы позволяло восточному человеку точно предсказывать ее воздействие на организм [65].

Эти особенности восточной цивилизации предопределяют и специфику социально-политического и государственного устройства. Дух демократии и гражданского общества чужд традиционной цивилизации, поэтому попытки привить нормы западной демократии на восточной почве дают весьма причудливые гибриды. В южных республиках Советского Союза даже структурная организация Коммунистической партии очень тесно коррелировала с традициями родоплеменной организации общества. Следует учитывать, что рассмотренные схемы - не что иное, как теоретические модели 
двух цивилизаций, в реальной действительности дело обстоит гораздо сложнее, и реальные общества выступают как результат взаимодействия и взаимозависимости всех ныне существующих культур и цивилизаций. Вместе с тем рассмотренная модель представляет собой достаточно надежную отправную точку для классификации современных обществ.

Цивилизация России. Попытка выделить своеобразие и историческую роль различных культур и цивилизаций для граждан России связана с необходимостью осмыслить отечественную историю, определить место России в мировой цивилизации, выявить значение западного и восточного культурного наследия для культуры в России, ответить на вопрос: возможен ли и необходим ли самобытный путь развития России? [66]. Эта проблема была поставлена еще в 30-х годах XIX в. русским философом П.Я. Чаадаевым, который по поводу особого пути России утверждал, что надо доказать, что человечество, помимо двух своих сторон, определяемых словами - Запад и Восток, обладает еще третьей стороной. Такое доказательство стремились представить идеологи славянофильства: И.В. Киреевский, А.С. Хомяков, К.С. Аксаков. Они связывали идею самобытности русского пути с приверженностью русского народа православию. С их точки зрения православие выступает источником специфических черт «русской души»: глубокой религиозности, повышенной эмоциональности, коллективистских ценностей, приверженности к самодержавию. Их оппонентами выступили «западники»: К.Д. Кавелин, А.И. Герцен, Н.Г. Чернышевский, Б.И. Чичерин и др. Они рассматривали Россию как во многом еще азиатскую страну, которой необходимо перенимать лучшие образцы западной культуры и образа жизни, по-западному цивилизовываться.

После Октябрьской революции этот вопрос активно обсуждался русской философской эмиграцией, прежде всего, в ряде крупных работ Н.А. Бердяева, В.В. Зеньковского, Г.П. Федотова, Г.В. Флоровского и др. В книге Н.А. Бердяева «Русская идея. Основные проблемы русской мысли ХІХ и начала 
ХХ века» говорилось о невозможности строго научного определения народной индивидуальности, в которой всегда есть нечто непостижимое. Для русской индивидуальности, по мнению Н.А. Бердяева, характерной является глубокая поляризованность и противоречивость: «Русский народ не есть чисто европейский и не чисто азиатский народ. Россия есть целая часть света, огромный Востоко-Запад, она соединяет два мира. И всегда в русской душе боролось два начала, восточное и западное» [52].

С точки зрения Бердяева, русский народ был народом откровений и вдохновений, а не упорядоченной рациональной культуры. В основании русской души лежат два противоположных начала: языческая дионистическая стихия и аскетически-монашеское православие, что и обусловило двойственность духовных качеств народа: гипертрофия государства и анархизм; склонность к насилию и склонность к доброте; индивидуализм, обостренное сознание личности и коллективизм; искание Бога и воинствующее безбожие; смирение и наглость; рабство и бунт.

Бердяев считал, что эти черты предопределили сложность и катаклизмы российской истории. Несколько по-иному тема о самобытных основах российской истории и культуры решается в работах представителей так называемого евразийского движения (П.А. Карсавина, Я.С. Трубецкого, П.П. Стучинского и т.д.). Евразийство возникло и существовало как общественно-политическое и идейное течение русской эмигрантской интеллигенции с начала 20-х до конца 30-х гг. ХХ в. Историко-культурная концепция евразийства рассматривает Россию как Евразию - особый географический и этнографический мир, занимающий срединное пространство Азии и Европы. Этот мир имеет самобытную культуру, «равно отличную от европейских и азиатских» [53].

Евразийцы подчеркивали преобладающие азиатские черты русской культуры, выделяя преемственность Руси с империей Чингиз-хана и заявляя, что «русская революция прорубила окно в Азию». Евразийцы считали, что после Октябрьской революции старая Россия со всей ее государственностью и 
укладом жизни потерпела крушение и канула в вечность. Новая эпоха открывается мировой войной и русской революцией.

Для этой эпохи характерно не только исчезновение прошлой России, но и разложение Европы, всеобъемлющий кризис Запада. А Запад, по мнению евразийцев, полностью исчерпал свой духовно-исторический потенциал. Будущее же в этой новой эпохе они отводили обновленной России, а вместе с ней и всему православному миру.

Таким образом, евразийцы в значительной мере наследуют традиции славянофилов. Темы, поднятые в дискуссиях западников и славянофилов, Н.А. Бердяевым и евразийцами, продолжают обсуждаться современной российской общественностью, прежде всего, философами. Для многих из них ясно, что развитие западной техногенной культуры и цивилизации привело человечество к глобальным проблемам и системному кризису. В связи с этим ставится вопрос: можем ли мы воспринимать западный опыт как некоторый идеал или сам этот опыт должен быть подвергнут критическому анализу? Возможно, человечеству для выживания необходимо встать на новый путь цивилизационного развития. А это может означать, что наступивший в России глубокий кризис всех сфер общественной жизни и есть необходимый момент, который может послужить толчком для создания этого нового типа цивилизационного развития [58].

В российской культуре существуют значительные основания для выработки такого пути развития, основными ценностями которого явилась бы ориентация не на безостановочный рост материального производства и потребительства, а на аскетическую умеренность, основанную на приоритете духовных ценностей. Холодному экономическому расчету должны противостоять теплота человеческих отношений и христианское самопожертвование, а западному индивидуализму — братская взаимопомощь и коллективизм. Технологический, экономический и правовой рационализм плохо уживаются с нравственной верой в добро. 
Частнопредпринимательская деятельность, жесткая конкуренция резко ограничивают сферу сострадания и милосердия, деформируют нравственные принципы братства и уважения к каждой личности. Более конкретные вопросы связаны с социальной спецификой сегодняшней ситуации в государствах бывшего СССР. Каковы пути и исторические судьбы той общности, которая раньше называлась Россией, соберется ли она вновь или процесс ее распада необратим? Подобного рода вопросы предстоит решить, как теоретически, так и практически не только нам, но и будущим поколениям народов некогда великих Российской империи и Советского Союза [12].

Таким образом:

1. Каждый человек должен знать и постигать культуру, поскольку именно через систему культурных ценностей происходит постоянное взаимодействие человека и человечества, и человек выступает не изолированной особью, а представителем общества. Вместе с тем он должен быть в системе культуры. Цивилизованный человек тоже знает культуру, однако она не стала содержанием его убеждений, характеристикой его стремлений и целей. У культурного человека ценности культуры входят в содержание основной мотивации его деятельности.

2. Человек выступает как цель культуры, ибо человекотворчество - ее главная характеристика. Поэтому нельзя рассматривать человека только как средство культуры, как ее орудие. Формирование необходимых качеств личности через культуру — это самый надежный и эффективный путь социализации личности, хотя и наиболее трудоемкий с точки зрения прилагаемых воспитательных усилий. Этот вывод наиболее важен для будущего социального работника: его клиент — это цель социальной работы, а не средство самоутверждения профессионала и его карьерного роста.

3. Поскольку культура характеризует качество исполнения личностью ее социальных ролей, степень ее свободы в конкретных системах социальных отношений, то могут быть выделены конкретные виды культуры, соответствующие конкретным видам человеческой деятельности. Нетрудно 
видеть, что все социальные роли, связывающие человека с системой культуры, требуют от него последовательной и настойчивой работы над собой, неустанного приобщения к культурным ценностям человечества. Правильно поступают те студенты, которые с наибольшей пользой для этого используют свои наиболее плодотворные студенческие годы и наиболее благоприятные условия - условия учебы в ВУЗе - для усвоения и постижения культурных ценностей.

\section{Вопросы для самоконтроля}

1. Что означает понятие культуры в этимологическом смысле?

2. Как развивалось понятие культуры в историческом плане?

3. Почему существует множество определений культуры?

4. Какие основные подходы возможны к определению культуры? 5. Раскройте существенные признаки культуры.

6. В чем состоит взаимосвязь материальной и духовной культуры?

7. В какие субкультуры объединяются различные группы культурных ценностей?

8. Как понимаются и различаются закономерности развития культуры?

9. Раскройте общие закономерности культурного процесса.

10. Какие внутренние закономерности характерны для развития культуры?

11. Какую роль выполняет культура в развитии общества и человека? 


\section{3. КУЛЬТУРА РОССИИ НА ПУТИ К ИНДУСТРИАЛЬНОМУ ОБЩЕСТВУ}

\section{1. Естественно-научные источники развития российской культуры}

В первой половине XIX века в области просвещения наметилась реорганизация школьного дела. Готовилась единая система народного образования. В 1802 г. появилось Министерство народного просвещения; были основаны новые университеты [17]: Дерптский, Виленский, Казанский, Харьковский, Киевский. Систематическим стало устройство средних учебных заведений - гимназий - для дворянских и чиновничьих детей. Для подготовки высших государственных чинов открываются лицеи; техническую подготовку дают Институт инженеров путей сообщения, Техническое училище, Училище гражданских инженеров. Число учащихся средних и низших учебных заведений возрастает с 120 тыс. до 450 тыс. человек.

Появляются сельские школы для крестьян, но процент грамотности в деревнях очень низок: 5-7\% среди государственных крестьян, $1 \%$ - среди помещичьих. Российская наука, получившая в новых университетах значительную опору, вышла на уровень мирового признания. Ректор Казанского университета Н.И. Лобачевский создал новую «неэвклидову» геометрию. В том же университете работали Н.Н. Зинин и А.М. Бутлеров, внесшие вклад в становление органической химии. В Дерптском университете работал знаменитый хирург Н.И. Пирогов, основоположник анатомоэкспериментального направления в хирургии, основатель всемирно известного атласа «Топографическая анатомия». Петербургские академики В.В. Петров и Б.С. Якоби значительно продвинули электротехнику: Петров открыл в 1802 г. электрическую дугу; Якоби изобрел и опробовал электродвигатель (1834-1838), создал гальванотехнику (1838), несколько типов телеграфных аппаратов. В 1839 г. была отрыта Пулковская обсерватория [69]. 
Для развития гуманитарных наук много сделал Н.М. Карамзин, чья «История Государства Российского» (1816-1829) была не только новым этапом в становлении исторической науки, но и вкладом в развитие русского литературного языка, пробудила интерес образованных кругов к прошлому России. Славянофилы активизируют собирание и изучение фольклора. В 1803-1806 гг. И.Ф. Крузенштерн и Ю.Ф. Лисянский совершили первое из 40 русских кругосветных путешествий, уточнили карту мира, описали жизнь народов Камчатки и Сахалина. В январе 1821 г. было сделано величайшее географическое открытие XIX в. - Ф.Ф. Беллинсгаузен и М.П. Лазарев открыли шестую часть света - Антарктиду. Первая половина XIX в. отмечена и преобразованиями в управлении государством — в 1802 г. Александр I издал манифест, согласно которому устаревшая и частично развалившаяся система петровских коллегий была заменена министерствами (вначале их было восемь). Во второй половине XIX века просвещение и наука развивались в условиях, создавшихся после отмены крепостного права. Сеть начальных учебных заведений состояла из [70]:

1) церковно-приходских школ (два или четыре класса образования давали знание основ грамоты, счета, письма и Закона Божия);

2) школ, открытых земствами, с более широкой программой и лучшей постановкой преподавания;

3) крестьянских школ грамоты. По уставу 1871 г. единственной формой среднего образования стала классическая гимназия, в которой более $40 \%$ учебного времени отводилось на изучение древних языков. На основании специального министерского циркуляра («о кухаркиных детях») был ограничен прием в гимназию детей малоимущих родителей. В то же время количество гимназий, как и количество учащихся, возросло с 1861 г. по 1895 г. в 2,5 раза. Росло число грамотных: к началу 60-х годов они составляли 7\% населения России, а к концу 90-х - 21\%.

В области высшего образования происходил быстрый рост технических учебных заведений (среди них Высшее техническое училище в Москве) при 64 
незначительном росте числа университетов (в Одессе и Томске). Если в 60-е годы университеты получали автономию, то в 80-е она была практически упразднена (отменена выборность ректоров, деканов, профессоров, усилился надзор за студентами). По инициативе общественности создавались воскресные школы для взрослых. В пореформенные годы открываются женские гимназии и высшие женские курсы, в том числе врачебные. В развитии науки первостепенное значение приобретают математика и естествознание [15].

Характерной чертой петербургской школы математиков во главе с П.Л. Чебышевым была тесная связь теории и практики. Математик Софья Ковалевская получила образование и научное признание за границей, став профессором Стокгольмского университета. Она была также писательницей. Создателем московской школы физиков стал А.Г. Столетов (работы по магнетизму и фотоэлектрическим явлениям). Химик А.М. Бутлеров создал теорию строения веществ, основные положения которой лежат в основе современной теории органических соединений. Д.И. Менделеев открыл периодический закон химических элементов. И.М. Сеченов - основоположник русской физиологической школы - в работе «Рефлексы головного мозга» дал физиологическое объяснение психическим явлениям и выражениям чувств. А.Ф. Можайский сконструировал первый в мире самолет. А.С. Попов изобрел радиотелеграф, П.Н. Яблочков и А.Н. Лодыгин - электрическую лампочку (переворот в технике освещения, передачи, сохранения и распределения энергии). Географические экспедиции П.П. Семенова-Тян-Шанского и Н.М. Пржевальского положили начало научному обследованию Средней и Центральной Азии. Н.Н. Миклухо-Маклай изучал быт, нравы, хозяйство и материальную культуру народностей Юго-Восточной Азии, Австралии и Океании [9].

Созданием обобщающих трудов по отечественной истории внесли свой вклад в науку С.М. Соловьев и В.О. Ключевский. Выдающимся религиозным философом был Владимир Сергеевич Соловьев (сын историка). Новым 
явлением в общественно-культурной жизни второй половины XVIII - начала XIX в. стало масонство, сложное религиозно-этическое движение, возникшее в Англии еще в начале XVIII в. В России это были главным образом «розенкрейцеры». Главная идея массонства в России - совершенствование личности через просвещение. Идеи русского просветительства отражали А.Я. Поленов, С.Е. Десницкий, Н.И. Новиков, Д.И. Фонвизин, И.А. Крылов и др. Вслед за ними выступил А.Н. Радищев. В первой половине XIX в. на общественной мысли сказывается влияние войны 1812 г. В 20-40-е гг. в России становятся популярными произведения Фихте, Шеллинга, Гегеля. Шеллинг, по мнению некоторых ученых, вообще значил для России больше, чем для Германии [72].

Неотъемлемая часть общественной жизни XIX в. - противоборство славянофилов и западников. При этом на стороне славянофилов выступали Алексей Степанович Хомяков, Иван Васильевич Киреевский, Константин Сергеевич Аксаков, Иван Сергеевич Аксаков, Юрий Федорович Самарин. Видными представителями западничества были П.Я. Чаадаев, Н.В. Станкевич, В.Г. Белинский, М.А. Бакунин, А. И. Герцен. Позднее на арену общественной мысли выходит идеология народничества и идеология социал-демократии.

Три-четыре десятилетия середины XIX в. в истории России стали переходным периодом к индустриальной цивилизации. Крепостничество связывало развитие производительных сил. С 1800 по 1860 гг. население страны увеличилось в 2,1 раза, а сбор хлеба вырос всего на 42\%. Выплавка чугуна увеличилась в 1,7 раза (в Англии за тот же период — в 24 раза). Прекратился вывоз железа и увеличился вывоз зерна в 5,4 раза. По объему производства промышленной продукции в 1864 г. Россия уступала Великобритании в 18 раз, Германии — в 9 раз, Франции — в 7,2 раза. Доля России в мировом промышленном производстве упала до $1,7 \%$. Хронологически индустриальная цивилизация в России охватывает период с 60-х годов XIX в. до начала XXI в. Это меньше, чем в промышленных странах 
Западной Европы. Причина состоит в том, что промышленная революция в России задержалась примерно на полстолетия по сравнению с Великобританией; переходный период к постиндустриальной цивилизации начался на 15-20 лет позднее, чем в странах, находившихся в авангарде исторического прогресса. В рамках этого цивилизованного исторического цикла можно выделить несколько крупных этапов (полувековых циклов) [78]:

1) 1861-1913 гг. (52 года) - период ускоренного распространения индустриальной цивилизации, промышленного переворота, утверждения капитализма и вступления его в империалистическую стадию, подъема науки, культуры и образования, первых признаков общенационального кризиса (поражение в русско-японской войне, революция 1905 г.).

2) 1914-1964гг. (50 лет) - период общенационального кризиса и попытки его решения в рамках социалистического варианта развития, не считаясь с жертвами, ценой крайнего напряжения сил. Но в этот период страна победила в Отечественной войне, была создана мощная военно-индустриальная держава.

3) 1965-2010 (45 лет) — завершающая фаза индустриальной цивилизации в России, попытки с помощью реформ трансформировать социалистическую экономику, крушение ее основ, очередной общенациональный кризис,

4) Охвативший экономику, социальную, государственно-политическую и духовную сферы, постепенный болезненный выход из кризиса, формирование предпосылок постиндустриальной цивилизации.

Давайте рассмотрим более детально узловые тенденции каждого из полувековых циклов современной истории России. Период промышленного переворота и утверждения капитализма, в свою очередь, разбивается на пять среднесрочных циклов, которые во многом совпадали с ритмом мировых экономических циклов, специфически отражаясь в экономике и социальнополитической сфере России [84].

1) 1861-1871 - выход из общенационального кризиса, проведение серии реформ, охвативших все стороны жизни общества. Общество преобразуется без 
крупных революционных потрясений. Проводятся земельная реформа, земская, судебная, образовательная, городская, военная. Начинается конструктивная реформаторская деятельность. Хотя эти реформы, особенно крестьянская, носили половинчатый, компромиссный характер, они дали свои результаты. Социального взрыва удалось избежать.

2) 1872-1882 — начало пореформенного подъема, ускоренной индустриализации, начало подъема уровня жизни, науки и образования. Добыча угля за десятилетие увеличилась в 3,5 раза, нефти - в 32,8 раза, выплавка стали - в 27 раз; медленнее росли выпуск продукции машиностроения - на 62\%, химической промышленности - 60\%, протяженность железных дорог - на $62 \%$.

3) 1883-1892 - промышленное производство и транспорт продолжали развиваться, хотя и более медленными, чем в предыдущее десятилетие темпами: добыча угля за десятилетие выросла на 84\%, нефти - в 5,9 раза, выплавка стали - в 2,1 раза, производство машиностроительной продукции всего на $6 \%$, химической — в 2,2 раза, длина железных дорог - на 33\%; обострялись социальные противоречия.

4) 1893-1903 - период ускоренного промышленного подъема, особенно в связи с массовым притоком иностранного капитала. По темпам экономического роста Россия обогнала развитые промышленные страны: в 90-е годы среднегодовые темпы прироста промышленного производства (по 50 губерниям Европейской России) составили 6,2\%, тогда как в Германии 5,1\%, Англии - 1,7\%. Однако сельское хозяйство, где средний надел уменьшился с 4,8 десятин в 1861 г. до 2,6 десятин в 1900 г., топталось на месте. Разразился аграрный кризис, который привел к неурожаям 1889, 1891 и 1892 гг., уменьшился вывоз хлеба, его доля в структуре экспорта снизилась с 49\% в 1890 г. до 43\% в 1900. В конце 80-х - начале 90-х гг. последовала волна контрреформ, усилившая раскол между обществом и государством.

5) Период 1904-1913 гг. характеризуется, с одной стороны, новым промышленным подъемом (среднегодовые темпы промышленного 68 
производства составили в 1909- 1913 гг. 8,9\%), увеличение сети железных дорог, быстрым ростом числа акционерных обществ и банков, созданием культуры сети монополий; попытками реформировать сельское хозяйство по западному образцу (реформы Столыпина), что позволило увеличить посевные площади в 63 губерниях с 81,2 млн десятин в 1904 г. до 138 млн десятин в 1913 г., улучшило техническое оснащение крестьянских и помещичьих хозяйств. Стоимость парка сельхозмашин выросла с 163 млн руб. в 1906 г. до 408 млн руб. в 1913 г.; в 1910 г. на экспорт было направлено 849 млн пудов хлеба. Это были признаки несомненного экономического подъема, сокращавшего отставание России от центров мирового экономического прогресса. Однако это отставание оставалось к концу этого периода еще весьма значительным.

В канун первой мировой войны Россия отставала по совокупному показателю экономического развития от США и Британии в 15 раз, Германии - в 10, Франции - в 4 раза [3]. К тому же в этот период резко обострились социально-политические противоречия, которые нашли выражение в позорном поражении в войне с Японией, «кровавом воскресенье» 9 января 1905 г., вооруженном восстании в Москве, волне правительственного террора и общественного разочарования в 1906-1908 гг. 


\section{2. Индустриализация и культурная детерминация социального развития в России}

Каковы же главные итоги первого полувекового индустриального цикла в истории России?

1. Россия сумела сравнительно быстро продвинуться по линии индустриального прогресса. Разрыв с промышленно развитыми странами был еще велик, но он сократился. Времени и сил на радикальное изменение полукрепостнических отношений в деревне не хватило. По переписи 1897 г. сельским хозяйством было занято 75\% населения, тогда как в промышленности и на железных дорогах — 11,3\%, в торговле - 4\%. В итоге Россия находилась в группе стран среднего уровня развития (Австро-Венгрия, Испания, Япония), лишь в 4 раза превышая уровень Индии [13].

2. Острота противоречий и национальные традиции обусловили лидерство России в мировом интеллектуальном прогрессе. При этом по уровню грамотности Россия все еще отставала от развитых стран. (Но доля грамотных с 1860 по 1897 гг. возросла с 7 до 21\%). Сформировавшаяся в России интеллектуальная элита охватывала практически все сферы духовной жизни: в науке ученые с мировым именем - Д.И. Менделеев, И.М. Сеченов, И.И. Мечников, И.П. Павлов, А.С. Попов, В.И. Вернадский, Г.В. Плеханов, Н.А. Бердяев, М.И. Туган-Барановский и др.; в литературе - И.С. Тургенев, Л.Н. Толстой, Ф.М. Достоевский, А.П. Чехов, М. Горький; в музыке композиторы «могучей кучки», П.И. Чайковский; в изобразительном искусстве - И.Е. Репин, М.А. Врубель, Н.К. Рерих; в вокальном искусстве Ф.И. Шаляпин, Л.В. Собинов. Вряд ли можно найти страну, в которой в короткое время было бы сконцентрировано столько ярких интеллектуальных звезд высокого класса. Сравнение можно провести только с эпохой Ренессанса в Италии. В этом парадокс истории: периоды расцвета науки и культуры не совпадают с пиками экономического подъема. Напротив, острота 
экономических и социальных противоречий подталкивает мысль к поиску новых нестандартных решений, путей выхода из кризиса.

3. Не менее острыми были социально-политические противоречия этого периода. Реформы двинули страну по капиталистическому пути. Но крупная буржуазия в союзе с иностранным капиталом захватила решающие позиции в экономике, при этом не имела достаточного политического опыта. Буржуазный демократический строй так и не сформировался. Подавляющую часть населения в 1913 г. составляли мелкие беднейшие хозяева (21,5\%), полупролетарии $(33,6 \%)$ и пролетарии $(19,6 \%)$, практически лишенные собственности. В социально-политической области Россия на столетие отставала от лидировавших в мировом историческом прогрессе стран. В стране, несмотря на революции, упорно возрождался общинный строй с его уравнительностью и консерватизмом, враждебным отношением к предпринимательству.

4. В первом индустриальном полувековом цикле наблюдалась повышенная открытость России внешнему миру. Это было нечто похожее на эпоху Киевско-Новгородской Руси и Петра I. За 40 лет (с 1860 по 1901 гг.) объем внешней торговли России увеличился в 7,5 раз. В этот период сложилась сырьевая структура экспорта: хлеб в нем составлял $51,6 \%$, другие продовольственные товары — 14,5\%, нефть, руда и лесные товары - 12,3\%. В импорте преобладали металлы, металлоизделия и химические продукты $21,2 \%$, промышленные товары и сырье для их изготовления - 33,8\%. В Россию активно устремился иностранный капитал: его доля в общем вложении капитала в 1860-1880 гг. составляла 47\%, а в производственных вложениях 72\%. Иностранный капитал, с одной стороны, ускорял индустриализацию страны, с другой стороны, он способствовал тому, что в российской модели индустриализации преобладали сырьевые отрасли тяжелой индустрии, железнодорожное строительство, а не потребительский рынок и легкая промышленность, как в Англии. 
Второй долгосрочный индустриальный цикл начался с глубочайшего общенационального кризиса и охватил примерно полвека (1914-1964 гг.) [83]. Здесь также можно выделить несколько крупных этапов. 1) 1914-1922 - время острейшего общегосударственного кризиса, который начался с участия в мировой войне, революций 1917 г., гражданской войны и завершился утверждением большевистского сценария развития России; 2) 1923-1934 время выбора различных вариантов социалистического пути - от либеральнонэповского до тоталитарно-бюрократического. Этот этап завершился ликвидацией либерально-рыночного варианта, уничтожением крестьянского хозяйства и значительной части интеллектуального потенциала страны, глубоким кризисом 1930-1933 гг.; 3) 1935-1952 — среднесрочный цикл, в течение которого путем террора и чисток укреплялась власть лидера, произошла Отечественная война, в которой была уничтожена значительная часть населения страны и ее национального богатства. После победы удалось в основном восстановить довоенный уровень, но с деформированной структурой экономики (преобладал военный сектор, подорваны были сельское хозяйство, потребительский сектор). Сформировался мировой социалистический лагерь ценой изоляции от остального мира; 4) 1953-1964 - попытка осуществить реконструкцию и оздоровление избранной социалистической модели с помощью хрущевских реформ, с «оттепелью» и подъемом в начале периода и очередным экономическим и социальным кризисом в конце, а также началом кризиса мирового социализма (венгерский кризис).

Каковы общие достижения и неудачи второго долгосрочного индустриального цикла, его вклад в исторический генотип России?

1. Оказавшись на острие глубокого мирового и национального кризиса, пройдя революцию и гражданскую войну, Россия избрала сценарий проведения дерзкого эксперимента: осуществления впервые в мире идеала социалистического общества. Ценой невероятных усилий и потерь она стала лидером мирового прогресса на несколько десятилетий. Затем обнаружилась - 
уже в 80-е - 90-е гг. - бесперспективность избранного пути. Урок России должен пойти на пользу культурному развитию человечества, когда оно будет выбирать не между капитализмом и социализмом (оба они уйдут в прошлое), а между индустриальной и постиндустриальной цивилизациями [43].

2. Второй полувековой цикл в корне изменил экономику России; в ней мало, что осталось от накопленного за несколько предшествовавших цивилизаций. Радикально изменилась воспроизводственная структура экономики: резко снизилась доля сельскохозяйственного производства (почти в шесть раз) и группы «Б» промышленности в валовом общественном продукте, тогда как доля производства средств производства увеличилась в 3,3 раза. Экономика России носила односторонний характер, с гипертрофированным развитием тяжелой и военной промышленности и слабым развитием отраслей, работающих непосредственно на потребности населения. Индустриальное могущество достигалось в основном за счет низкого жизненного уровня людей.

3. Была создана уникальная модель социально-политических отношений, отвечавшая тенденциям преодоления социальных и политических различий. Социальная структура была упрощена до предела, включала рабочий класс, колхозное крестьянство и трудовую интеллигенцию. Они были закрепощены, крестьяне - без паспорта и с учетом трудодней, рабочие и служащие - без права увольнения по собственному желанию. Сформировалась привилегированная партийно-государственная элита. Национальные различия были официально признаны, поддерживалась национальная культура и развивались ранее отсталые национальные окраины. Было провозглашено, что национальный вопрос решен окончательно и бесповоротно. Происходило смешение народов. Некоторые нации были подвергнуты насильственной депортации.

4. Идеология социализма провозгласила равенство и свободу личности, расцвет духовной сферы. Но эта сфера во многом оказалась жертвой казарменно-бюрократического строя. Интеллектуалы оказались особенно 
бесправными и гонимыми. Пресекались все попытки нестандартного, самостоятельного мышления. Несколькими волнами протекал процесс деинтеллектуализации общества: первая волна - уничтожение и изгнание части интеллигенции в годы гражданской войны, принудительная депортация за рубеж; вторая волна - серия процессов, начиная с шахтинского дела; третья волна - война и послевоенные репрессии; четвертая волна — миграция недовольных в 60-е и последующие годы. Конечно, ученые с именем были. Было даже свободомыслие, но под очень жестким контролем. Попытки реформации и закат социализма - таково основное содержание третьего полувекового цикла индустриальной цивилизации в России, который начался в 1964 г. и закончился в начале столетия.

В рамках этого крупного этапа можно выделить несколько среднесрочных циклов [23]. 1) 1964-1984 - неудачные попытки реформировать социализм, придав ему черты рыночной экономики. При этом сохранялись основы партийно-государственного монополизма. Это, в конечном счете, привело к очевидному для всех застою. Накапливались предпосылки для всеобщего кризиса; 2) с 1985 г. до середины 90-х гг. — попытки радикального изменения общества с помощью перестройки, которая неожиданно для инициаторов, но закономерно привела к развалу СССР, краху партийногосударственного монополизма и планового регулирования экономики, крушению социалистического идеала, всеобщему разброду и шатанию, взрыву хаоса, социальных и национальных конфликтов, мучительному поиску и лихорадочному, поспешному, но безуспешному перебору вариантов выхода из кризиса и будущего развития; 3) с середины 90-х годов до конца первого десятилетия двадцать первого столетия - мучительный выход из кризиса, постепенная кристаллизация новых идеалов будущего общества, вызревание предпосылок индустриальной цивилизации, определение места России и связанных с ней государств в мировом историческом прогрессе. Следовательно, 
основным содержанием третьего цикла стал кризис индустриальной и начало перехода к постиндустриальной цивилизации в России.

Какие тенденции наметились на новом витке исторической спирали?

1. Крушение социалистического идеала и поиск новых целей и ориентиров движения в будущее. Впрочем, это не означает, что сторонники социалистической идеи вдруг исчезли.

2. Развал модели тоталитарного государства, поиск новой модели политического и государственно-правового устройства общества. Во-первых, монопартийная система отошла в прошлое. На смену пришла утрированная многопартийность, больше похожая на хаос. В условиях хаоса, как известно, увеличивается опасность установления диктатуры. Во-вторых, уже четвертой в истории России национальной катастрофой стал распад СССР, резкое усиление локализма, сепаратизма, борьбы за приоритет национальных суверенитетов и местных интересов. Такие процессы наблюдались и при прежних национальных катастрофах. Достаточно вспомнить распад Российской империи, когда были провозглашены Шлиссельбургская, Кронштадтская, Казанская, дальневосточная и десятки других республик. Можно предположить, что эта тенденция к сепаратизму непременно сменится центростремительной, интеграционной. Россия в силу громадности своей территории, экономической мощи, богатства природных ресурсов, многовековой традиции не может сойти с геополитической арены, потерять лидерство в качестве одного из полюсов современного многогранного мира. Другое дело - изменение сферы и механизма реализации ее лидерства. Втретьих, радикально меняется сфера межнациональных отношений. Национальная идея стала перерастать в чувство национальной исключительности, в межнациональной исключительности. В-четвертых, развал государственности выразился в кризисе права, разгуле преступности, усилении влияния теневой экономики. Такое состояние характерно для переходного периода, что наблюдалось в XII-XIII вВ., и в «смутное время», и в начале XX в. Этот период занимает, как правило, два-три десятилетия [35]. 
3. Радикальные перемены произошли в экономическом строе России. Экономический строй, безусловно, более инерционен, чем социальнополитический. Утратило прежнее безраздельное господство государственной собственности. Однако наблюдается разгул самых грубых форм первоначального накопления капитала - «дикого» рынка - весьма неприятная, но неизбежная черта экономики переходного периода. На смену ей идет, как это известно из российского и зарубежного исторического опыта, стабилизация многоукладной экономики, где каждая форма собственности занимает адекватную ей нишу, а обмен осуществляется в упорядоченнолегализованных формах. Однако до этого еще немало лет.

4. Поворот к ренессансу гуманизма в постиндустриальной цивилизации начался с противоположной тенденции в переходный период. Это период кризиса науки, культуры, образования, нравственности, идеологии, дальнейшей деинтеллектуализации общества. Умственный труд быстро обесценивается, происходит утечка мозгов и талантов в коммерческую сферу и за границу. Кризис культуры несет угрозу многовековому культурному наследию России, теряются моральные ценности и вековые нравственные устои. Это отбрасывает общество на столетие назад. Духовные потери трудно восполнимы. Однако эти потери не являются необратимыми. Признаки новых подходов, возвращения интереса к знаниям и культуре различимы уже сейчас.

5. Меняется место России в мировом прогрессе. Россия не может сойти с мировой арены. Она обречена на лидерство, но уже иными, ненасильственными методами. Для восстановления ее роли необходимо добиться экономической и политической стабильности. Необходимо формирование новых идеалов и осознание своего места в изменяющемся мире. Но и мир должен осознать роль новой России.

Таким образом:

1. Особенности основных этапов историко-культурного развития России связаны с особенностями ее географического положения, национальным составом, историческими традициями и другими факторами. 
2. Россия (вернее то, что ей предшествовало) на два тысячелетия позже по сравнению с эпицентрами прогресса начала свой исторический путь. Это отставание заставляло ее двигаться быстрее, чтобы догнать ушедших вперед.

3. Движение на пути прогресса осуществлялось Россией спазматически. После периодов бурного прогресса следовал период расслабления и замедленного движения.

4. Крупными вехами на этом пути были национальные катастрофы переходных периодов: XIII-XIV вв. (феодальная раздробленность и татаромонгольское нашествие); конца XVI - начала XVII вв. («Великая смута»); начала XX в. (распад Российской империи). Сейчас пришло время очередной катастрофы: распад СССР и угроза распада России.

5. Будущее России и ее культуры зависит от того, какие тенденции возобладают на современном этапе - кризисные и дезинтеграционные или ренессансные и объединительные. Ближайшие годы должны показать, исчерпала ли Россия свой исторический потенциал или она сумеет сделать очередной рывок и встать в первый эшелон стран и народов, формирующих основы постиндустриальной цивилизации.

\section{Вопросы для самоконтроля}

1. Назовите структуру начальных учебных заведений России во II половине XIX века?

2. Кто такие западники и славянофилы и каковы их основные идеи по переустройству российского общества?

3. Дайте характеристику развития индустриальной цивилизации в России с 60-х годов XIX века до начала XXI века?

4. Назовите полувековые циклы развития современной истории России и дайте им краткую характеристику?

5. Какие тенденции культурно-исторического развития России возникли в конце XX начале XXI веков? 


\section{4. ФУНКЦИОНАЛЬНАЯ ОБЩНОСТЬ КУЛЬТУР И КУЛЬТУРНАЯ СПЕЦИФИКА}

\section{1. Сущность культурных ценностей и их место в межкультурной коммуникации}

C раннего детства каждый ребенок овладевает родным языком и усваивает культуру, к которой принадлежит. Это происходит в процессе общения с близкими и незнакомыми людьми, в домашней среде, с помощью вербальных и невербальных способов общения [5]. Категория ценности образуется в человеческом сознании путем сравнения разных явлений. Осмысливая мир, человек решает для себя, что для него представляется важным в жизни, а что нет, что существенно, а что несущественно, без чего он может обойтись, а без чего нет. В результате этого формируется его ценностное отношение к миру, в соответствии с которым все предметы и явления рассматриваются им по критерию важности и пригодности для его жизни.

Роль ценностей в жизни, как отдельного индивида, так и общества в целом чрезвычайно велика. В соответствии с ними происходит отбор информации в процессе общения, устанавливаются социальные отношения, формируются аффекты (эмоции и чувства), навыки взаимодействия и т.д. Таким образом, ценность не есть вещь, а есть отношение к вещи, явлению, событию, процессу и т.п. Ценности имеют огромное значение в любой культуре, поскольку определяют отношения человека с природой, социумом, ближайшим окружением и самим собой. Исходя из такого понимания, К. Клакхон и Ф. Стродбек определили ценности как «сложные, определенным образом сгруппированные принципы, придающие стройность и направленность разнообразным мотивам человеческого мышления и деятельности в ходе решения общих человеческих проблем».

Осваивая ценности окружающего мира, человек опирается на устоявшиеся в его культуре традиции, нормы, обычаи и постепенно формирует 
систему основополагающих и общепринятых ценностей, служащих ему руководством в жизни. На этой основе в каждой культуре складывается своя система ценностей, отражающая ее специфическое положение в мире. Система ценностей обыкновенно представляет собой иерархию, в которой ценности располагаются по нарастающей значимости. Благодаря этой системе обеспечиваются целостность данной культуры, ее неповторимый облик, необходимая степень порядка и предсказуемости.

Существуют ценности личного характера, ценности, присущие определенному полу или возрасту, ценности каких-либо больших и малых групп людей, различных эпох и государств и так далее, вплоть до общечеловеческих. По этой причине в науке принято все культурные ценности систематизировать на две основные группы. Во - первых, это совокупность выдающихся произведений интеллектуального, художественного и религиозного творчества. В эту группу включаются также выдающиеся архитектурные сооружения, уникальные произведения ремесла, археологические и этнографические раритеты. Во - вторых, к числу культурных ценностей были отнесены оправдавшие себя и доказавшие на практике свою эффективность принципы совместного сосуществования людей: нравы, обычаи, стереотипы поведения и сознания, оценки, мнения, интерпретации и пр., которые ведут к интеграции общества, к росту взаимопонимания между людьми, их комплиментарности, солидарности, взаимопомощи и т.д. Обе группы культурных ценностей на практике составляют «ядро» любой культуры и определяют ее неповторимый характер.

В процессе межкультурных контактов обнаруживается огромная разница между тем, как воспринимаются одни и те же ценности людьми разных культур. Среди громадного числа разнообразных восприятий, тем не менее, можно выделить группу таких, которые совпадают и по характеру оценок, и по содержанию. Такого рода ценности получили название универсальных или общечеловеческих. Их универсальный характер обусловливается тем, что 
основные черты таких ценностей базируются на биологической природе человека и на всеобщих свойствах социального взаимодействия. Так, например, нет ни одной культуры в мире, где оценивалось бы положительно убийство, ложь и воровство. В каждой культуре существуют лишь свои границы терпимости этих явлений, но общая их негативная оценка однозначна.

Рассмотрение культуры как системы ценностей логично ставит вопрос о формах их существования и сферах распространения. В культурной антропологии принято выделять четыре основные сферы культурных ценностей: быт, идеологию, религию и художественную культуру. В контексте межкультурной коммуникации из этих сфер наиболее важное значение имеет сфера быта, представляющая собой исторически первую сферу возникновения и существования культурных ценностей.

Несмотря на наличие идеологии, религии и искусства бытовая культура и сегодня остается основополагающей для формирования личности, поскольку это формирование начинается еще в детстве, когда человек не способен к освоению культурных ценностей идеологии, религии и искусства. Специфика бытовой культуры состоит в том, что она вырабатывает те ценности, которые имеют основополагающее значение для межкультурной коммуникации. Именно быт является хранителем исторической памяти культуры, поскольку он значительно устойчивее идеологии и религии и изменяется гораздо медленнее, чем они. Поэтому именно бытовая культура в большей степени содержит в себе ценности «вечные», общечеловеческие и этнические. Кроме того, именно бытовые ценности являются основой существования идеологии, религии и искусства. Нормы и ценности бытовой культуры являются самодостаточными. Это значит, что, пользуясь только ценностями бытовой культуры, человек может иметь устойчивые ориентиры для жизни в условиях соответствующей культуры. Дополнительное значение бытовой культуре при межкультурной коммуникации придает ее стихийный характер. Ценности бытовой культуры рождаются в процессе житейской практики и имеют утилитарную 
направленность. Поэтому они не нуждаются в обосновании и доказательстве, носители данной культуры воспринимают их как естественные и само собой разумеющиеся. Их оказывается вполне достаточно для приобщения человека к культуре [20].

Культурные ценности, как уже было отмечено, в жизни каждого человека имеют разное значение. Поэтому одни люди являются приверженцами ценностей коллектива, а другие - ценностей индивидуализма. Так, человек в США в первую очередь считает себя индивидом, а уж потом членом социума, в то время как во многих других странах, таких, как Япония, люди в первую очередь считают себя членом социума и только потом индивидом. Когда люди с такими разными ориентациями вступают в общение, особенно деловое, всегда возникают ситуации непонимания. Например, проводя деловые переговоры с японцами, американцы назначают сотрудника, ответственного за их подготовку и ведение, и, если переговоры пройдут успешно, этот сотрудник будет вознагражден. В японской фирме такое невозможно, там царит коллективная ответственность за результаты любого дела. Поэтому в Японии никогда не выделяют кого-либо из общей массы.

Какие ценности имеют для людей важное значение и обладают большим влиянием, а какие не принимаются во внимание - зависит от культуры. Их структура и значимость определяют своеобразие и особенности культуры. Большая часть особенностей собственной культуры, как правило, не осознается и воспринимается как само собой разумеющееся. Осознание ценностей своей культуры наступает лишь при встрече с представителями других культур, когда происходит взаимодействие разных культур, и обнаруживаются различия в их ценностных ориентациях. Именно в этих случаях возникают ситуации непонимания, растерянности, бессилия и раздражения, вызывающие чувство обиды, злости, отчуждения, оскорбления [10].

Жизнь человека в обществе себе подобных всегда подчинена определенным правилам, которые составляют существенную часть его образа 
жизни. В соответствии с этими правилами любая культура имеет собственное представление о «плохом» и «хорошем» поведении. В каждой культуре формируется система долженствовании и запретов, которые предписывают, как обязан человек поступать в той или иной ситуации, или указывают ни в коем случае чего-то не делать. Все это означает, что общение между людьми облечено в различные формы, подчинено тем или иным условностям и законам. Различные способы человеческого общения также диктуются культурными нормами, которые предписывают, как должны общаться или обращаться друг к другу младшие и старшие по возрасту или чину, мужчины и женщины, законопослушные граждане и преступники, туземцы и иностранцы и т.д. При этом зачастую официальные законы играют меньшую общественную роль, чем правила и запреты, сложившиеся в значительной мере стихийно.

Практически с самого начала культурной деятельности человека возникает потребность в регулировании его поведения и общения с другими людьми. Необходимость этого вызвана тем, что материальные продукты культуры, которые создаются людьми, лишь показывают границы их возможностей, но они не определяют, как должны действовать люди в различных отношениях между собой. Поэтому вместе с созданием ценностей культуры стали одновременно формироваться также требования к поведению человека, которые регулировали как распределение этих ценностей, так и разнообразные отношения между людьми. Первоначально они представляли собой правила, регулирующие человеческое поведение, позднее в науке они получили название норм. Изначально нормы служили указателями на то, где, как, когда и что должны были делать люди в повседневной жизни. Различные нормы имели разную степень влияния и значения в поведении людей, и те из них, которые приобретали наибольшее влияние, становились общепринятыми [79]. 


\section{2. Культурная дистанция, конфликт культур и культурные традиции}

На протяжении всей истории человечества различными культурами было создано огромное количество самых разнообразных норм поведения и общения. В зависимости от способа, характера, цели, сферы применения, границ распространения, строгости исполнения все многообразие поведенческих норм было разделено на следующие виды: традиции, обычаи, обряды, законы, нравы.

Одним из первых регуляторов человеческого поведения стали нравы, которые были предназначены регулировать повседневное поведение людей, способы реализации ценностей, оценивать различные формы их отношений и т.д. Из всех культурных норм нравы являются наиболее подвижными и динамичными, поскольку призваны регулировать текущие события и поступки. Нравы - это моральные оценки допустимости тех или иных форм как собственного поведения, так и поведения других людей. Под действие этого вида культурных норм попадают такие формы поведения, которые бытуют в данном обществе и могут быть подвергнуты нравственной оценке. В силу такого своего характера нравы не предполагают немедленного их практического исполнения, а ответственность за их нарушение в целом значительно меньше, чем во всех других нормах. Эта ответственность носит относительный характер, поскольку наказание за нарушение нравов может быть разным - от неодобрительных взглядов до смертной казни, но наиболее распространенным наказанием в этом случае является устное порицание. Например, если вы громко чавкаете во время обеда в обществе, то, возможно, в вашу сторону будут направлены лишь неодобрительные взгляды людей, которые вас слышат. Но в некоторых культурах, наоборот, считается нормой «потягивать» свой суп, и эта манера не вызывает никаких реакций окружающих [31]. 
Среди других видов культурных норм наиболее распространенными и влиятельными являются обычаи - общепринятые образцы действий, предписывающие правила поведения для представителей одной культуры. Влияние обычаев, главным образом, распространяется на область частной жизни людей. По своему назначению они призваны регулировать взаимоотношения и коммуникации внешнего характера, то есть отношения с близкими и дальними родственниками, со знакомыми и соседями, публичное поведение человека за пределами собственного дома, бытовой этикет со знакомыми и незнакомыми людьми и др.

Регулятивная роль обычаев заключается в том, что они предписывают строго установленное поведение в определенных ситуациях. Обычаи возникли в незапамятные времена как традиционные формы поведения, благодаря которым обеспечивалась культурная стабильность. В такой их роли было заинтересовано все общество, и оно стремилось их сохранять и культивировать. Поэтому многие обычаи оставались на протяжении веков неизменными [28].

В каждой культуре формируется своя система обычаев, распространяющаяся на все стороны повседневных отношений. Тот или иной обычай всегда связан с соответствующей специфической ситуацией. Поэтому характер и основные черты обычаев соответствуют образу жизни общества и его социально - сословной структуре. По этой причине одинаковые, на первый взгляд, обычаи в разных культурах приобретают совершенно разное содержание. Примерами здесь могут служить различия в разных культурах по отношению к свадебным обрядам и половым контактам.

Становление различных регуляторов поведения человека шло одновременно с развитием и усложнением его взаимоотношений $\mathrm{c}$ окружающим миром. По мере накопления культурного и социального опыта стали возникать устойчивые формы поведения, которые предписывали наиболее рациональные действия при взаимоотношениях различных групп людей в соответствующих ситуациях. Имеющие рациональный характер и 
многократно проверенные на практике, они стали передаваться от поколения к поколению, что придало им традиционный характер и породило новый вид культурных норм - традицию. Первоначально это слово обозначало «предание», подчеркивавшее наследственный характер соответствующих культурных явлений. В настоящее время назначение традиций сводится к регуляции межличностных и межгрупповых отношений, а также передаче социального опыта от поколения к поколению. Фактически традиция - это своего рода устные «культурные тексты», аккумулирующие в себе совокупность образцов социального поведения, сложившиеся формы социальной организации, регуляции и коммуникации [30].

Традиции имеют место в самых разных областях человеческой жизни. Взятые вместе, они представляют собой устойчивую систему поведения человека в самых разных сферах жизни и в разных ситуациях, выполняя при этом свою особую роль. Основной особенностью традиций является акцент на использование таких образцов и моделей поведения, следование которым служит необходимым условием общественной жизни каждого человека. Этот вид социальной регламентации исключает элемент мотивации поведения: нормы, составляющие традицию, должны выполняться автоматически. Представители данной культуры в этом случае должны твердо следовать установившейся модели поведения, основываясь только на интуитивном убеждении, что «так поступали наши предки», «так принято» и т.п.

Автоматическое следование традиции на практике представляет собой простое соблюдение привычных норм и требований к поведению представителей какой-либо культуры. Возьмем для примера процедуру совершения покупок. В европейских странах при покупке товара отношения продавца и покупателя определяются устойчивыми ценами. В редких случаях здесь уместен торг, но он скорее исключение, а не правило. В то же время именно торг является необходимым атрибутом процедуры покупки в арабских странах. Там торговля является одновременно процессом общения между 
участниками и поэтому превращается в увлекательную и эмоциональную форму коммуникации. Другим примером может служить традиция приглашения на обед друзей и знакомых, которая существует во многих странах Европы и Азии. Однако в Азии сразу после обеда принято попрощаться и уходить. Если кто-то поступает не так, то это значит, что он еще хочет есть. И, напротив, если так поступить в Европе или Северной Америке, то это будет расценено как невоспитанность и неуважение. Такое поведение будет означать, что вы пришли в гости только пообедать [57].

Разновидностью традиции является обряд, который представляет собой массовое выражение религиозной или бытовой традиции. Его главной отличительной чертой является не избирательность, а массовость, поэтому влияние обрядов не ограничивается какой - то социальной группой, оно относится ко всем носителям данной культуры. Как правило, обряды сопровождают важные моменты человеческой жизни, связанные с рождением, свадьбой, вступлением в новую сферу деятельности, переходом в другую возрастную группу, смертью. Однако наиболее известными и распространенными являются религиозные обряды, особенно связанные с использованием пищи. Достоверно известно, что во многих древних религиях жертвоприношения совершались предметами пищи, а в христианстве обряд причащения совершается хлебом и вином. Это неслучайно. Поскольку еда является первоосновой физического существования человека, то практически в любой культуре она обретает мистическое и символическое значение. На самых ранних стадиях развития культуры процесс потребления пищи значил для человека не только утоление голода, но и приобщение к окружающему миру: так, сила съеденного животного как бы переходила к съевшему его человеку, а злаки и ягоды давали символическое приобщение к силам земли. Подобного рода символические значения и лежат в основе многих религиозных традиций жертвоприношения и таинств. 
Наряду с традициями и обычаями неотъемлемой частью культуры любого народа является право, которое представляет собой систему обязательных правил поведения, санкционированных государством и выраженных в определенных нормах. Прообразом права были запреты (табу) в поведении человека. Право представляет собой совместный договор людей о правилах поведения. Эти правила являются общеобязательными для всех, a их исполнение контролируется государством. Действие права распространяется на все сферы общественной жизни: они определяют производство и распределение продуктов между людьми, регулируют отношения между ними, регламентируют контакты и связи между народами.

Своим строго нормативным характером право отличается от обычаев, которые представляют собой распространенную практику поведения, типичные действия, то, что происходит по обыкновению. Но, несмотря на характерные различия, право и обычай связаны между собой. Например, по китайскому закону муж имел право в случае смерти жены на повторный брак. Это право фиксировало обычай и поощряло такую практику поведения как нечто обычное и распространенное. Напротив, повторный брак вдовы осуждался конфуцианскими нормами. Считалось, что повторным браком жена лишает душу покойного мужа спокойствия в загробном мире. Но эта норма не стала обычаем, практикой поведения, и повторные браки вдов случались довольно часто [55].

Сравнительный анализ норм права в разных культурах показывает, что они весьма существенно отличаются у разных народов. В основе этих отличий лежит, как правило, различное понимание справедливости.

Наконец, вероятно, наиболее важным и значимым регулятором поведения отдельного человека и отношений между людьми является мораль, которая призвана регулировать обыденные отношения людей, их ценностные ориентации, интерпретации различных явлений культуры, правила человеческого поведения и т.п. Необходимость морали как регулятора 
поведения обусловлена тем, что каждый человек так или иначе ведет себя, совершает какие-либо поступки, действия по отношению к окружающему миру и, прежде всего по отношению к другим людям. При этом в его поведении проявляются особенности характера, темперамента, взгляды, вкусы, привычки, эмоции, чувства и т.д. Сопоставляя поведение какого-либо человека с определенными культурными ценностями общества, принято говорить о поведении нормальном либо отклоняющемся. Нормальным считается поведение, соответствующее нормам, которые выработало и которых придерживается данное общество. Оно включает определенные манеры, общепринятые способы общения, обращение с окружающими, которые могут быть подвергнуты нравственной оценке. Так, например, во многих культурах считается недопустимым ходить по улицам нагим, оскорблять старших, бить женщин, обижать слабых, издеваться над инвалидами и т.п.

Таким образом, различные виды культурных норм пронизывают практически все сферы человеческой жизнедеятельности. Их спектр довольно широк - от простых запретов до сложной системы социальных институтов. В процессе развития культуры некоторые из них сами приобрели статус культурных ценностей, а обязательность их исполнения в общественном сознании современного общества воспринимается не только как простая повинность, но и как осознанная необходимость, внутреннее убеждение человека. Нормативные регуляторы культурных норм могут быть как разрешительными, так и запретительными. Однако с их помощью регулируются, координируются действия отдельных личностей и человеческих групп, вырабатываются оптимальные пути решения конфликтных ситуаций, предлагаются рекомендации для решения разнообразных жизненных вопросов.

\section{Организационная (корпоративная) культура}

Понятие культуры стало примеряться по отношению к организации не более 60 - 70 лет тому назад. Это произошло в результате осмысления исследований специалистов по управлению, психологов, социологов, и 
представителей других научных дисциплин, выполненных в области социальных отношений в XX столетии.

Уже с середины 30 - х годов XX века начали распространяться различные теории о сущности культуры организации, а в настоящее время интерес к концепции культуры организации еще более вырос, причем во многих областях науки. Причина этого заключается в наличии, по выражению философа А.С. Арсеньева, «конвергенции, сближения или схождения всех учений и представлений» людей об организации.

Интересно, что согласно одной из версий понятие «организационная культура» было введено в 20 - е гг. прошлого века выдающимся советским ученым, руководителем Центрального института труда при ВЦСПС СССР А. Гастевым, который высказывался, что «культура производительности человека является предпосылкой его трудовой культуры».

Теоретическое и концептуальное осмысление понятия культуры организации продолжилось с конца 30 - х гг. в трудах Ч. Барнарда и Г. Саймона, которые во многом предвосхитили в понятии «организационная мораль» основные черты понятия «организационная культура». Затем группа американских специалистов, работавшая в 1949 - 1950 годы в Японии на примере целого ряда предприятий доказала высочайшую эффективность философии «менеджмента сотрудничества», концептуальные основы которой были разработаны У. Демингом [47].

Эмпирическое изучение организационной культуры впервые было проведено на некоторых средних и крупных предприятиях США и Канады в 50 - х гг. прошедшего столетия американским ученым М. Далтоном. Он обобщил результаты своих исследований в книге «Человек, который управляет». Практически одновременно с Далтоном, группа английских социологов из Тавистокского института провела исследование организаций как культурных систем. Результаты обоих исследований подтвердили существование внутри организаций особой сущности, влияющей на мотивацию работников. 
В конце 1960 годов в США публикуется ряд трудов, например, Д. Хэмптона, X. Трайса, в которых уделялось внимание разнообразным принятым традициям, обрядам и ритуалам. То есть ученые уже начинают выявлять и оценивать значение внешних признаков культуры.

В начале 80 - х годов в ряде исследований У. Оучи, Т. Питерса и Р. Уотермена - мл., Т. Дила и А. Кеннеди на примере крупнейших корпораций США были убедительно продемонстрированы преимущества компаний с сильной идеологией. Все это резко повысило интерес к проблеме организационной культуры.

В это время в мире, согласно исследованию, проведённому институтом Бателле в 1984 году, всё более исключаются такие, прежде общепризнанные ценности, как «дисциплина, послушание, иерархия, достижения, карьера, достаточность, власть, централизация». Им на смену приходят другие «самоопределение, участие, коллектив, ориентирование на потребности, раскрытие личности, творчество, способность идти на компромиссы, децентрализация» [56].

Так как культура организации является «сложносоставной» дисциплиной, действующей на стыке теории управления, социологии и психологии организаций и ряда других дисциплин, то основоположника нового подхода назвать сложно, но чаще всего им считается выдающийся ученый Т. Парсонс. В описании организации как социальной системы Т. Парсонс указывает, что существует «культурная система, представляющая собой символически организованные образцы, основанные на способности человека говорить и передавать опыт негенетическим путем». Однако теория Т. Парсонса была достаточно сложна для большинства менеджеров - практиков, поэтому большее распространение получил вышедший в начале 90 - х годов труд Э. Шейна «Организационная культура и лидерство» [85].

Первый, поверхностный уровень организационной культуры проявляется через артефакты. Под артефактами Шейн понимает конкретные 
продукт культуры (устные, письменные, предметы). Например, артефактом фирмы может быть устав, значок, территория, газета, фирменная одежда для персонала и т.д. чем больше у компании истории, зафиксированной в артефактах, тем мощнее организационная культура фирмы.

Второй уровень разделен волнистой чертой, как «айсберг». Видны нормы и ценности, которые находятся над волнистой чертой. Это декларируемые нормы и ценности. Однако, в компании очень часто существует «двойная мораль», те правила, о которых нигде не говорят, но все знают, что можно делать, а что - нельзя. Это латентные, то есть скрытые для стороннего наблюдателя нормы, которых уже не видно снаружи.

Третий, глубинный уровень модели Шейна показывает, что все артефакты и нормы, и правила являются лишь надстройкой, которая определяется поведением людей. В американских учебниках под термином «поведение» понимают реальное базовое допущение, которое мы себе разрешаем и принимаем. Под термином «мы» понимают, во-первых, создателя фирмы, а во - вторых, ее персонал (в терминах Шейна). По мнению психологов, поведением человека на 90\% руководит его бессознательное, которое находит выражение в базовых верованиях. Они же, в свою очередь отражаются в архетипах. Архетипы - это базовые способы поведения, которые определяются национальной культурой.

Можно выделить и другие причины популярности темы организационной культуры на Западе. У Америки появился конкурент в лице страны с культурой противоположной западному типу - Японии. Когда теоретики менеджмента обратили внимание на культуру японских фирм, они увидели в ней то объединяющее начало, которое способно интегрировать интересы самых разных работников, идейно сплачивать менеджеров и рабочих, а в конечном итоге способствовать росту производительности труда и экономической эффективности компании. 
Однако проблемы культуры организации рассматривались не только на Западе. В нашей стране проблемам организационной культуры уделялось не меньше внимания. В период с 20 - х годов до начала перестройки нашей стране было выпущено множество книг в рамках научной организации труда, посвященных советской формулировке организационной культуры - «культуре производства и труда» и «качеству трудовой жизни». В данных работах подробно изучалось влияние на производительную работу таких факторов, как идеология, психологический климат, воздействие коллектива на личность, роль лидерства и прочее. Недостатками того периода было то, что работы во многом идеологизированы и опирались на вненаучную аргументацию. Многое из работ того времени актуально и поныне именно для отечественных предприятий: Успешные руководители современных российских предприятий вместо слепого копирования западных методик, все чаще обращаются к гигантской базе знаний, накопленных в советские годы.

Современными российскими авторами, активно обсуждающими проблемы организационной культуры, являются А. Пригожина и В. Спивак, которые первыми выпустили отдельную книгу, посвященную культуре организации, где проводится попытка отчасти переложить теорию Э. Шейна применительно к российской действительности.

Интерес российской общественности к феномену организационной культуры можно проследить по росту количества публикаций в прессе с 1991 по 2004 годы. В 2005 году в ведущих периодических изданиях страны было опубликовано около 1400 статей на данную тему, предположительно, что в 2006 году эта цифра удвоилась [62].

Авторы, характеризующие культуру компании, обычно используют один из двух терминов: организационная или корпоративная. Хотя большинство работ, посвященных как организационной, так и корпоративной культуре по смыслу одинаковы, отдельные ученые вводят разделение этих понятий. 
Понятия «организационная», «корпоративная» и «предпринимательская» культуры при определенных допущениях синонимичны.

Питтерс и Уотермен считают, что организационная культура - это система разделяемых ценностей, которые проявляются через различные культурные артефакты: истории, мифы и т.д. Это то, как люди работают и взаимодействуют. Ценности определяют поведение людей в организации. Нормы - это неписанные правила поведения. Главное назначение корпоративной культуры - это сплочение трудового коллектива вокруг общих ценностей и достижение корпоративной миссии.

Наличие общих целей, ценностей и задач создает людскую общность. Изучая высокоэффективные рабочие группы, психолог Абрахам Маслоу выявил, что их отличало общее понимание целей и задач. Он выделил «высокосинергичные» и «низкосинергичные» сообщества.

В результате исследования, проведенного Б. Рубеном, в качестве необходимых способностей для успешной работы в многонациональном окружении были выделены следующие навыки: уважение; терпимость к неопределенности; приверженность принципу «не судите, да не судимы будете»; умение формулировать любое высказывание как личную, а не общепринятую точку зрения; эмпатия; настойчивость.

Идентификация с основными корпоративными ценностями помогает работникам примириться с теми неизбежными жертвами, которые они приносят ради того, чтобы стать членами организации. Они постепенно начинают принимать, а затем и разделять ценности организации. Организация, в свою очередь, старается оправдать эти издержки, создавая свои корпоративные ценности в соответствии с высшими человеческими ценностями, например, декларируя служение обществу в виде улучшения качества своей продукции или услуг [60].

Подлинная самоподдерживающаяся и саморазвивающаяся система обязана иметь большое число степеней свободы. Это позволяет ей, не теряя 
фокуса, подстраиваться под внешние и внутренние изменения наиболее адекватным образом. Фокусы развития и поддержания, в рамках корпоративной культуры, задаются такими средствами, как Цель компании, Миссия компании, Девиз компании, Корпоративные стандарты. Культура компании предусматривает ряд факторов, делающих ее функциональной организацией [71]:

- Строгие правила поведения (общий язык, терминология, ритуалы, выражающие почтение и манеру поведения).

- Нормы (поведенческие стандарты, принятые масштабы работы).

- Доминирующие ценности (главные ценности, выдвигаемые организацией - например, качество продукта, низкий уровень прогулов, высокая эффективность).

- Философия компании (политика по отношению к сотрудникам и клиентам).

- Правила (строгий внутренний распорядок организации).

- Климат организации (общее чувство, создаваемое обстановкой, тем как проходит общение работников между собой, с клиентами или посетителями).

Например, стилем компании, может быть, правило о продвижении сотрудников по возрастному принципу, а ее философией - удовлетворение, как потребностей клиентов, так и профессиональных потребностей работников компании.

Ведущие западные теоретики и практики в управлении определяют вид оргкультуры по трем показателям: финансы; производство; психология.

Сильная оргкультура дает следующие эффекты [86]:

- финансовые показатели: рост прибыли,

- производственные показатели: рост продуктивности, инновации продуктов 
- психологические показатели: адекватная адаптация к окружающей среде, лояльность персонала, высокая степень удовлетворенности работой, высокая самооценка персонала, отсутствие напряженности между управленцами разных уровней иерархии, отсутствие симптомов стресса у работников

Особое значение в этой культуре имеют такие личностные качества как гибкость, восприимчивость, терпимость, умение работать в команде. Круг проблем межкультурной коммуникации охватывает время, место и целую систему отношений субъекта, включающей отношение к жизни (положительное/отрицательное); к стране (патриотизм/инфобия); к работе (преданность/критицизм); к полу/сексу (феминизм/сексизм); к деньгам (частная собственность/уравнение всех) и т.д.

Например, отношение ко времени в англоязычной корпоративной культуре - время в этой культуре является своеобразной системой информации. Отношение к жизни в Западной культуре характеризуется оптимизмом, культом успешности деятельности. Элементом западной культуры является также «светская беседа», служащая целям согревания отношений между людьми, особенно при первой встрече, снятию напряжения. Это способ, при помощи которого можно добиться значительных успехов в ходе деловых переговоров.

Жестким правилом в отношении является культурный запрет на критику страны, президента, руководства фирмы и своего непосредственного начальника, особенно перед иностранцами, посторонними людьми. Кстати, в рамках отечественной культуры делового общения критические высказывания в отношении «власть предержащих» не являются чем - то исключительным, а в некоторых случаях даже поощряются.

Можно предложить много примеров отношения к деньгам и образованию. Интересно, что в русской культуре в отличие от англо американской, образование никогда не рассматривалось как материальная 
ценность. В отношении к деньгам в нашей стране распространен эгалитаризм, двойной стандарт [27].

Существенные различия обнаруживаются и в культурном отношении к полу. В странах западной культуры Россия считается сексистской страной. В данном контексте особое внимание уделяется интонации. Должны быть абсолютно исключены «сексистские» элементы в деловой коммуникации провокационные интонации и т.п., которые указывают на непрофессиональный подход к делу.

С точки зрения аксиологии, ценности представляют собой свойства предмета удовлетворять определенные потребности отдельного человека или группы.

В силу социального неравенства, существующего как в обществе, так и в любой организации, ценности среди людей распределяются неравномерно. Именно на неравном распределении ценностей строятся отношения власти и подчинения, все виды экономических отношений, отношения дружбы, партнерства и т.д. Распределение ценностей в социальной группе, например, среди сотрудников компании, социологи называют ценностным образом данной группы или организации.

Корпоративные ценности и нормы могут быть представлены в следующем виде [14]:

- предназначение организации (высокий уровень технологии; качество; лидерство в отрасли; преданность духу профессии; инновационная деятельность и другие);

- значение различных руководящих должностей и функций (важность руководящих постов, роли и полномочия отделов и служб);

- обращение с людьми (забота о людях и их нуждах;

- беспристрастное отношение и фаворитизм;

- привилегии; уважение к индивидуальным правам;

- обучение и возможности повышения квалификации; 
- карьера; справедливость при оплате;

- мотивация людей);

- организация работы и дисциплина (добровольная или принудительная дисциплина; гибкость в изменении ролей; использование новых форм организации работы и другое);

- стиль руководства и управления (стили авторитарный, консультативный или сотрудничества; использование целевых групп; личный пример; гибкость и способность приспосабливаться);

- процессы принятия решений (кто принимает решение, с кем проводятся консультации; индивидуальное или коллективное принятие решений; необходимость согласия, возможность компромиссов и т.д.);

- распространение и обмен информацией (информированность сотрудников; легкость обмена информацией);

- характер контактов (предпочтение личным или письменным контактам; жесткость или гибкость в использовании установившихся каналов служебного общения; значение, придаваемое формальным аспектам; возможность контактов с высшим руководством; применение собраний; кто приглашается и на какие собрания; нормы поведения при проведении собраний);

- характер социализации (кто с кем общается во время работы, и после работы; существующие барьеры; особые условия общения);

- пути разрешения конфликтов (желание избежать конфликта и идти на компромисс; предпочтение применения официальных или неофициальных путей; участие высшего руководства в разрешении конфликтных ситуаций и т.д.);

- оценка эффективности работы (реальная или формальная; скрытая или открытая; кем осуществляется; как используются результаты).

Стремление к общим ценностям способно объединять людей, заключенных в соответствующие рамки организации, в формальные коллектив и неформальные группы для достижения поставленных целей. 
Все элементы корпоративной культуры необходимо учитываются в профессиональном поведении, где необходимо быть дружелюбным, открытым, не обозначать свое различное отношение к коллегам. А о чем же тогда говорится в сотнях и сотнях определений, призванных охарактеризовать нечто, выдаваемое за организационную культуру? Полагаем, что это абсолютно очевидно. Речь идет о личной культуре человека. Это он усваивает «символы, церемонии и мифы», формирует «комплексы убеждений и ожиданий, установки и предположения», использует привычные «образы мышления и способы действия» [2].

В настоящее время определяются два выраженных стиля корпоративной культуры - предпринимательская оргкультура и партисипативная культура [21]:

\section{Предпринимательская организационная культура:}

- решающий фактор успеха организации - инициатива самих работников, поэтому основной ресурс эффективности организации - ее настойчивые и агрессивные сотрудники, необходимо найти таких людей и постоянно сохранять над ними контроль;

- работники свободны в своих действиях пока делают «правильные» вещи, то есть обеспечивают максимальную прибыль;

- наиболее эффективный способ мотивации работников - это вызов, который открывает хорошую возможность для их самореализации, вызов должен соответствовать потенциалу работников и возможному вознаграждению;

- ответственность и риск принимаются на себя самими работниками, в организации царит дух внутренней состязательности (конкуренции).

Партисипативная организационная культура (культура «участия», команды):

- общность ценностных установок, приоритет общекомандных целей и взаимодополнительность членов команды; 
- люди способны гибко сочетать свои цели с целями команды. если последние четко оформлены;

- основные принципы взаимодействия:

- активное участие всех членов команды в анализе проблем и перспектив, планировании совместных действий, оценке и самооценке полученных результатов и индивидуальных вкладов в общекомандную работу;

- горизонтальные коммуникации между членами команды, постоянное самообразование всех членов команды.

Полная идентификация сотрудника с компанией означает, что он не только осознает идеалы компании, четко соблюдает правила и нормы поведения в организации, но и внутренне полностью принимает корпоративные ценности. В этом случае культурные ценности организации становятся индивидуальными ценностями сотрудника, занимая прочное место в мотивационной структуре его поведения [17].

\section{Вопросы для самоконтроля}

1. Что такое ценности для человека? Какие виды ценностей существуют?

2. Что такое ценности культуры?

3. Назовите известные Вам культурные обычаи?

4. Что такое нормы и традиции?

5. Что собой представляет организационная культура?

6. Назовите уровни организационной культуры и дайте им характеристику?

7. Что такое корпоративные ценности? 


\section{5. ДИАЛОГ КУЛЬТУР И СОЦИАЛЬНЫЕ КОММУНИКАЦИИ}

\section{1. Культурная идентичность, вторичная адаптация/социализация, инкультурация}

Культурные последствия расширяющихся контактов между представителями разных стран и культур выражаются среди прочего и в постепенном стирании культурной самобытности. Особенно это очевидно для молодежной культуры, которая носит одинаковые джинсы, слушает одну и ту же музыку, поклоняется одним и тем же «звездам» спорта, кино, эстрады. Однако со стороны более старших поколений естественной реакцией на этот процесс стало стремление сохранить существующие особенности и отличия своей культуры. Поэтому сегодня в межкультурной коммуникации особую актуальность имеет проблема культурной идентичности, то есть принадлежности человека к той или иной культуре [13].

Понятие «идентичность» сегодня широко используется в этнологии, психологии, культурной и социальной антропологии. В самом общем понимании оно означает осознание человеком своей принадлежности к какой либо группе, позволяющее ему определить свое место в социокультурном пространстве и свободно ориентироваться в окружающем мире. Необходимость в идентичности вызвана тем, что каждый человек нуждается в известной упорядоченности своей жизнедеятельности, которую он может получить только в сообществе других людей. Для этого он должен добровольно принять господствующие в данном сообществе элементы сознания, вкусы, привычки, нормы, ценности и иные средства общения, принятые у окружающих его людей. Усвоение всех этих проявлений социальной жизни группы придает жизни человека упорядоченный и предсказуемый характер, а также невольно делает его причастным к какой-то конкретной культуре. Поэтому суть культурной идентичности заключается в осознанном принятии человеком 
соответствующих культурных норм и образцов поведения, ценностных ориентации и языка, понимании своего «я» с позиций тех культурных характеристик, которые приняты в данном обществе, в самоотождествлении себя с культурными образцами именно этого общества [11].

Культурная идентичность оказывает определяющее влияние на процесс межкультурной коммуникации. Она предполагает совокупность определенных устойчивых качеств, благодаря которым те или иные культурные явления или люди вызывают у нас чувство симпатии или антипатии. В зависимости от этого мы выбираем соответствующий тип, манеру и форму общения с ними.

Интенсивное развитие межкультурных контактов делает актуальной проблему не только культурной, но и этнической идентичности. Это вызвано целым рядом причин [18]. Во - первых, в современных условиях, как и раньше, культурные формы жизнедеятельности с необходимостью предполагают принадлежность человека не только к какой - либо социокультурной группе, но и к этнической общности. Среди многочисленных социокультурных групп наиболее стабильными являются устойчивые во времени этносы. Благодаря этому этнос является для человека самой надежной группой, которая может обеспечить ему необходимую безопасность и поддержку в жизни.

Во - вторых, следствием бурных и разносторонних культурных контактов становится ощущение нестабильности окружающего мира. В этих обстоятельствах все больше людей (даже молодых) начинают искать поддержку в проверенных временем ценностях своего этноса, которые в данных обстоятельствах оказываются самыми надежными и понятными. Через осознание своей принадлежности к этносам люди стремятся найти выход из состояния социальной беспомощности, почувствовать себя частью общности, которая обеспечит им ценностную ориентацию в динамичном мире и защитит от больших невзгод.

В - третьих, закономерностью развития любой культуры всегда была преемственность в передаче и сохранении ее ценностей, так как человечеству 
необходимо самовоспроизводиться и саморегулироваться. Это во все времена происходило внутри этносов путем связи между поколениями.

Содержание этнической идентичности составляют разного рода этносоциальные представления, разделяемые в той или иной степени членами данной этнической группы. Эти представления формируются в процессе внутрикультурной социализации и во взаимодействии с другими народами. Значительная часть этих представлений является результатом осознания общей истории, культуры, традиций, места происхождения и государственности. В этносоциальных представлениях отражаются мнения, убеждения, верования, идеи, которые получают свое выражение в мифах, легендах, исторических повествованиях, обыденных формах мышления и поведения.

Этническая идентичность - это не только принятие определенных групповых представлений, но и готовность к сходному образу мыслей и разделяемые этнические чувства. Она также означает построение системы отношений и действий в различных межэтнических контактах. С ее помощью человек определяет свое место в полиэтническом обществе и усваивает способы поведения внутри и вне своей группы [22].

Рассматривая коммуникативные процессы как динамичную социокультурную среду, благоприятную для порождения и распространения различного рода образцов поведения, типов взаимодействия, следует помнить, что главными субъектами культуры являются люди, находящиеся в тех или иных отношениях друг с другом. В содержании этих отношений значимое место занимают представления людей о самих себе, и эти представления зачастую весьма существенно различаются от культуры к культуре. Каждый человек является носителем той культуры, в которой он вырос, хотя в повседневной жизни он этого обычно не замечает. Специфические особенности своей культуры он воспринимает как данность. Однако при встречах с представителями других культур, когда эти особенности становятся очевидными, люди начинают осознавать, что существуют также другие формы 
переживаний, виды поведения, способы мышления, которые существенно отличаются от привычных и известных. Разнообразные впечатления о мире трансформируются в сознании человека в идеи, установки, стереотипы, ожидания, которые становятся для него регуляторами поведения и общения. Через сопоставление и противопоставление позиций различных групп и общностей в процессе взаимодействия с ними происходит становление личной идентичности человека, которая представляет собой совокупность знаний и представлений человека о своем месте и роли как члена социальной или этнической группы, о своих способностях и деловых качествах.

Сущность личной идентичности раскрывается наиболее полно, если обратиться к тем общим чертам и характеристикам людей, которые не зависят от их культурной или этнической принадлежности [36].

В определенной степени межкультурную коммуникацию можно рассматривать как взаимоотношение противостоящих идентичностей, при котором происходит включение идентичностей собеседников друг в друга. Таким образом, неизвестное и незнакомое в идентичности собеседника становится знакомым и понятным, что позволяет ожидать от него соответствующих типов поведения и действий. Взаимодействие идентичностей облегчает согласование отношений в коммуникации, определяет ее вид и механизм. Так, на протяжении долгого времени «галантность» служила основным типом отношений между мужчиной и женщиной в культурах многих народов Европы. В соответствии с этим типом происходило распределение ролей при общении полов (активность мужчины, завоевателя и обольстителя, наталкивалась на реакцию противоположного пола в форме кокетства), предполагало соответствующий сценарий общения (интриги, уловки, обольщения и т.п.) и соответствующую риторику общения. Такого рода отношение идентичностей служит фундаментом коммуникации и оказывает влияние на ее содержание. 
Вместе с тем тот или иной тип идентичности может создавать препятствия для коммуникации. В зависимости от идентичности собеседника стиль его речи, темы общения, формы жестикуляции могут казаться уместными или неприемлемыми. Тем самым идентичность участников коммуникации определяет сферу и содержание их общения. Так, разнообразие этнических идентичностей, являющееся одним из главных оснований межкультурной коммуникации, является одновременно и препятствием для нее. Таким образом, в межкультурной коммуникации культурная идентичность обладает двойственной функцией. Она позволяет коммуникантам составить определенное представление друг о друге, взаимно предугадывать поведение и взгляды собеседников, то есть облегчает коммуникацию. Но в то же время быстро проявляется ее ограничительный характер, в соответствии с которым в процессе коммуникации возникают конфронтации и конфликты. Ограничительный характер культурной идентичности направлен на рационализацию коммуникации, то есть на ограничение коммуникативного процесса рамками возможного взаимопонимания и исключения из него тех аспектов коммуникации, которые могут привести к конфликту [39].

Каждому человеку предстоит жить в обществе, и поэтому социальная интегрированность является чрезвычайно важным фактором его жизни. Любому из нас необходимо определенное умение приспособляться к обществу, иначе индивид обречен на устойчивую неспособность ладить с окружающими, изоляцию, мизантропию и одиночество. Индивидуальное развитие каждого человека начинается с его постепенного вхождения, включения в окружающий мир. С самого раннего детства человек усваивает принятые манеры поведения и образцы мышления до тех пор, пока большинство из них не становятся привычными. Это вхождение в мир происходит путем усвоения индивидом необходимого количества знаний, норм, ценностей, образцов и навыков поведения, позволяющего ему существовать в качестве полноправного члена общества. 
Этот процесс освоения индивидом норм общественной жизни и культуры обозначается в различных гуманитарных науках понятиями «инкультурация» и «социализация». Эти понятия во многом совпадают друг с другом по содержанию, так как оба подразумевают усвоение людьми культурных форм (паттернов, англ, pattern) какого-либо общества. Под последними обычно понимают устойчивые совокупности технологий мышления, поведения, взаимодействия, последовательности действий, построения суждений, различные культурные формулы и символы, отражающие определенные представления о реальности. Поэтому в современной научной литературе понятия «инкультурация» и «социализация» нередко используются как синонимы. Это характерно для той группы исследователей, которые придерживаются широкого понимания термина «культура» как любой биологически ненаследуемой деятельности, закрепленной в определенных результатах. Но большинство ученых, считающих культуру исключительно человеческой характеристикой, отличающей человека от всех других живых существ нашей планеты, считают целесообразным проводить различие между этими терминами, отмечая качественные особенности каждого из них [40].

При более строгом научном понимании термина социализация он предстает как процесс усвоения индивидом культурных норм и социальных ролей, благодаря которому происходит превращение человека в социального индивида. Получая в повседневной практике информацию о самых разных сторонах общественной жизни, человек формируется как личность, социально и культурно адекватная обществу. Таким образом, под социализацией понимается гармоничное вхождение индивида в социальную среду, усвоение им системы ценностей общества, позволяющего ему успешно функционировать в качестве его члена.

Самые простые кросс - культурные исследования показывают, что в разных обществах ценятся разные качества личности. Формирование и развитие принятых в данном обществе качеств личности происходит, как 
правило, путем воспитания, то есть целенаправленной передачи норм и правил достойного поведения от старшего поколения младшему. В каждой культуре исторически сложились свои способы обучения приемлемому поведению. Этнологи и социологи сравнили стили воспитания детей в различных культурах и выделили два противоположных: японский и английский.

В Японии воспитатель чаще обращается к поощрению, нежели к наказаниям. Воспитывать там означает не ругать за то, что уже сделано плохо, a, предвидя плохое, обучать правильному поведению. Даже при очевидном нарушении правил приличия воспитатель избегает прямого осуждения, чтобы не поставить ребенка в унизительное положение. Вместо порицания детей обучают конкретным навыкам поведения, всячески внушая им уверенность, что они способны научиться управлять собой, если приложат соответствующие усилия. Японцы считают, что чрезмерное давление на психику ребенка может дать обратный результат.

С европейской точки зрения, детей в Японии неимоверно балуют. Им ничего не запрещают, лишая тем самым поводов заплакать. Взрослые совершенно не реагируют на плохое поведение детей, словно не замечая его. Первые ограничения начинаются в школьные годы, но вводятся они постепенно. Только в эти годы ребенок начинает подавлять в себе стихийные порывы, он учится вести себя подобающим образом, уважать старших, чтить долг и быть преданным семье. По мере взросления регламентация поведения значительно усиливается [36].

В Англии процесс воспитания основывается на совершенно иных принципах. Англичане считают, что неумеренное проявление родительской любви и нежности приносит вред детскому характеру. Баловать детей — значит портить их. Традиции английского воспитания требуют относиться к детям сдержанно, даже прохладно. Мягкость и нежность они проявляют скорее к животным. Дисциплинирующее воздействие на детей оказывается с самого раннего возраста. Если ребенок мучает кошку или собаку, обижает младшего 
или наносит ущерб чужому имуществу, его ждет суровое и жестокое наказание. Наказывать детей в Англии — право и обязанность родителей.

С детства англичане приучаются к самостоятельности и ответственности за свои поступки. Они рано становятся взрослыми, и для взрослой жизни их не надо специально готовить. Сознательно отстраняясь от детей, родители готовят их к трудностям взрослой жизни. Уже в 16 - 17 лет, получив права и аттестат, дети уезжают из родительского дома и живут независимо [71].

В отличие от социализации понятие инкультурация подразумевает обучение человека традициям и нормам поведения в конкретной культуре. Это происходит в процессе отношений взаимообмена между человеком и его культурой, при которых, с одной стороны, культура определяет основные черты личности человека, а с другой, - человек сам влияет на свою культуру. Инкультурация включает в себя формирование основополагающих человеческих навыков, как, например, типы общения с другими людьми, формы контроля за собственным поведением и эмоциями, способы удовлетворения основных потребностей, оценочное отношение к различным явлениям окружающего мира и т.д. Результатом инкультурации является эмоциональное и поведенческое сходство человека с другими членами данной культуры и его отличие от представителей других культур. По своему характеру процесс инкультурации более сложен, чем процесс социализации. Дело в том, что усвоение социальных законов жизни происходит гораздо быстрее, чем усвоение культурных норм, ценностей, традиций и обычаев.

Несмотря на описанные различия содержательное и смысловое разграничение понятий «инкультурации» и «социализации» до сих пор остается дискуссионным в науке. Так, М. Мид под социализацией понимает социальное научение вообще, а под инкультурацией - реальный процесс научения, происходящий в специфической культуре. Д. Матсумото считает социализацией процессы и механизмы, с помощью которых люди познают социальные и культурные нормы, а инкультурацией - продукты процесса 
социализации. Практически все исследователи сходятся в том, что социализация более универсальна, а инкультурация - культурно - специфична. И, безусловно, процессы инкультурации и социализации неразрывно связаны друг с другом, могут протекать только совместно. Каждый человек в процессе своего индивидуального развития достигает специфичной для данной культуры социализации и общей инкультурации [68].

На протяжении всей своей жизни каждый человек проходит определенные фазы, которые называют стадиями жизненного цикла. Это детство, юность, зрелость и старость. На каждой стадии жизненного цикла процесс инкультурации характеризуется своими результатами и достижениями. В зависимости от этих достижений обычно выделяют две основные стадии инкультурации - начальную (первичную), охватывающую периоды детства и юности, и взрослую (вторичную), охватывающую два других периода.

Первичная стадия инкультурации начинается с рождения ребенка и продолжается до окончания подросткового возраста. Она представляет собой процесс воспитания и обучения детей. В этот период дети усваивают важнейшие элементы своей культуры, овладевают ее азбукой, приобретают навыки, необходимые для нормальной социокультурной жизни. Процессы инкультурации реализуются у них в это время в основном в результате целенаправленного воспитания и частично на собственном опыте. По мнению культурного антрополога Мелвилла Херсковица, ребенок, хотя и не является пассивным элементом инкультурации, но выступает здесь скорее, как инструмент, нежели как игрок. Взрослые, применяя систему наказаний и поощрения, ограничивают его возможность выбора или оценки. Кроме того, дети не способны к сознательной оценке норм и правил поведения, они усваивают их некритично. Дети должны выполнять правила того мира, в котором они живут. Это приводит к тому, что они видят мир в черно - белом цвете и не способны на компромиссы [54]. 
Способы первичной инкультурации зависят от того, к какому полу принадлежит воспитатель. Женщина чаще стремится приласкать ребенка, оградить его от холода, действует поощрением, потакает слабостям и капризам. Мужчина испытывает эмоциональный дискомфорт при тесном контакте с ребенком, действует угрозой наказания, прибегает к жестким методам воспитания. Материнская опека и уход за ребенком развивают в нем эмоциональную зависимость от взрослых, несамостоятельность. Отец поощряет силовые и военные игры, развивающие самостоятельность и собственную активность ребенка. Тем самым первичная инкультурация закладывает основы половой идентификации. Мальчики играют в военные игры, а девочки - в куклы. Мальчиков учат быть смелыми, сильными, деловыми, а девочек мягкими, хозяйственными, заботливыми.

Первичная стадия инкультурации способствует сохранению стабильности культуры, поскольку основным здесь являются воспроизведение уже имеющихся образцов, контроль проникновения в культуру случайных и новых элементов. Разумеется, не следует преувеличивать роль инкультурации в сохранении культурной традиции. Ее результатом может стать как практически полное и безусловное усвоение культуры новым поколением (с небольшими, едва фиксируемыми отличиями между родителями и детьми), так и нарушение культурной преемственности, когда дети вырастают абсолютно непохожими на своих родителей.

Вторичная стадия инкультурации касается уже взрослых людей, так как вхождение человека в культуру не заканчивается с достижением человеком совершеннолетия.

Инкультурация в этот период носит фрагментарный характер и касается только отдельных элементов культуры, появившихся в последнее время. Обычно это какие-либо изобретения и открытия, существенно меняющие жизнь человека, или новые идеи, заимствованные из других культур. 
Отличительной особенностью второй стадии инкультурации является развитие способности человека к самостоятельному освоению социокультурного окружения в пределах, установленных в данном обществе. Человек получает возможность комбинировать полученные знания и навыки для решения собственных жизненно важных проблем, расширяется его способность принимать решения, которые могут иметь значимые последствия как для него, так и для других людей. Он приобретает право участвовать в действиях, которые могут привести к значительным социокультурным изменениям. Ведь взрослые способны к сознательной оценке своих и чужих поступков, а также ценностей и норм культуры. Кроме того, они могут идти на компромиссы, в их картине мира появляется серый цвет. Вторая стадия инкультурации обеспечивает членам общества возможность принять на себя ответственность за экспериментирование в культуре, за внесение в нее изменений различного масштаба. Иными словами, индивид может принимать или отбрасывать то, что ему предлагается культурой. Он получает доступ к дискуссии и к творчеству [50].

Все процессы социального взаимодействия многопланово отражаются в межкультурной коммуникации, их теоретическое и практическое освоение определяет достижение целей и полноту выполнения задач, поставленных в каждом конкретном коммуникативном акте.

Вступление мирового сообщества в XXI век характеризуется сложными и глубокими переменами во взаимоотношениях между государствами. С одной стороны, происходящий процесс глобализации требует упорядочения международных экономических отношений, с другой стороны, все более обостряются противоречия по разрешению социальных и экологических проблем.

Экономические кризисы, крупномасштабные вооруженные конфликты, растущая нищета во многих государствах, рост транснациональной организованной преступности, распространение инфекционных и 
неинфекционных заболеваний, нарушение экологического равновесия планеты требуют незамедлительного принятия совместных усилий как государств и международных организаций, так и активного включения в этот процесс неправительственных организаций, общественных учреждений, транснациональных корпораций и гражданского общества.

В этих условиях особую актуальность приобретает правовое регулирование международных отношений, и прежде всего путем заключения многосторонних международных соглашений, затем неукоснительного их соблюдения участниками.

Добиваться верховенства права в международных отношениях - одна из главнейших задач государств на современном этапе развития международного сообщества [49]. 


\section{2. Стереотипы в межкультурной коммуникации}

Особенности национального и этнического сознания представителей разных культур потенциально могут выступать барьерами межкультурных взаимодействий. Особый интерес в этом контексте представляют следующие аспекты сознания [63]:

- наблюдаемая тенденция к этноцентризму - склонность негативно оценивать представителей другой культуры сквозь призму стандартов собственной;

- стереотипизация этнического сознания, проявляющаяся в формировании упрощенных образов представителей своей и других культур;

- предрассудки как результат селективных (избранных) включений в процесс межкультурных контактов, в том числе чувственного восприятия, негативного прошлого опыта и т.п.

Эти явления особенно важны как потенциальные барьеры межкультурных взаимодействий на первых стадиях интеракции в ситуации неполной информации о личности партнеров. Асимметрия оценок себя и другого, раздвоенность сознания выступает компенсаторным механизмом культуры, не способной к позитивному взаимодействию с другими.

Наблюдаемый этап развития межкультурной коммуникации обуславливает серьезное влияние стереотипизации, ее роль как потенциального барьера взаимодействий. Так что же такое стереотип?

Стереотип - это жесткое, часто упрощенное представление о конкретной группе или категории людей. Поскольку мы вообще склонны к упрощениям, то формируем стереотипы для большей предсказуемости поведения других людей. Эти стереотипы часто имеют негативную природу и основаны на предрассудках и дискриминации. Стереотипы не обязательно являются ложными; обычно они содержат некое зерно истины. Их разделяет значительное количество людей, что в целом способствует их укоренению. 
Стереотипы могут меняться со временем, но их носителям часто бывает трудно избавиться от усвоенных представлений [38].

Типы межкультурной коммуникации. Передача информации возможна с помощью знаков, знаковых систем. В коммуникативном процессе обычно выделяют вербальную и невербальную коммуникацию.

Вербальная коммуникация общения осуществляется посредством речи. Под речью понимается естественный звуковой язык, то есть система фонетических знаков, включающих два принципа - лексический и синтаксический. Речь является универсальным средством коммуникации, так как при передаче информации с ее помощью передается смысл сообщения. Благодаря речи осуществляется кодирование и декодирование информации.

Невербальная коммуникация. Визуальные виды общения - это жесты (кинесика), мимика, позы (пантомимика), кожные реакции (покраснение, побледнение, потоотделение), пространственно-временная организация общения (проксемика), контакт глазами.

Акустическая система, включающая в себя следующие аспекты: паралингвистическую систему (тембр голоса, диапазон, тональность) и экстралингвистическую систему (это включение в речь пауз и других средств, таких как покашливание, смех, плач и др.).

Тактильная система (такесика) (прикосновения, пожатие руки, объятия, поцелуи).

Ольфакторная система (приятные и неприятные запахи окружающей среды; искусственные и естественные запахи человека).

Цели общения отражают потребности совместной деятельности людей. Деловое общение почти всегда предполагает некоторый результат - изменение поведения и деятельности других людей. Общение выступает как межличностное взаимодействие, т.е. связи и влияние, которые складываются в результате совместной деятельности людей.

Выделяют следующие виды взаимодействия [5]:

- групповая интеграция (совместная трудовая деятельность, кооперация), 
- конкуренция (соперничество),

- конфликт.

Для того чтобы общение было эффективным, диалогическим, необходимо соблюдать следующие условия:

- равенство психологических позиций социальных субъектов независимо от их социального статуса;

- равенство в признании активной коммуникативной роли друг друга;

- равенство в психологической взаимоподдержки.

Спецификой взаимодействия является то, что каждый его участник сохраняет свою автономность и может обеспечивать саморегуляцию своих коммуникативных действий.

Р. Бейлз объединил наблюдаемые образцы взаимодействия в четыре глобальных категории, которые фиксируют форму взаимодействия:

\begin{tabular}{|l|l|}
\hline Области взаимодействия & Основные поведенческие проявления \\
\hline Позитивные эмоции & $\begin{array}{l}\text { Выражение солидарности } \\
\text { Снятие напряжения } \\
\text { Выражение согласия }\end{array}$ \\
\hline Решение проблем & $\begin{array}{l}\text { Предложения, указания } \\
\text { Выражение мнений } \\
\text { Выдача ориентаций }\end{array}$ \\
\hline Постановка проблем & $\begin{array}{l}\text { Просьбы об информации } \\
\text { Просьбы высказать мнение } \\
\text { Просьбы об указаниях }\end{array}$ \\
\hline Негативные эмоции & $\begin{array}{l}\text { Выражение несогласия } \\
\text { Создание напряженности } \\
\text { Демонстрация антагонизма }\end{array}$ \\
\hline
\end{tabular}

Невербальное поведение выполняет важные функции в процессе межкультурной коммуникации, однако используемые символы могут иметь различное значение для участников взаимодействия. Их несовпадение может оказывать влияние на эффективность интеракции [49]. 


\section{Языковая личность в межкультурной коммуникации. Оценивая} характеристики личности и их влияние на процессы коммуникации, основными являются формально - личностные признаки, а именно пол, возраст, семейное положение. Есть свои привила в женском, мужском, детском социумах. Помимо этих характеристик существенное влияние на коммуникацию оказывают индивидуальные психологические черты характера.

1. Общительность - выражается в потребности человека контактировать с другими людьми. Общительность определяется типом темперамента.

2. Контактность - способность вступать в психологический контакт и формировать доверительные основанные на взаимном согласии отношения.

3. Коммуникативная совместимость - готовность и умение создать непринужденную атмосферу взаимной удовлетворенности друг другом.

4. Адаптивность - готовность к пересмотру привычных представлений и решений, способность гибко реагировать на меняющиеся обстоятельства.

5. Самоконтроль - самонаблюдение и самоанализ в ситуации общения, которые проводятся с целью достижения социальной адекватности.

6. Самосознание личности - устойчивое свойство индивида направлять внимание на свои собственные внутренние или внешние действия и поступки. Самосознание имеет три аспекта:

- личное самосознание - внешнее к себе и к своим мыслям;

- публичное самосознание - знание о себе как о субъекте восприятия другими людьми;

- социальная тревожность - дискомфорт в присутствии других людей.

В разных культурах эти три аспекта имеют разные приоритеты.

7. Коммуникативное понимание - типичная для каждой личности ориентация на определенный способ общения. Коммуникативное понимание тем выше, чем больше человек склонен к одиночеству, находится в социальной изоляции. Иными словами, люди замкнутые, консервативные, склонные к изоляции чувствуют человека вернее и точнее, чем социально успешные люди [51]. 


\section{Билингвальное образование как часть межкультурной}

коммуникации. Билингвальное обучение позволяет осуществить глубокое проникновение в культуру другого народа, расширяет возможности активного использования иностранного языка, что является предпосылкой успешной адаптации выпускников к условиям общеевропейского рынка.

Актуальность обучения на билингвальной основе как базового компонента углубленного языкового образования определяется, прежде всего, всеобщей мировой тенденцией к интеграции в экономической, культурной и политической сферах, что в образовательной сфере обусловливает тенденцию к интеграции предметного знания, направленности на познание целостной картины мира. С учетом этих тенденций обучение на билингвальной основе обеспечивает учащимся широкий доступ к информации в различных предметных областях, получение новой информации в соответствии с индивидуальными потребностями, возможности непрерывного образования, что в свою очередь создает дополнительные шансы конкурировать на общеевропейском и мировом рынке специалистов. Наряду с этим, обучение на билингвальной основе способствует совершенствованию общей языковой подготовки и владения иностранным языком в специальных предметных целях, углублению предметной подготовки и расширению сферы межкультурного обучения, а также повышению мотивации в изучении иностранному языку. Под терминами двуязычие или билингвизм обычно понимается владение и применение более чем одного языка, причем степень владения тем или иным языком может быть весьма различной. Высшая степень двуязычия возникает тогда, когда говорящий признает родным второй язык. Но идеальные двуязычные билингвы, существование которых П. Блумфильду казалось когда то возможным, на самом деле почти не встречаются. Индивидуальный билингвизм скорее является феноменом, который проявляется, прежде всего, там, где существуют языковые меньшинства. Неодинаково чаще всего и функциональное распределение языков в той или иной сферах. Фактически 
билингвы используют каждый из языков, которыми владеют в различных социальных контекстах и не в состоянии использовать каждый из известных им языков во всех контекстах в равной степени. Когда - то У. Вайнрайх выдвинул также ставшую знаменитой идею о том, что билингвизм может быть составным, когда системы двух языков образуют нечто общее; координативным, когда системы двух языков существуют относительно независимо; субординативным, когда система второго языка постигается сквозь призму первого, который собственно и интересует методистов. Стоит также различать двуязычие, которое называют контактной или «естественной двуязычностью», приобретенное в языковой среде в условиях совместной повседневной жизни двух народов. Например, при длительном проживании за границей, вследствие иммиграции (в более зрелом возрасте, как правило, при посещении языковых курсов), детский билингвизм, когда ребенок уже был рожден в иноязычном пространстве в семье национального меньшинства, в случае интернационального брака родителей. В последних двух случаях естественный или контактный билингвизм имеет, как правило, стихийный характер, овладение вторым/обоими языками происходит бессистемно и неосознанно и навыки говорения на обоих языках могут формироваться как параллельно, так и последовательно (с опорой на доминирующий язык). Такое естественное двуязычие более устойчиво и постоянно, оно передается из поколения в поколение и является языковой основой для изменения языка при скрещивании языков [63].

\section{Вопросы для самоконтроля}

1. Что такое культурная идентичность?

2. Дайте определение понятию социализация личности?

3. В чем заключается взаимосвязь социализации и инкультурации?

4. Назовите стадии инкультурации и дайте им характеристику?

5. Какие типы межкультурной коммуникации существуют? 


\section{ЗАКЛЮЧЕНИЕ}

При освоении материала дисциплины «Теория массовых коммуникаций» одним из методологических оснований является теория культуры, теория массовых коммуникаций и теория межкультурных коммуникаций. Bсе указанные теории объединяются культурологической функцией, смысл которой заключается в ознакомлении с достижениями искусства и культуры, которые формируют осознание обществом не только важности сохранения культурных традиций, преемственности культуры, но и применения достижений культуры в практике массовых коммуникаций. Связано это с тем, что с помощью современной медиакультуры люди узнают особенности различных субкультур и культур. Это способствует взаимопониманию, развивает эстетический вкус, способствует снятию социальной напряженности и, в конечном итоге, способствует интеграции и сплочению общества. С этой функцией взаимосвязано понятие массовой культуры. С учетом основных функций и характеристик массовой коммуникации ее социальная сущность заключается в мощном воздействии на общество в целях интеграции, оптимизации его деятельности, социализации индивида. Поэтому специалисты в сфере массовых коммуникаций должны умело пользоваться потенциалом культуры в целом с тем, чтобы решение самых разных вопросов частного порядка способствовало сплочению общества и устранению рисков социальной напряженности. 


\section{СПИСОК ЛИТЕРАТУРЫ}

1. Аберкромби Н., Хилл С., Тернер Б.С. Социологический словарь. - Издво Казанского университета, 1997.

2. Арнольдов А.И. Введение в культурологию: учебное пособие. - М., 1993.

3. Арнольдов А.И. Социалистическая культура: теория и жизнь. - М.: Политиздат, 1984.

4. Баллер Э.А. Коммунизм. Культура. Человек. - М.: Сов. Россия, 1984.

5. Барулин В. С. Социальная философия. Ч. 2: учебник. - М.: Изд-во МГУ, 1993. - С. 119-122.

6. Белая Е.Н. Теория и практика межкультурной коммуникации. - Омский государственный университет, 2008 - 208 с.

7. Бердяев Н.А. О культуре//Философия неравенства. - М.: ИМАПресс, 1990. - C. 247-261.

8. Бердяев Н.А. О назначении человека. - М.: Республика, 1993. - С. 316.

9. Большая советская энциклопедия. - Т. 24. - М.: Изд-во «БСЭ», 1954. C. 31 .

10. Брайтон К. Оценивание межкультурной коммуникативной компетенции // Педагогическое образование в России. - 2013. - № 1. - С. 207 214.

11. Введение в культурологию: учебное пособие. - М., 1995.

12. Владимирова Т.Е. Призванные в общение. Русский дискурс в межкультурной коммуникации. - M.: URSS: [ЛИБРОКОМ, 2010]. - 299 с.

13. Выжлецов Г.П. Аксиология культуры. - СПб., 1996.

14. Гобозов И. А. Введение в философию истории. - М., 1995. - С. 67.

15. Гришаева Л.И. Введение в теорию межкультурной коммуникации. Учебное пособие для студентов высших учебных заведений. - М.: Академия, 2007. - $331 \mathrm{c}$. 
16. Гуревич П.С. Философия культуры. - 2-е изд. - М., 1995.

17. Гуревич П.С. Философия культуры. - М.: Аспект пресс, 1994. C. 19-39.

18. Давидович В.Е., Жданов Ю.А. Сущность культуры. - Ростовн/Д., 1979.

19. Диалектика деятельности и культура / отв. ред. В.Г. Табачковский, А.И. Яценко. - К.: Наукова думка, 1983.

20. Емельянов С.M. Теория и практика связей с общественностью. Вводный курс: учебное пособие. - СПб., 2006.

21. Ерасов Б.С. Социальная культурология. - М.: Аспект-Пресс, 2000.

22. Ефимов Ю.И., Громов И.А. Человеческий фактор и культура. - М.: Наука, 1989.

23. Зворыкин А.А. Наука, производство, труд. - М.: Наука, 1965.

24. Зинченко В.Г., Зусман В.Г., Кирнозе З.И. Межкультурная коммуникация. - М.: Флинта, 2007 - 224 с.

25. Злобин Н.С. Культура и общественный прогресс. - М.: Наука, 1980.

26. Ильин И. Словарь терминов. Постмодернизм. - М., 2001.

27. Иовчук М.Т., Коган Л.Н. Советская социалистическая культура: опыт и современные проблемы. - М.: Политиздат, 1979.

28. Каган М. С. Человеческая деятельность. - М.: Политиздат, 1974.

29. Кармин А.С. Культурология: учебник. - Изд. 3-е. - СПб.: Питер, 2004.

30. Келле В.Ж., Ковальзон М.Я. Теория и история. - М., 1981. С. 225.

31. Коган Л.Н., Ханова О. В. Культура в условиях НТР. - Саратов: Изд-во Сарат. ун-та, 1987.

32. Красовецкий Н.Д. Социологические основы управления бизнесорганизацией: учебное пособие. - М.: Юнити-Дана, 2007.

33. Кребер А.А. Избранное: природа культуры. - М.: Росспэн, 2004.

34. Кретинина Г. Межкультурная коммуникация и обучение английскому дискурсу // Высшее образование в России. - 2007. - N 8. - С. 135 - 136. 
35. Кривокора Е.И. Деловые коммуникации. - Учеб.пособие. - М.: Инфра, 2011.

36. Культура в свете философии/Н.Э. Чавчавадзе и др. - Тбилиси: Хеловнеба, 1979.

37. Культурная деятельность: Опыт социологического исследования / отв. ред. Л.Н. Коган. - М.: Наука, 1981;

38. Культурология. ХХ век. Словарь. - СПб.: Университетская книга, 1997.

39. Культурология: учеб. пособие. Ростов-н/Д.: Феникс, 1997. - С. 13.

40. Культурология: учеб. пособие/науч. ред. проф. Г.В. Драч. Ростовн/Д.: Феникс, 1997. - С. 86.

41. Культурология: учебное пособие / под ред. А.А. Радугина. - М., 1996.

42. Культурология: учебное пособие для высших учебных заведений/сост. и отв. ред. проф. А.А. Радугин. - М.: Изд-во Центр, 1996. - С. 108-122.

43. Льюис Д. Деловые культуры в международном бизнесе. От столкновения к взаимопониманию. - М.: Дело, 1999. [35]

44. Мамонтов А.С., Мамонтов С. П. Культурология. - М., 2005.

45. Мамонтов А.С., Мамонтов С.П., Морослин П.В., Григорьев Н.Ю. Культурология - учебник для академического бакалавриата. - М.: Издательство Юрайт, 2016.

46. Маркарян Э.С Теория культуры и современная наука (Логикогносеологический анализ). - М.: Наука, 1983.

47. Международный менеджмент / Под ред. С.Э. Пивоварова, Д.И. Баркана, Л.С. Тарасевича. - СПб.: Питер, 2000.

48. Межуев В.М. Культура и история: Проблема культуры в филос.-истор. теории марксизма. - М.: Политиздат, 1977.

49. Минюшев Ф.И. Социология культуры: учебное пособие. - М.: Академический проект, 2004.

50. Михайлов Ф.Т. Самоопределение культуры: Философский поиск. М.: Изд-во Индрик, 2003. 
51. Немировская Л.3. Культурология. История и теория культуры. - М, 1992.

52. О России и русской философской культуре. Философы русского послереволюционного зарубежья. - М.: Наука, 1992.

53. О России и русской философской культуре: Философы русского послеоктябрьского зарубежья. - М., 1990. - С. 44.

54. Оганов А.А., Хангельдиева И.Г. Теория культуры: учебное пособие. М.: Фаир-пресс, 2004.

55. Ойзерман Т.И. Существуют ли универсалии в сфере культуры?//Вопр. философии. - 1989. - № 2. - С. 56.

56. Персикова Т.Н. Корпоративная культура: учебник - М.: Логос, 2011. $286 \mathrm{c}$.

57. Персикова Т.Н. Межкультурная коммуникация и корпоративная культура. - М.: Логос, 2008 - 114 с.

58. Петрий П.В. Духовные ценности российского общества и армия: монография. - М.: ВУ, 2001.

59. Пикуль В.С. Псы господни//Собрание сочинений. - Т. 21. - С. 70.

60. Политология: курс лекций / под ред. М.Н. Марченко. - 2-е изд., перераб. и доп. - М., 1997. - С. 231.

61. Попов В.В. Социология культуры. Курс лекций. - М.: ВУ, 1999.

62. Попов С.Г. Социальный менеджмент. Уч. пособие. - М.: Ось-89, 2009.

63. Проблемы философии культуры: Опыт историкоматериалистического анализа / под ред. В. Ж. Келле. - М.: Мысль, 1984. - С. 63.

64. Риккерт Г. Науки о природе и науки о культуре // Культурология. ХХ век. Антология. - М., 1995. - С. 70.

65. Сагатовский В.Н. Полярность базовых ценностей культуры на рубеже III тысячелетия / «Бренное и вечное»: Ценности культуры в прошлом, настоящем и будущем / Науч. конф. 15-17 окт. 1998 г. - Новгород, 1998. - С. 8. 
66. Сагатовский В.Н. Русская идея: продолжим ли прерванный путь? СПб., 1994.

67. Садохин А.П., Грушевицкая Т.Г. Культурология: Теория культуры. Изд. 2-е, перераб. и доп. - М.: ЮНИОН, 2004.

68. Самохвалова В.И. Культурология. Краткий курс лекций. - М., 2002.

69. Самохина Т.С. Они и мы. Америка, Англия и Россия // http://vocabul.ru/lib/culture/theyandus/

70. Сильвестров В.В. Философское обоснование теории и истории культуры. - М., 1990.

71. Смирнова Г.Е. Особенности историко - ментального развития России и Англии XVIII в. в контексте современных культурологических теорий // Вестник Московского университета. Сер. 19, Лингвистика и межкультурная коммуникация. - 2004. - № 1. - С. 172 - 179.

72. Социологический энциклопедический словарь / ред.-коорд. Г.В. Осипов. - М., 2000.

73. Спиркин А.Г. Философия: учебник. - М.: Гардарика, 1999. - С. 762.

74. Сравнительное изучение цивилизаций / сост. Б. С. Ерасов. - М., 1998. - C. $18-26$.

75. Сравнительное изучение цивилизаций: Хрестоматия/сост., ред. и вступ. ст. Б.С. Ерасов. - М.: Аспект Пресс, 1998.

76. Степин В. С. Личность в технотронную эпоху // Наука в России. 1993. - № 2. - C. 35.

77. Тойнби А.Дж. Цивилизации перед судом истории. - М.: Айрис-Пресс, 2004.

78. Тромпенаарс Ф., Хампден-Тернер Ч. Национально-культурные различия в контексте глобального бизнеса. - М.: Попурри, 2005.

79. Тхорик В.И. Лингвокультурология и межкультурная коммуникация. учебное пособие для студентов высших учебных заведений. - М.: ГИС, 2005. 258 c. 
80. Файнбург 3.И. К вопросу о понятии культуры и периодизации ее исторического развития // Известия Северо-Кавказского центра высшей школы. Общественные науки. 1976. - № 3. - С. 38-39.

81. Философия и культура: XVIII Всемирный философский конгресс: проблемы, дискуссии, суждения / отв. ред. В.В. Мшвениерадзе. - М.: Наука, 1987. - C. $73-78$.

82. Философия: учебник / под ред. В.Д. Губина, Т.Ю. Сидориной, В.П. Филатова. - М.: Русское слово, 1996. - С. 286.

83. Философская энциклопедия. - Т. 3. - М.: Сов. Энциклопедия, 1966. C. 116 .

84. Флоренский П.А. Из богословского наследия//Богословские труды. M., 1977. - C. 127.

85. Черенков В.И. Международный бизнес. Учеб. - метод. комплекс. Р/Д.: Феникс, 2006.

86. Шарков Ф.И. Основы теории коммуникации: учебник. -М.: Перспектива, 2004.

87. Шевченко В. Н. Философия культуры/Очерки социальной философии. - М.: Наука, 1994. - С. 91.

88. Шендрик А.И. Социология культуры: учебное пособие. - М.: ЮнитиДана, 2005.

89. Kroeber A.L. and Kluckholn C. Culture. A Critical Review of Concept and Definitions. - Harvard Univ., 1952.

90. Kaplan D., Manners R. A. Culture Theory. - New York, 1972. 


\section{ГЛОССАРИЙ \\ «КУЛЬТУРА И МАССОВЫЕ КОММУНИКАЦИИ»}

АДАПТАЦИЯ - приспособление самоорганизующихся систем к изменяющимся условиям.

АДАПТАЦИЯ СОЦИОКУЛЬТУРНАЯ (лат. adapto - приспосабливать, прилаживать, устраивать, adaptatio - приспособление) - процесс освоения традиций, норм, обычаев, ценностей; вхождение в другую культуру, принятие ее основополагающих принципов.

АККОМОДАЦИЯ - пассивная форма приспособления к социальным отношениям.

АККУЛЬТУРАЦИЯ - процесс взаимного влияния культур, когда в ходе прямого контакта взаимно усваиваются технологии, образцы поведения, ценности и т.д. Может применяться при анализе социализации, понимаемой как передача элементов культуры от одного поколения к другому в рамках одной культуры.

АКСИОЛОГИЯ - учение о ценностях, исследование содержания, типов, критериев ценностей.

АКТЕР - субъект деятельности, индивид или группа; исполнитель определенных социальных ролей.

АНАЛИЗ КОРРЕЛЯЦИОННЫЙ — статистические методы обнаружения корреляционной зависимости между двумя или более случайными признаками или факторами.

АНАЛИЗ СТРУКТУРНО-ФУНКЦИОНАЛЬНЫЙ - подход в объяснении и описании социальных (социокультурных) систем, при котором исследуются их элементы и зависимости между ними в рамках целого.

АНТРОПОЛОГИЧЕСКИЙ ПОДХОД В КУЛЬТУРЕ — исходит из признания самоценности культуры каждого народа, равноценности всех культур на Земле. 
АПОЛЛОНСКОЕ - ДИОНИСИЙСКОЕ - в социологии культуры основание для выделения двух типов культур (аполлоновское - культура, ориентирующая на ясность, форму и порядок в образе жизни и мировоззрении, дионисийское - культура, ориентирующая на экстатическое, бессознательное и иррациональное).

АРТЕФАКТ - созданный человеком объект; материальное «лицо» культуры.

АРХЕТИП - в позднеантичной философии прообраз, идея; по К.Г. Юнгу - изначальные, врожденные психические структуры, образы, составляющие содержание коллективного бессознательного и лежащие в основе общечеловеческой символики сновидений, сказок и других созданий фантазий, в т.ч. художественной.

АССИМИЛЯЦИЯ - одностороннее либо взаимное поглощение индивидов и групп другими группами, имеющее своим следствием отождествление культурных черт и характеристик самосознания составляющих группы индивидов. В отличие от аккультурации ассимиляция ведет к полной элиминации культурных различий. Формируются маргинальные группы, утратившие связи со старой культурой, но не полностью воспринявшие черты новой культуры.

АУДИТОРИЯ - совокупность лиц, являющихся адресатом общих для всех ее членов средств массовой коммуникации при минимальном или даже вовсе отсутствующем взаимодействии их друг с другом. Аудитория может представлять собой агрегат, например, публика в театре или совокупность изолированных индивидов, например, аудитория телевидения.

БИКУЛЬТУРИЗМ - одновременная принадлежность лица или группы двум культурам (билингвизм, маргинализм).

ВЕРОВАНИЕ - круг устойчивых представлений о сверхъестественном вмешательстве в жизнь людей, беспричинной взаимосвязи жизненных линий и судеб, за которыми лежат человеческие потребности в защите, благосостоянии, 
бессмертии. Понятие «верование» происходит от слова «вера», означающего некритическое восприятие чего-либо - суждения, убеждений, картины мира. Обычно верование связано с трансцендентальными объяснениями фактов социальной и индивидуальной жизни, отнесением их к воле высшего существа. В менталитете любого народа существуют устойчивые представления, например, о жизни души после смерти, переселении душ, страшной суде и т.д., несмотря на то, что абсолютное большинство явлений культуры обязано своим происхождением знанию причинно-следственных связей в мире, здравому смыслу и практической мудрости людей.

ВНУШЕНИЕ (суггестия) — целенаправленное воздействие на личность или группу (массовое внушение), воспринимаемое на уровне подсознания и приводящее либо к появлению определенного состояния духа, чувства, отношение, либо к совершению определенных поступков.

ВООБРАЖЕНИЕ — основанный на использовании имеющегося опыта психический процесс, заключающийся в создании новых представлений, образов и мыслительных комбинаций.

ВПЕЧАТЛЕНИЕ — образ, отражение, след, оставленный в сознании предметами, событиями, мнениями, людьми.

ВЫТЕСНЕНИЕ - защитный механизм психики, состоящий в активном забывании (удалении из сферы сознания в бессознательное) неприемлемых для «Я» влечений и импульсов (в психоанализе - сублимация).

ГУМАНИЗМ - (лат. humanus - человеческий, человечный) признание ценности человека как личности, его право на свободное развитие и проявление своих способностей, утверждение блага человека как критерия оценки общественных отношений. В узком значении - светское вольномыслие эпохи Возрождения, противостоящее религиозной схоластике средних веков.

ДИРЕКТ-МЕДИА - средства личной коммуникации (телефон, почта и др.).

ДИФФУЗИЯ - процесс взаимопроникновения и взаимозаимствования у других культур элементов культуры: речи, письменности, смысловых и 127 
инструментальных ценностей, норм поведения, элементов правосознания, эстетических символов и пр.

«ДИФФУЗНАЯ» КОРПОРАТИВНАЯ КУЛЬТУРА - господство автономных субкультур в корпорации, где размыты основные социокультурные ценности, сформированные в ее штабквартире.

«ДОМИНАНТНАЯ» КОРПОРАТИВНАЯ КУЛЬТУРА - ценностное единство разнообразных «человеческих ансамблей» в разветвленной компании, где автономные субкультуры подразделений дополняют ее исходные ценности.

ДУХОВНАЯ КУЛЬТУРА - прагматически незаинтересованная деятельностная способность человека к созиданию и приобщению к высоким общечеловеческим ценностям.

ДУХОВНОСТЬ - социокультурный феномен, свойственный человеку, группе людей, обществу в целом, основанный на Глоссарий 347 внутренней свободе личности и проявляющийся в высоких нравственных, эстетических, интеллектуальных и религиозных ориентациях.

«ЗАКРЫТАЯ» ОРГАНИЗАЦИОННАЯ КУЛЬТУРА - стереотипная «человеческая» среда компании, где господствуют административнокомандные методы управления, подчиняющие работников «жесткой» культуре ценностных ориентаций топменеджеров.

ИДЕАЛЬНЫЙ ТИП - искусственно логически сконструированное понятие, введенное М. Вебером и необходимое для анализа социальнокультурной реальности через выделение основных черт феномена.

ИДЕОЛОГЕМЫ - принципы регуляции поведения, отраженные в сознании личности как ведущие идеи.

ИДОЛЬ - рукотворные фетиши, материальные предметы, статуи, истуканы, иконы - объекты религиозного поклонения.

ИСКУССТВО - художественное творчество в целом - литература, архитектура, скульптура, живопись, графика, декоративное искусство, музыка, танец, театр, кино и др.; высокая степень умения, мастерства в любой сфере 
деятельности; сфера духовно-практической деятельности людей, которая направлена на художественное постижение и освоение мира и призвана удовлетворять универсальную потребность человека в воссоздании окружающей действительности в развитых формах человеческой чувствительности.

ИСКУССТВО ЭЛИТАРНОЕ - специфические формы искусства, создаваемые в расчете на то, что они будут понятны лишь небольшой группе людей, обладающих особой художественной восприимчивостью.

\section{ИССЛЕДОВАНИЕ МЕЖКУЛЬТУРНОЕ (кросс-культурное)}

сравнительное исследование определенных социальных объектов или явлений в контексте различных культур (или в разных странах) с целью определения как универсальных, так и специфических для данной культуры черт этих объектов.

ИССЛЕДОВАНИЕ НАУЧНОЕ - исследование, направленное на выработку новых знаний и открытие закономерностей; характеризуется объективностью, воспроизводимостью, доказательностью, точностью. Исследование включает: постановку задач, представительный анализ имеющейся информации, условий и методов решения задач данного класса, формулировку исходных гипотез, сбор данных, анализ и обобщение полученных результатов, проверку гипотез, формирование утверждений.

ИСТОРИЧЕСКАЯ ПЕРИОДИЗАЦИЯ КУЛЬТУРЫ - разделение истории культуры на определенные временные отрезки. Периодизация основывается на определенном принципе (формационном, цивилизационном, религиозном и т.д.) и является количественно-временной характеристикой культуры.

ИСТОРИЯ КУЛЬТУРЫ - раздел культурологии, который исследует культуру с опорой на исторические факты и события.

ИМПЕРАТИВ КУЛЬТУРНЫЙ - совокупность институтов и форм культуры, необходимых для выживания любого общества, обеспечивающих удовлетворение жизненно важных потребностей, включающих заботу о молодом поколении, передачу знаний, регулирование конфликтов и т.д. 
КАРНАВАЛ - вид массового народного гулянья с уличными шествиями, театрализованными играми.

КАТАРСИС - по Аристотелю - очищение души посредством сопереживания героям трагедий; по 3. Фрейду — процесс уменьшения или снятия тревоги, конфликта, фрустрации посредством их вербализации и эмоциональной разрядки.

КОНТРКУЛЬТУРА — частный случай субкультуры, имеющий ярко выраженный оппозиционный характер к общепризнанным духовным ценностям и более всего к господствующему типу официальной культуры.

КОММУНИКАЦИЯ — передача информации от источника (коммуникатора) к получателю (реципиенту) посредством определенного канала.

КОММУНИКАЦИЯ КУЛЬТУРНАЯ - процесс взаимодействия между субъектами социокультурной деятельности (индивидами, группами, организациями и т.п.) с целью передачи или обмена информацией посредством принятых в данной культуре знаковых систем (языков), приемов и средств их использования.

КУЛЬТ - один из основных элементов религии; действия, имеющие целью дать видимое выражение религиозному поклонению или привлечь к их совершителям божественные «силы».

КОСМОПОЛИТИЧЕСКОЕ В КУЛЬТУРЕ — различного рода явления, процессы, ценности, относящиеся к сфере культуры, но лишенные определенно выраженных признаков национального своеобразия. Явление, весьма характерное для культуры и искусства модернизма и постмодернизма.

КРИЗИС КУЛЬТУРЫ - разрыв преемственной связи в развитии традиций, обычаев, ценностных ориентаций, угасание или потеря идеалов, отсутствие обнадеживающей перспективы. Очень часто кризис культуры обусловлен резкими переменами, реформами, переворотами в сфере социальнополитической, идеологической жизни общества. 
КУЛЬТУРА - а) совокупность материальных и духовных ценностей, выражающая определенный уровень исторического развития данного общества и человека (цивилизация); б) сфера духовной жизнедеятельности общества, включающая науку, систему образования, воспитания, духовного творчества; в) уровень овладения той или иной областью знаний или деятельности; г) формы социального поведения человека, обусловленные уровнем его воспитания или образования; д) исторически определенный уровень развития общества, творческих сил и особенностей человека, выраженных в типах и формах организации жизни и деятельности людей, в их взаимоотношениях, а также в создаваемых ими материальных и духовных ценностей.

КУЛЬТУРА АНДЕГРАУНДА — катакомбная культура, возникающая в условиях тоталитарного режима, выражающая собой форму резкого социального протеста, категорическое неприятие официальной идеологии и эстетики.

КУЛЬТУРА ИДЕАЛИСТИЧЕСКАЯ (по П.А. Сорокину) — тип культуры, характеризующийся синтезом идеальных и чувственных ценностей, при доминирующей роли первых.

КУЛЬТУРА ИДЕАЦИОННАЯ (по П.А. Сорокину) — тип культуры, где преобладают нематериальные, трансцендентальные, сверхъестественные ценности.

КУЛЬТУРА ОБЩЕНИЯ - качественная характеристика общения, отличающаяся высокой степенью корректности, уважительности, понимания партнеров.

КУЛЬТУРА ОБЩЕСТВА - совокупность доминирующих ценностных образцов сознания и поведения, воспроизводимых и принимаемых данным социумом.

КУЛЬТУРА ТРУДА - качественная характеристика деятельности человека, создающего новые или воспроизводящего существующие материальные или духовные ценности, отличающиеся высоким профессиональным уровнем. 
КУЛЬТУРНАЯ АНТРОПОЛОГИЯ - это систематическая сравнительная наука о культурах обществ, занимающаяся изучением конкретных ценностей, форм связей, опредмеченных результатов культурной деятельности в их динамике, механизмов трансляции культурных навыков от человека к человеку.

КУЛЬТУРА МАССОВАЯ - а) вид культуры современного индустриального общества, характеризующийся производством культурных ценностей, рассчитанных на массовое потребление и распространяемых средствами массовой коммуникации; б) вид культуры, характеризующийся ориентацией на усредненный массовый вкус, стандартизацией формы, содержания, расчетом на коммерческий успех; в) социокультурное явление индустриального общества, характеризующееся упрощенностью, доступностью потребления культурных ценностей широкими слоями населения.

КУЛЬТУРА РЕЧИ - соответствие индивидуальной речи нормам данного языка; раздел языкознания, исследующий проблемы нормализации литературного языка.

КУЛЬТУРА СЕНСИТИВНАЯ (по П.А. Сорокину) - тип культуры, ценности которой ориентированы на улучшение материальных условий жизни.

КУЛЬТУРА ФАУСТОВСКАЯ (по О. Шпенглеру) — западноевропейская культура, характеризующаяся деятельным существованием, непрерывным становлением, устремленностью в будущее, острым переживанием времени, историзмом.

КУЛЬТУРНАЯ УСЛУГА - деятельность, в результате которой создается продукт, способный удовлетворить различные духовные потребности общества и определенных его представителей.

КУЛЬТУРНАЯ ПОЛИТИКА - научно обоснованная деятельность государства, направленная на поддержание и развитие культуры.

КУЛЬТУРА ЯЗЫКА - качественная характеристика, уровень знания, степень освоения языковой системы, способность и умение человека использовать данные языком возможности для адекватного выражения мыслей и чувств. 
КУЛЬТУРНАЯ ЭКСПАНСИЯ - вторжение в культуру, навязывание чуждых ценностей и подчинение себе различных сфер общественной жизни в развивающихся странах.

КУЛЬТУРНОЕ ПОЛЕ - территориально-экономический ареал, включающий всю совокупность характерных для данной среды культурных моделей.

КУЛЬТУРНЫЙ КАПИТАЛ - согласно П. Бурдье, успех в получении образования в значительной степени определяется 352 Глоссарий тем, насколько господствующая культура усвоена индивидами, или тем, каким качеством культурного капитала они обладают. П. Бурдье утверждает, что власть придерживающих контролируют форму, которую принимает культура, оказываясь, таким образом, способным сохранять свое положение.

КУЛЬТУРНАЯ КОММУНИКАЦИЯ - совокупность в общественной жизни процессов передачи информации - идей, представлений, мнений, оценок, знаний, чувств и т.п. - от индивида к индивиду, от группы к группе.

КУЛЬТУРНАЯ РЕВОЛЮЦИЯ - радикальная смена ценностных ориентаций в сфере культуры, обусловленная, как правило, социальнополитическими, идеологическими катаклизмами.

КУЛЬТУРНО - АНАЛИТИЧЕСКИЙ ПОДХОД - концеПция, согласно которой социология рассматривается как наука о культуре и для нее характерно определение общих закономерностей функционирования культуры и общества.

КРОСС-КУЛЬТУРНЫЕ ИССЛЕДОВАНИЯ - изучение влияния различных национальных деловых культур на поведение работников в процессе создания совместных предприятий с разноязычным персоналом.

КУЛЬТУРНЫЕ СУПЕРСИСТЕМЫ - по П.А. Сорокину, это основополагающие фазы развития культуры, опирающиеся на доминирующие в данном обществе ценности; в соответствии с характером доминирующей ценности существуют три типа культурных суперсистем: идеациональный, идеалистический и чувственный.

КУЛЬТУРНЫЙ ШОК - потрясение, испытываемое представителями определенной культуры при соприкосновении с другой культурой. 
КУЛЬТУРОЛОГИЯ - это комплексная наука, изучающая все аспекты функционирования культуры, от причин ее возникновения до различных форм исторического самовыражения.

«КРОСС-КУЛЬТУРНЫЙ ШОК» - состояние растерянности и беспомощности, вызванное потерей обычных ценностных ориентиров и неспособность дать ответы на вопросы: где, когда и как поступать правильно?

«КУЛЬТУРНАЯ РЕВОЛЮЦИЯ» В МЕНЕДЖМЕНТЕ - переосмысление управления поведением работников в американских бизнес-организациях 80-х гг. прошлого века под влиянием более эффективной японской управленческой системы, а также в результате «раскрытия» социокультурных эффектов образцовых американских компаний.

«ОТКРЫТАЯ» ОРГАНИЗАЦИОННАЯ КУЛЬТУРА - уникальная «человеческая» среда компании, в которой господствует вера работников в определенные демократические ценности, регулирующие их поведение в управленческих и деловых ситуациях.

КУЛЬТУРНЫЙ ЦИКЛ - в циклических теориях (О. Шпенглер, А. Тойнби, П. Сорокин) - регулярно повторяющееся фазы развития культуры: рождение, юность, зрелость, старение, смерть.

МАТЕРИАЛЬНАЯ КУЛЬТУРА - совокУпность опредмеченных духовных ценностей. Вещный мир в той мере входит в сферу культуры, в какой является носителем и выразителем духовных ценностей. Предметы, ограниченные функционально-утилитарным назначением, строго говоря, собственно, к культуре отношения не имеют.

МАССОВАЯ КОММУНИКАЦИЯ - систематическое распространение специально подготовленных сообщений, представляющих социальную значимость, среди численно больших, анонимных, рассредоточенных аудиторий с целью оказания влияния на установки, оценки, мнения и поведения людей. 
МЕТОДОЛОГИЯ ИЗУЧЕНИЯ КУЛЬТУРЫ - совокупность методов, способов, приемов, подходов, принципов, применяемых в процессе исследования генезиса типологии культуры, конкретно-исторических, национальных и др. форм ее существования.

МИРОВОЗЗРЕНИЕ — система взглядов и представлений людей в окружающем их объективном мире, его изменении и развитии. Важной частью мировоззрения является система взглядов на функционирование и развитие общества. Выделяют такие стороны мировоззрения людей, как их взгляды на развитие природы и общества, формирующиеся на их основе ценности и ценностные ориентации, а также мотивы социальной деятельности тех или иных субъектов. Речь идет о познавательной, ценностно-ориентировочной и мотивационно-побудительной сторонах мировоззрения.

МИФ - фантастические, символические представления о богах и легендарных героях, сверхъестественных силах, объясняющие происхождение и сущность мира, предназначение человека.

МОЗАИЧНАЯ КУЛЬТУРА - термин, который возник в ХХ в. для характеристики особенностей культуры нетрадиционного типа.

МОРАЛЬ - общественный институт регулирования поведения человека. Форма общественного сознания, элемент духовной культуры.

МОРФОЛОГИЯ КУЛЬТУРЫ - составная часть теории культуры, изучающая основные структурные элементы культуры как сложной целостной системы, принципы их взаимодействия. МОТИВ - движущая сила, повод, побудительная причина. Мотив не определяет действие, он только проявляется «в и через контуры действия» (Ж.П. Сартр). В эстетике мотивом (или сюжетом) называют материал, давший повод художественному изображению.

МОТИВАЦИЯ - система внутренних факторов, вызывающих и направляющих ориентированное на достижение цели поведение человека или животного. Разработано множество часто противоречивых теорий для объяснения того, почему он выбирает именно те действия, которые совершает; почему некоторые люди обладают более сильной мотивацией, чем другие, в 
результате чего добиваются успеха там, где имеющие не меньшие возможности и способности терпят неудачу.

НАУКА - особая область культуры, основной функцией которой является выработка и систематизация общезначимых знаний о мире.

НАУЧНО-ИССЛЕДОВАТЕЛЬСКАЯ ДЕЯТЕЛЬНОСТЬ - ориГИНаЛЬНЫР исследования в области естественных или социальных наук, культуры или образования, предполагающие тщательные, упорядоченные изыскания на основе критического подхода с использованием различных приемов и методов, зависящих от характера и условий поставленных проблем.

НАЦИОНАЛЬНАЯ КУЛЬТУРА - совокупность исторически сложившихся характерных черт, свойств, особенностей, присущих культурной жизни того или иного народа.

НООСФЕРА - сфера взаимодействия природы и общества, где разумная деятельность человека опирается на науку.

НОРМА - а) мера, образец, средняя величина чего-нибудь; б) узаконенное установление, призванный обязательным порядок, строй чегонибудь; в) правило поведения в определенной ситуации; г) форма регуляции поведения в биологии, техники, социальных системах. Отклонение от нормы наказывается санкциями, приобретаются же нормы посредством интернализации и социализации.

НРАВЫ - традиционные стандартные предписания, которые, регулируя поведение отдельных индивидов, поддерживают существование группы в целом.

НРАВСТВЕННАЯ КУЛЬТУРА - характеристика межличностных отношений, способов регуляции поведения и поступков людей на основе моральных норм и идеалов.

ОБЩЕСТВО - социально - культурная система, составными элементами которой являются социальные институты и организации, 
социальные общности и группы, вырабатывающие определенные социальные ценности и нормы.

ОБЩЕСТВО (в культурологическом плане) - система ценностей, передающихся из поколения в поколение и трансформирующихся в сознании индивида в виде общепризнанных норм поведения и способов мышления.

ОБРАЗ КУЛЬТУРЫ - продукт отражения сознания и на уровне социальных общностей, и отдельных индивидов более или менее устойчивых и значимых форм воплощения.

ОБЫЧАЙ — a) распространенный тип поведения, складывающийся в реальной жизни и основанный на принципе повторения. Обычай - социальный образец, общепринятый принцип поведения. Слово «обычай» является однокоренным со словом «обычно», т.е. повседневно, как правило; б) воспринятая из прошлого форма социальной регуляции деятельности и отношений людей, которая воспроизводится в определенном обществе или социальной группе и является причиной определенного поведения его членов. Обычай состоит в неуклонном следовании воспринятым из прошлого предписаниям. В роли обычая могут выступать различные обряды, праздники, производственные навыки т.д. Обычай - это неписанные правила поведения. Термин «обычай» может отождествляться с терминами «традиция», «обряд», «ритуал», «нравы». Однако традиция относится все же к более широкому кругу явлений и применяется к более дифференцированным формам регуляции деятельности, хотя и получает при этом семантическую перегрузку. Обряд и ритуал — более формализованные варианты привычного поведения, принятые в определенных частях совокупной структуры культурной регуляции. Ритуал как формализованное и специализированное поведение служит целям упрочнения связей либо между постоянными членами групп, либо во взаимодействии между группами, снимая напряжение, недоверчивость и повышая уровень коммуникативности. 
ОРИЕНТАЦИЯ ЦЕННОСТНАЯ — разделяемые личностью социальные ценности, выступающие в качестве целей жизни и основных средств их достижения, являющиеся важнейшим фактором, регулирующим, детерминирующим мотивацию личности и ее поведение.

ПАРАДИГМА - проблемное поле исходных противоречий, которое является основой исследовательского поиска.

ПОП-АРТ (сокращенное от англ. popular — общедоступное искусство) направление в современном изобразительном авангардистском искусстве, использующее реальные предметы, изображения, рекламу и т.д., вырванные из реальной среды для создания произвольных комбинаций, и претендующих на общедоступность и массовость.

ПОСТМОДЕРНИЗМ - движение в живописи, литературе, кино, телевидении, в искусстве в целом. Основные черты: а) пастиш - смешение стилевых элементов, заимствованных из совершенно разных контекстов и эпох; б) рефлексивность, способность к самосознанию, часто сопровождающаяся чувством иронии; в) релятивизм, провозглашение отсутствия объективных стандартов истинности; неприятие таких классических художественных приемов, как нарратив (самоповествование объекта) или репрезентация (попытка отображения действительности); г) неуважение к таким традиционным границам в искусстве, как границы между «популярной» и «высокой» культурой, а также границы между различными художественными формами; стремление их преодолеть; д) преуменьшение значимости автора как создателя текста. Пока не понятно, является ли постмодернизм новой культурой.

ПРИКЛАДНАЯ КУЛЬТУРОЛОГИЯ - область научного знания, органично взаимосвязанная с практикой культурной жизни индивидуума, семьи, этноса, региона.

РЕЖИССЕРСКАЯ ПОЗИЦИЯ УПРАВЛЕНИЯ —— ориентация руководителя на формирование системы человеческих отношений в демократическом управлении поведением работников. 
СЕМИОТИКА - дисциплина, исследующая свойства знаков и знаковых систем, как естественных, так и искусственных.

СОЦИОКУЛЬТУРНЫЕ КОЛЛИЗИИ — столкновение противоположных интересов, стремлений и позиций.

СОЦИОКУЛЬТУРНЫЕ ОСНОВЫ МЕНЕДЖМЕНТА - новое направление в развитии теории и практики менеджмента, в котором социальное управление в деловой организации анализируется с позиций существующих ценностей, традиций, норм, правил, убеждений, верований и ритуалов, регулирующих поведение работников.

СОЦИОКУЛЬТУРНЫЕ ПОЗИЦИИ - устойчивые ценностные ориентации определенной группы лиц, регулирующие поведение работников в тех или иных ситуациях привычной деловой жизни.

СОЦИОКУЛЬТУРНЫЙ СИНДРОМ - в широком смысле слова: комплекс уникальных признаков, отличающих одну деловую культуру от других; в узком смысле: комбинация определенных признаков, вычленяющих ту или иную особенность деловой (организационной, корпоративной) культуры в фирме (компании), по которым можно раскрывать и изучать ее социокультурную среду.

СОЦИОКУЛЬТУРНОЕ ПРОТИВОРЕЧИЕ - форма основного противоречия между социальными отношениями и культурой социального субъекта. Она развивается между объективными социальными отношениями (социальным порядком) и массовым жизненным опытом как базисом культуры. Стимулирует напряженное стремление совершенствовать культуру и (или) организацию.

СОЦИОЛОГИЯ КУЛЬТУРЫ - отрасль социологии, изучающая закономерности развития и функционирования культуры в обществе; формирование, хранение, распространение, представление и усвоение идей, культурных норм, ценностей, образцов поведения. 


\section{СОЦИОЛОГИЯ МАССОВЫХ КОММУНИКАЦИЙ — социологическая}

дисциплина, изучающая процессы функционирования и развития средств массовых коммуникаций, а также их социальную обусловленность и последствия их деятельности.

СОЦИОЛОГИЯ МОРАЛИ - отрасль социологии, изучающая закономерности функционирования морали как системы взаимосвязанных норм, ценностей, санкций, оценок, предписаний, образцов поведения.

СОЦИОЛОГИЯ НАУКИ — отрасль социологии, изучающая закономерности функционирования и развития науки как социального института; различные механизмы, обеспечивающие взаимодействие и интеграцию индивидов и социальных групп, участвующих в производстве научного знания; формирование научных сообществ.

СОЦИОЛОГИЯ РЕЛИГИИ — отрасль социологии, изучающая религию как социальный институт во взаимодействии с другими социальными институтами в обществе; проблемы религиозности, секуляризации, психологии верующих.

СОЦИОЛОГИЧЕСКИЙ ПОДХОД (к культуре) - выявляет механизм реализации ценностных ориентаций и их роль в жизни общества, динамику и факторы культурных изменений, влияние культурны на социальные процессы и на различные стороны жизни общества.

СОЦИАЛЬНАЯ АНТРОПОЛОГИЯ - научная дисциплина, которая исследует поведение индивидов, больших и малых социальных групп, принципы регуляции различных сфер социального бытия, а также социальную динамику культуры, представления об эволюции форм социокультурной организации.

СОЦИАЛЬНАЯ КУЛЬТУРОЛОГИЯ - научная дисциплина, которая исследует культурное наследие и социальную память, состояния общественного сознания, генезис и историческую трансформацию духовных образований и социокультурных общностей, включая этнические, национальные, цивилизационные и мировые. 
СОЦИАЛЬНЫЙ ФАКТ - термин, введенный Э. Дюркгеймом для определения образа действия, способного оказывать давление на индивида, и прежде всего через нормы морали и права.

СРЕДСТВА МАССОВОЙ ИНФОРМАЦИИ - эТо технические средства фиксации, копирования, тиражирования, хранения текстов и системного, постоянного распространения целостного потока информации, адресованного массовой аудитории.

СТИГМА - в древности метка или клеймо на теле рабов или преступников; знак бесчестия, налагаемый на индивида другими индивидами или социальными группами; любая негативная санкция или неодобрение чьейлибо нонконформности; стихийное применение моральных санкций через выражение презрения по отношению к нарушителям важных моральных норм, что приводит к их изоляции.

СТРУКТРАЛИЗМ В СОЦИОЛОИИ КУЛЬТУРЫ - концеПция структурного анализа в еe применении к социальным явлениям социокультурного характера.

СТРУКТУРНО-СИМВОЛИЧЕСКИЙ ПОДХОД - направление, согласно которому культура понимается как система знаков и символов, а все процессы, происходящие в ней, рассматриваются как коммуникативные.

СТРУКТУРНО-ФУНКЦИОНАЛЬНЫЙ ПОДХОД - направление исследований, в котором культура и общество рассматриваются как система взаимосвязанных открытых и скрытых функций, определяющих место каждого элемента в системе культуры, а сама культура выделяется как фактор, обеспечивающий устойчивость социальной системы.

СУБКУЛЬТУРА - это набор символов, убеждений, ценностей, норм, образцов поведения, отличающих то или иное сообщество или какую-либо социальную группу. Каждое сообщество создает свою субкультуру. Субкультура не отрицает общечеловеческой культуры, но в тоже время она 
имеет свои специфические отличия, связанные с особенностями жизнедеятельности тех или иных сообществ.

ТАКТ — чувство меры, подсказывающее правильное отношение к комулибо; умение вести себя подобающим образом; соблюдение правил приличия.

ТАЛАНТ — выдающиеся способности, высокая степень одаренности в какой-либо области.

ТВОРЧЕСТВО - деятельность, отмеченная неповторимостью, оригинальностью и общественно-исторической уникальностью.

ТЕХНОКРАТИЯ - направление в общественной мысли, утверждающее, что общество может целиком регулироваться принципами научно-технической рациональности; ее носителями являются техники, инженеры и ученные (технократы), к которым от предпринимателей и политиков должна перейти власть на предприятиях и в обществе в целом.

ТЕОРИЯ КУЛЬТУРЫ - радел культурологи, предметом исследования которого являются общие закономерности развития культуры и специфические закономерности ее становления.

ТРИБАЛИЗМ (трайбализм) - приверженность культурно-бытовой, культовой и общественно-политической племенной обособленности; проявляется межплеменной вражде в африканских странах.

ФЕТИШИЗМ - одна из древнейших форм первобытной религии, основанная на вере в сверхъестественную силу неодушевленных предметов.

ФОЛЬКЛОР — а) традиционные верования, обычаи, легенды, песни, танцы, искусство народа, которые передаются от поколения к поколению; б) все, что имеет отношение к народному творчеству, носящее народный характер.

ФИЛОСОФИЯ КУЛЬТУРЫ - дисциплина, которая исследует концепции происхождения и функционирования культур; это совокупность теоретических подходов, к изучению сущности, цели и ценности культуры, ее условий и форм проявления. 
ФИЛОСОФСКИЙ ПОДХОД (к культуре) - выявляет определенные закономерности в функционировании общества, с помощью которых устанавливаются причины зарождения культуры, особенности ее развития.

ХУДОЖЕСТВЕННАЯ КРИТИКА - область творчества на грани искусства и науки. Занимается истолкованием произведений искусства.

ХУДОЖЕСТВЕННАЯ КУЛЬТУРА - исторически детерминированная система конкретно-чувственного, образного познания мира, закрепления его в художественных ценностях, накапливаемых в виде художественных произведений.

ЦЕННОСТИ - это предметы и явления материального и духовного порядка, их свойства, имеющие социокультурный смысл и предназначение, способные удовлетворить материально-физические и духовные потребности людей, составляющие основу, цель и средство социального развития.

ЦЕННОСТНАЯ СИСТЕМА - модеЛЬ ценностей общества или групп, в которой индивидуальные ценности взаимосвязаны таким образом, чтобы каждая из них усиливала другую и тем самым формировалось бы согласованное целое.

ЦЕННОСТЬ - особое общественное отношение, благодаря которому потребности и интересы индивида или социальной группы переносятся на мир вещей, предметов, духовных явлений, придавая им определенные социальные значимости, не связанные прямо с утилитарным назначением этих вещей, предметов, духовных явлений.

ШАГ НОВИЗНЫ - элемент культуры, определяющий величину допустимых новшеств, не нарушающих комфортное состояние субъекта.

ЭЛИТАРНАЯ КУЛЬТУРА - культура привилегированных групп общества, характеризующаяся принципиальной закрытостью, духовным аристократизмом и ценностно-смысловой самодостаточностью. 
УЧЕБНОЕ ИЗДАНИЕ

Григорьев Николай Юрьевич Мулина Наталья Алексеевна

Чвякин Владимир Алексеевич

\section{КУЛЬТУРА И МАССОВЫЕ КОММУНИКАЦИИ}

\section{Учебник}

Формат 60x84 1/16. Усл. печ. л. 8,31.

МЦНП «Новая наука»

185002, г. Петрозаводск

ул. С. Ковалевской д.16Б помещ. 35

office@sciencen.org

www.sciencen.org

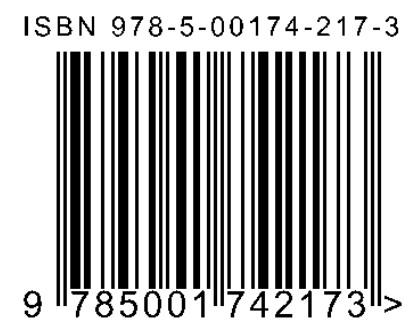




\section{HOBAЯ HAYKA $\because$ NEW SCIENCE Международный центр

www.sciencen.org

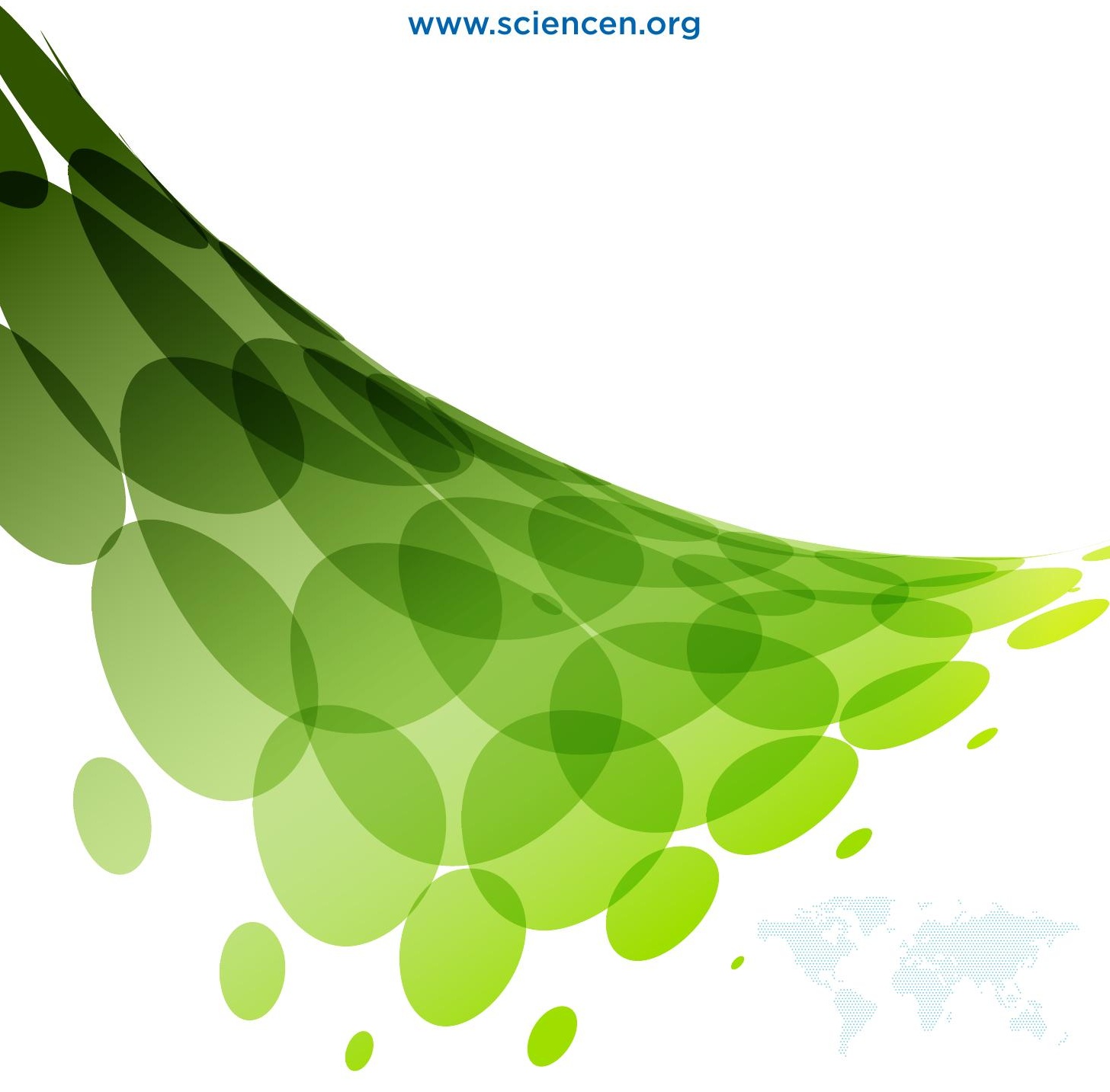

